\title{
Vertical Integration and Media Regulation in the New Economy
}

\author{
Christopher S. Yoo ${ }^{\dagger}$
}

Recent mergers and academic commentary have placed renewed focus on what has long been one of the central issues in media policy: whether media conglomerates can use vertical integration to harm competition. This Article seeks to move past previous studies, which have explored limited aspects of this issue, and apply the full sweep of modern economic theory to evaluate the regulation of vertical integration in media-related industries. It does so initially by applying the basic static efficiency analyses of vertical integration developed under the Chicago and post-Chicago Schools of antitrust law and economics to three industries: broadcasting, cable television, and cable modem systems. An empirical analysis reveals that the structural preconditions recognized by both Schools as necessary for vertical integration to harm competition do not exist in any of these industries. In addition, the cost structure of these industries suggests that vertical integration may well lead to efficiencies sufficient to justify allowing such integration to occur.

A dynamic efficiency analysis provides additional reasons for believing that attempts to regulate vertical integration in these industries are misguided. Growing reliance on compelled access to redress the problems purportedly caused by vertical integration threatens to dampen investment incentives in technologically dynamic industries in which such incentives are particularly important. Not only does forcing a monopolist to share an input deviate from the system of well-defined property rights needed to promote efficient levels of investment, it also deprives new entrants seeking to compete directly with the supposed monopoly bottleneck of their natural strategic partners. The Article also engages a complex web of arguments involving the extent to which technological innovation is affected by market concentration, standardization, and network externalities. A close review of the economic literature reveals

\footnotetext{
$\dagger \quad$ Assistant Professor of Law, Vanderbilt University Law School. This Article benefited immensely from a workshop conducted while I was serving as a Fellow for the Center for Communications Law and Policy at the University of Southern Califormia Law School, as well as a workshop at the 2000 Annual Meeting of the Southeastern Association of American Law Schools. I would also like to thank Ash Bhagwat, Tim Brennan, Andy Daughety, Paul Edelman, Luke Froeb, John Goldberg, Ron Krotoszynski, Mark Lemley, Ed McCaffrey, Bob Rasmussen, Jennifer Reinganum, Jim Speta, Matt Spitzer, Eric Talley, Randall Thomas, Bob Thompson, Mark Weinstein, and Phil Weiser for their helpful comments on earlier drafts of this Article, as well as Rob Mahini, Rob Schmoll, and Paul Wemer for their expert research assistance. I should also disclose that I served as a law clerk for the courts that decided State Oil Co. v. Khan, 522 U.S. 3 (1997), and Time Warner Entertainment Co. v. FCC, 93 F.3d 957 (D.C. Cir. 1996). The views contained in this Article are my own, as are any errors.
} 
that the relationship between these factors is too ambiguous to support the type of simple policy inference needed to prohibit vertical integration as a regulatory matter. The Article concludes with an analysis of the intellectual and institutional obstacles for adopting a more integrated economic approach to vertical integration in these industries.

Introduction

I. The Chain Broadcasting Rules and the Basic Economics of Vertical Integration

A. The Chain Broadcasting Rules: Context,

Substance, and Rationale.

1. The Structure of the Broadcasting Industry

2. The Chain Broadcasting Rules

3. The Economic Theory Underlying the Chain

Broadcasting Rules

B. The Basic Economics of Vertical Integration

1. The Chicago School's Rejection of Per Se

Illegality

2. The Post-Chicago School's Rejection of Per

Se Legality

C. Applying the Basic Economic Framework to the

Chain Broadcasting Rules

1. Concentration in the Market for Television

Networks

2. Concentration and Barriers to Entry in the Market for Home Delivery of Television

Programming.

3. Potential Efficiency Justifications

D. The Future of the Chain Broadcasting Rules

II. The 1992 Cable Act and the Dynamic Inefficiency of Compelled Access

A. Description of the Cable Industry and the

Regulatory Restrictions on Vertical Integration.

1. The Structure of the Cable Industry

2. Provisions of the 1992 Cable Act Affecting

Vertical Integration

3. The Economic Theory Underlying the

Restrictions on Vertical Integration

Contained in the 1992 Cable Act

B. Structural Market Conditions

1. Concentration in the Market for MVPDs 
Vertical Integration and Media Regulation in the New Economy

2. Concentration and Barriers to Entry into the Market for Television Networks .......................................230

3. Potential Efficiency Justifications for Vertical Integration in the Cable Industry........................2232

4. The Special Problem of Rate Regulation ..........................2237

5. Empirical Evidence on Vertical Integration in the Cable Industry ...............................................................2. 238

C. The Problematic Nature of Compelled Access ....................... 243

1. The Relationship Between Compelled Access and Leveraging and Foreclosure

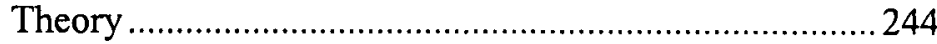

2. The Administrability of Compelled Access.....................244

3. Compelled Access and Dynamic Efficiency....................246

D. The Future of the Vertical Integration Provisions of the 1992 Cable Act........................................................... 247

III. Open Access to Cable Modem Systems and the New Economy Theories of Technological Change................................... 248

A. The Cable Modem Industry and the Open Access

Debate.

1. The Structure of the Cable Modem Industry....................250

2. Regulatory Consideration of Open Access ......................2251

3. The Economic Theory Underlying the Open

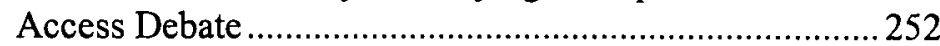

B. Structural Market Conditions ................................................... 253

1. Concentration in the Market for Broadband Transport

2. Concentration and Barriers to Entry into the Market for ISPs.

3. Potential Efficiencies from Combining Cable Modem and ISP Services ................................................260

4. Post-Chicago Models of Open Access .............................2265

5. The Empirical Evidence on Open Access .........................267

C. The Problematic Nature of Compelled Access as a

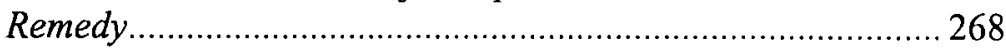

D. The New Economy Arguments: The Effect of

Standardization on Innovation.

1. The Tradeoff Between Standardization and Product Diversity

2. The Relationship Between Market

Concentration and Innovation

3. Network Externalities and Vertical Competition. 
IV. Obstacles to an Integrated Approach to Vertical Media Regulation

A. Misplaced Focus on Technological Differences

Rather than Functional Similarities.

B. Lack of a Comprehensive Approach to the

Economics of Vertical Integration.

C. Misconceived Analogies to Previous Legacy

Monopolies

Conclusion

Introduction

The megamerger between America Online and Time Warner almost unquestionably represented a watershed moment in business history. Not only did it represent the largest merger the world had seen to date, ${ }^{1}$ the combination of Internet content and transmission under the same corporate umbrella threw the already turbulent telecommunications industry into further turmoil. The merger forced all industry players to reevaluate their business plans and prompted speculation about what other mergers might follow. ${ }^{2}$

As dramatic as the merger's impact on the business environment was, the merger's impact on the regulatory environment may have been even greater in that it breathed new life into one of the more hotly debated issues in media policy: "open access" to high-speed broadband systems. ${ }^{3}$ Until recently, most individuals connected to the Internet via narrowband technologies, which employ conventional telephone lines to convey Internet content at speeds no greater than fifty-six thousand bits per second $(56 \mathrm{kbps})$. The last several years have witnessed the arrival of broadband services, which are mainly provided via cable television systems through cable modems and or via a special telephone-based technology known as digital subscriber lines ("DSL"). These new means of transmission represent a major technological leap forward, allowing users to receive

1 At the time the deal was announced, it was valued at over $\$ 150$ billion. Martin Peers et al., Media Blitz: AOL, Time Warner Leap Borders to Plan a Mammoth Merger, WALL ST. J., Jan. 11, 2000 , at $\mathrm{A} 1$. By the time the merger was consummated, its value had shrunk to around $\$ 100$ billion, Jill Carroll, AOL-Time Warner Merger Clears FCC, WALL ST. J., Jan. 12, 2001, at A3, and the deal had been eclipsed by Vodafone's acquisition of Mannesmann, Philip Shishkin \& William Boston, Vodafone Wins EU Clearance to Acquire Mannesmann in Record \$180 Billion Deal, WALL ST. J., Apr. 13, 2000, at A14.

2 See Bruce Orwall \& John Lippman, High Concept in Hollywood: More Web Alliances for Hollywood, WALl ST. J., Jan. 12, 2000, at B1; Susan Pulliam \& Paul M. Sherer, Anything Goes! After AOL Time Warner, Who's Next?, WALL ST. J., Jan. 11, 2000, at C1.

3 For a complete discussion of the regulatory history of open access, see infra Subsection III.A. 2. 
Internet content at speeds exceeding one million bits per second (1 Mbps). The Federal Communications Commission ("FCC") estimates that within the next four years, over one-third of all U.S. households will subscribe to some form of broadband service. ${ }^{4}$

The concern about open access stems from one important difference between narrowband and broadband connections to the Internet. In the narrowband world, customers can use their telephone lines to connect to any one of a large number of Internet service providers ("ISPs"). Broadband providers, in contrast, typically require their customers to employ a proprietary ISP. ${ }^{5}$ Competitors and observers began to raise concerns that such exclusivity arrangements had the potential to reduce consumer choice and harm competition. As a result, these parties asked the FCC to impose an "open access" requirement that would require cable modem systems to make their transmission lines available to other, nonproprietary ISPs on reasonable and non-discriminatory terms. ${ }^{6}$

Early calls for open access fell on deaf ears. Consistent with its longstanding policy of non-regulation of computer-based services, ${ }^{7}$ the FCC rejected calls for imposing open access as a condition to approving AT\&T's acquisition of TCI and MediaOne. ${ }^{8}$ Attempts to impose open access through municipal regulation were effectively blocked by a series of judicial decisions holding that the FCC has exclusive jurisdiction over the issue. ${ }^{9}$ Just seven months after its most recent refusal to impose open access, however, the FCC reversed course and embraced the concept of open access by conditioning its approval of the AOL-Time Warner merger on the merged company's willingness to negotiate access agreements with

4 Inquiry Concerning the Deployment of Advanced Telecomms. Capability to All Americans in a Reasonable and Timely Fashion, and Possible Steps to Accelerate Such Deployment Pursuant to Section 706 of the Telecomms. Act of 1996, 15 F.C.C.R. 20,913, 20,983, ๆ $186(2000)$ (Second Report) [hereinafter Second Advanced Services Report].

5 For example, before its collapse, Excite@Home, which was the largest ISP serving cable modem subscribers, was owned by such major cable modem providers as AT\&T, Comcast, Cox Communications, Cablevision Systems, and Shaw Cablesystems, and was the exclusive ISP for those systems. Time Warner, which is the second largest high-speed broadband provider, has previously required all of its users to use a proprietary ISP called RoadRunner. See Applications for Consent to the Transfer of Control of Licenses and Section 214 Authorizations from MediaOne Group, Inc., Transferor, to AT\&T Corp., Transferee, 15 F.C.C.R. 9816, 9863, I 107 (2000) (Memorandum Opinion and Order) [hereinafter AT\&T-MediaOne Merger].

6 Applications for Consent to the Transfer of Control of Licenses and Section 214 Authorizations from Tele-Communications, Inc., Transferor, to AT\&T Corp., Transferee, 14 F.C.C.R. 3160, 3197-98, I 75 (1999) (Memorandum Opinion and Order) [hereinafter AT\&T-TCI Merger]; AT\&T-MediaOne Merger, supra note 5, at 9866, ๆT 114-15.

7 See, e.g., Jason OXMAN, THE FCC AND THE UNREgulation OF THE INTERNet 8-12 (FCC Office of Plans and Policy, Working Paper No. 31, July 1999), available at http://www.fcc.gov/ Bureaus/OPP/working_papers/oppwp31.pdf.

8 AT\&T-TCI Merger, supra note 6, at 3205-07, 19 92-96; AT\&T-MediaOne Merger, supra note 5 , at $9866-73$, q9 $116-28$.

9 See MediaOne Group, Inc. v. County of Henrico, 257 F.3d 356 (4th Cir. 2001); AT\&T Corp. v. City of Portland, 216 F.3d 871 (9th Cir. 2000). 
at least three unaffiliated ISPs. ${ }^{10}$ The breadth of the reasoning contained in its Memorandum Opinion and Order regarding the merger suggest that the FCC may be willing to consider far more sweeping action. ${ }^{11}$

This abrupt change in policy sparked new regulatory and academic interest in open access. Not only did the FCC's decision place new importance on the Notice of Inquiry currently pending before the agency, ${ }^{12}$ it also stimulated a new round of scholarship that raised two different types of arguments in favor of open access. The first set of arguments centered on the concern that cable modem systems would use vertical integration or other forms of exclusive dealing to harm competition in the market for ISPs. ${ }^{13}$ In so arguing, these scholars invoked one of the central issues of vertical integration theory-whether a company can use its monopoly power over one level of the chain of production to harm competition in another level that otherwise would have been competitive. The danger that media companies might exercise market power vertically has long been a major focus of federal media policy, having played a pivotal role in the seminal cases regarding the structural regulation of broadcasting ${ }^{14}$ and cable television. ${ }^{15}$

The other set of arguments added a distinctively "New Economy" twist to the debate. For example, Professors Mark Lemley and Lawrence Lessig, who are without question two of the leading legal scholars on law and technology issues, contend that open access is essential to preserving and promoting continued innovation on the Internet. ${ }^{16}$ Other scholars have employed such new economic tools as game theory ${ }^{17}$ and network economics $^{18}$ to fashion arguments in support of open access that go far

10 Applications for Consent to the Transfer of Control of Licenses and Section 214 Authorizations by Time Warner, Inc. and America Online, Inc., Transferors, to AOL Time Wamer Inc., Transferee, 16 F.C.C.R. 6547, 6590, \$ 96 (2001) (Memorandum Opinion and Order) (hereinafter AOL-Time Warner Merger]. In so concluding, the FCC endorsed a similar conclusion drawn by the Federal Trade Commission. See America Online, Inc., Docket No. C-3989, 2001 WL 410712 (F.T.C. Apr. 17, 2001) (Decision and Order).

11 AOL-Time Warner Merger, supra note 10, at 36-57, भा 81-127.

12 See Inquiry Conceming High-Speed Access to the Intemet Over Cable and Other Facilities, 15 F.C.C.R. 19,287 (2000) (Notice of Inquiry).

13 See, e.g., Jim Chen, The Authority to Regulate Broadband Internet Access over Cable, 16 BERKEI.EY TECH. L.J. 677 (2001); Jerry A. Hausman et al., Residential Demand for Broadband Telecommunications and Consumer Access to Unaffiliated Internet Content Providers, 18 YALE J. ON REG. 129 (2001); Daniel L. Rubinfeld \& Hal J. Singer, Open Access to Broadband Networks: $A$ Case Study of the AOL/Time Warner Merger, 16 BERKELEY TECH. L.J. 631 (2001). For a detailed review of these arguments, see infra notes 310-322 and accompanying text. $42-49$.

14 NBC v. United States, 319 U.S. 190 (1943). See generally infra text accompanying notes

15 Turner Broad. Sys., Inc. v. FCC, 520 U.S. 180 (1997); Turner Broad. Sys., Inc. v. FCC, 512 U.S. 622 (1994). See generally infra text accompanying notes 209-214.

16 Mark A. Lemley \& Lawrence Lessig, The End of End-to-End: Preserving the Architecture of the Internet in the Broadband Era, 48 UCLA L. REV. 925 (2001).

17 See Rubinfeld \& Singer, supra note 13, at 655-57.

18 See Hausman et al., supra note 13, at 161-65. 
beyond any of the rationales advanced in prior debates about vertical integration in media-related industries. ${ }^{19}$

To date, no one has undertaken a comprehensive evaluation of the economic arguments surrounding these issues. Media scholars have historically analyzed the problems associated with vertical integration in largely non-economic terms. ${ }^{20}$ It is only in recent years that scholars have begun to bring the insights of the burgeoning economic literature on vertical integration to bear on the regulation of media industries. ${ }^{21}$ While providing a welcome and useful starting point for exploring these issues, these initial economic studies have ultimately proven to be somewhat incomplete in that they have either limited their focus to a single communications technology or have concentrated only on certain economic schools of thought without taking the full sweep of modern vertical integration theory into account. The need to come to grips with the full range of issues raised by the literature on vertical integration is likely to grow even more onerous in the near future. As Professors Joseph Kearney and Thomas Merrill have observed, calls for open access in the communications sector are part of a new emerging paradigm that they

19 This Article focuses solely on the economics unique to media-related industries. As a result, I do not discuss telephone-related technologies, which tend to be natural monopolies and which do not require large, up-front sunk costs in content. In so doing, I do not mean to suggest that vertical integration in the telephone industry is unimportant. On the contrary, it is now well-known that such concerns underlay the 1982 breakup of AT\&T, see United States v. AT\&T Co., 552 F. Supp. 131 (D.D.C. 1982), aff'd, 460 U.S. 1001 (1983), as well as the provisions of the Telecommunications Act of 1996 that prohibited the former Bell Operating Companies that did not yet face local competition from entering the long distance market, see 47 U.S.C. $\$ 271$ (Supp. III 1997). For insightful discussions of the continuing influence of concerns about vertical integration on current telephone policy, see Timothy J. Brennan, Does the Theory Behind U.S. v. AT\&T Still Apply Today?, 40 ANTITRUST BULL. 455 (1995); and Paul L. Joskow \& Roger G. Noll, The Bell Doctrine: Applications in Telecommunications, Electricity, and Other Network Industries, 51 STAN. L. REV. 1249 (1999)

20 Most analyses have focused on whether vertical structural regulations violate the First Amendment. E.g., Thomas G. KRattenmaker \& LuCaS A. Powe, JR., Regulating BroadCast PRogrammING (1994); Benjamin M. Compaine, The Impact of Ownership on Content: Does It Matter?, 13 CARDOZO ARTS \& ENT. L.J. 755 (1995); Jonathan W. Emord, The First Amendment Invalidity of FCC Ownership Regulations, 38 CATH. U. L. REV. 401 (1989).

21 See DAVID WATERMAN \& ANDREW A. WEISS, VERTICAL INTEGRATION IN CABLE TELEVISION (1997); Ashutosh Bhagwat, Unnatural Competition?: Applying the New Antitrust Learning to Foster Competition in the Local Exchange, 50 HASTINGS L.J. 1479 (1999); Jim Chen, The Last Picture Show (On the Twilight of Federal Mass Communications Regulation), 80 MINN. L. REV 1415 (1996); David D. Haddock \& Daniel D. Polsby, Bright Lines, the Federal Communications Commission's Duopoly Rule, and the Diversity of Voices, 42 FED. COMM. L.J. 331 (1990); John E Lopatka \& William H. Page, Internet Regulation and Consumer Welfare: Innovation, Speculation, and Cable Bundling, 52 HASTINGS L.J. 891 (2001); John E. Lopatka \& Michael G. Vita, The Must-Carry Decisions: Bad Law, Bad Economics, 6 SUP. CT. ECON. REV. 61 (1998); James W. Olson \& Lawrence J. Spiwak, Can Short-Term Limits on Strategic Vertical Restraints Improve Long-Term Cable Industry Market Performance?, 13 CARDOZO ARTS \& ENT. L.J. 283 (1995); James B. Speta, Handicapping the Race for the Last Mile?: A Critique of Open Access Rules for Broadband Platforms, 17 YALE J. ON REG. 39 (2000) [hereinafter Speta, Handicapping]; James B. Speta, The Vertical Dimension of Cable Open Access, 71 U. CoLO. L. REV. 975 (2000) [hereinafter Speta, Vertical Dimension]. 
believe is effecting a "grand transformation" in the way that policy makers are approaching all regulated industries. ${ }^{22}$

As a result, I believe that the time has come to undertake a more systematic review of the economics of vertical integration and access regimes in order to explore the extent to which the insights provided support or undercut recent attempts to regulate the vertical market structure of the various media industries. ${ }^{23}$ Only by bringing together all of the various threads of vertical integration theory can we understand the way that the different parts of the theory interact with one another.

The basic organization of this Article is to use the major conceptual strands in the economic literature on vertical integration to analyze previous attempts to regulate vertical integration in three different segments of the communications universe-broadcasting, cable television, and high-speed broadband. Part I uses the FCC's first attempt to address the issues raised by vertical integration-the Chain Broadcasting Rulesto review the basic economics of vertical integration. ${ }^{24}$ Even the most cursory reading of the economic literature reveals that issues surrounding vertical integration have proven to be quite controversial, as the Harvard School approach to industrial organization, which tended to regard vertical integration as illegal per se, gave way to the Chicago School of antitrust law and economics, which tended to regard vertical integration as more benign. The Chicago School's call for treating vertical integration as legal per se has in turn inspired the development of the post-Chicago School,

22 See generally Joseph D. Kearney \& Thomas W. Merrill, The Grand Transformation of Regulated Industries Law, 98 COLUM. L. REV. 1323, 1340-57 (1998).

23 This Article is the first step in what I hope will be a comprehensive critique and reconceptualization of media regulation. Previous scholarship in this area has tended to take each medium as a universe unto itself. As a result, policy debates tended to focus on the economics associated with the particular means of transmission at issue and the First Amendment implications of the communications being transmitted. Technological convergence, however, is altering media economics in fundamental ways that make the previous technological orientation untenable. My longterm goal is to begin thinking about media regulation in a more integrated manner by examining the major regulatory approaches taken with regard to each of the existing communications technologies and determining the extent to which the lessons contained in each can serve as a model of regulation for the others. This Article focuses on the characteristic that $I$ believe dominates the approach to regulating cable television (i.e., concerns about the vertical exercise of market power). Subsequent papers will focus on the common carriage and scarcity/diversity paradigms associated with telephony and broadcasting.

24 As scholars have frequently noted, firms can achieve many of the same benefits through vertical contractual restraints. As a result, the insights are quite similar. See ROGER D. BLAIR \& DAVID L. KASERMAN, LAW AND ECONOMICS OF VERTICAL INTEGRATION AND CONTROL 20, 82 (1983); Oliver E. Williamson, Markets \& HierarChies 29-30, 35-37 (1975); Andy M. Chen \& Keith N. Hylton, Procompetitive Theories of Vertical Control, S0 HASTINGS L.J. 573, 583-85, 587, 590-91 (1999). For more detailed analysis of the extent to which vertical restraints can simulate vertical integration, see BLAIR \& KASERMAN, supra, at 52-82; PAUL MILGROM \& JOHN ROBERTS, ECONOMICS, ORGANIZATION AND MANAGEMENT 552-69 (1992); and JEAN TIROLE, THE THEORY OF INDUSTRIAL ORGANIZATION 173-81 (1988). 
which has renewed scholarly interest in the ways that vertical integration can harm competition.

Although the scope of disagreement among these approaches remains significant, what I find most interesting is the extent to which consensus exists on certain issues. In particular, a review of the literature reveals that the Chicago School and post-Chicago models both begin from the premise that certain structural conditions must exist before vertical integration can pose any threat to competition. Furthermore, Chicago School and postChicago theorists generally agree that vertical integration may lead to efficiencies that may justify vertical integration even when the market structure creates some anti-competitive dangers. An application of this basic framework to the broadcast television industry suggests that the emphasis on preventing vertical integration is fundamentally misguided since the relevant markets are not structured in a way that would permit any firm to use vertical integration to harm competition. The analysis shows, moreover, that the cost structure of producing television programming is such that vertical integration is likely to lead to the realization of significant efficiencies. While it is true that game theory, network economics, and innovation-based models do indicate that vertical integration can sometimes harm competition, a close analysis of the formal models reveals that such anti-competitive effects arise only under particular circumstances. As a result, although these analyses provide strong support for rejecting the Chicago School's call for treating vertical integration as legal per se and insisting that vertical arrangements remain subject to antitrust scrutiny under the rule of reason, they do not support the imposition of categorical regulatory rules that would, in essence, render vertical integration illegal without any analysis of the facts of a particular case. Such an outcome would be tantamount to a return to the rule of per se illegality associated with the now-discredited Harvard School approach.

Part II uses an analysis of vertical integration in the cable television industry to extend the analysis further. In addition to applying the framework developed in Part 1, this Part also discusses the problematic nature of compelled access as a remedy. Unlike conventional antitrust remedies, which seek to break up the monopoly power, access remedies simply demand that the monopoly bottleneck be shared, a result that does not necessarily lead to the reductions in price and increases in quantity required to enhance static efficiency. Access remedies cause even greater problems in terms of dynamic efficiency. The central problem is that forcing a monopolist to share an input rescues other firms seeking access to that input from having to develop alternative sources of supply. Access remedies thus can entrench the existing monopoly by depriving firms interested in competing with the monopoly of their natural strategic 
partners. As a result, the economic literature cautions against compelling access whenever the bottleneck resource is available from another source, even if it is only available at significant cost and in the relatively long run. This is particularly true in technologically dynamic industries in which the prospects of developing new ways either to circumvent or to compete directly with the bottleneck are the highest.

Part III employs the lens of the open access debate to add another layer to the economic analysis. In addition to applying the analytical frameworks developed in the previous parts to the problem of open access to cable modem systems, this Part will respond to the New Economybased arguments raised by Professors Lemley, Lessig, and others that restrictions on vertical integration are necessary to preserve and promote technological innovation. In particular, it examines a complex web of arguments involving the extent to which innovation is affected by market concentration, standardization, and network externalities. A close review of the economic literature on these subjects reveals that these arguments are considerably more ambiguous than open access advocates would have us believe. While the sensitivity of these theories to the factual context might possibly provide support for prohibiting a particular instance of vertical integration on a case-by-case basis, it seems unlikely that these theories would support the type of simple policy inference needed to justify holding a specific practice illegal without any particularized inquiry into the facts. Part IV offers an analysis of the intellectual and institutional obstacles for adopting a more comprehensive economic perspective.

It should be noted that the Article's focus on the policy question leads to two caveats. First, in focusing on the economic desirability of permitting vertical integration, I set aside, for the time being, any extended analysis of the important question of whether regulation of vertical integration is either permitted or even compelled under the current regulatory regime. I thus take no position on whether open access is permitted or mandated under current law. ${ }^{25}$ Second, this Article does not address questions of constitutionality. This is not because statutory authorization is unimportant or because regulation of vertical integration does not raise any First Amendment concerns. ${ }^{26}$ It is because both of those

25 For detailed assessments of the statutory status of open access, see generally Chen, supra note 13; Howard A. Shelanski, The Speed Gap: Broadband Infrastructure and Electronic Commerce, 14 BERKELEY TECH. L.J. 721, 740-42 (1999); and Speta, Handicapping, supra note 21, at 61-75.

26 I thus disagree with Lemley and Lessig's suggestion that open access does not implicate the First Amendment. See Lemley \& Lessig, supra note 16, at 955 ("There is no governmental regulation of speech at issue here."). For discussions of the First Amendment implications of open access, see Stuart Minor Benjamin, Proactive Legislation and the First Amendment, 99 MICH. L. REV. 281 (2000); Harold Feld, Whose Line Is It Anyway? The First Amendment and Cable Open Access, 8 COMMLAw CONSPECTUS 23 (2000); and Raymond Shih Ray Ku, Open Internet Access and Freedom of Speech: A First Amendment Catch-22, 75 TUL. L. REV. 87 (2000). 
inquiries focus on what policy makers can do under the law. In so doing, they tend to elide over the more fundamental questions about what policy makers should do. In the absence of an affirmative policy justification for imposing vertical structural regulation, the First Amendment question never arises.

I. The Chain Broadcasting Rules and the Basic Economics of Vertical Integration

This Part will use the FCC's first major initiative designed to regulate vertical relationship in media industries to lay out the basic economic analysis of vertical integration. Section $\mathrm{A}$ begins by outlining the structure of the broadcast television industry and then describes the relevant regulatory scheme, known as the Chain Broadcasting Rules. It then identifies the primary economic arguments upon which the Chain Broadcasting Rules are based, determining that the FCC was motivated by the same concerns that underlay the major judicial decisions on vertical integration: the problems of leveraging and foreclosure.

Section B then reviews the historical development of vertical integration theory, tracing both the Chicago School's critique of the courts' hostility towards vertical integration during the 1950 s and 1960 s, as well as the post-Chicago reaction to that critique. Although these two approaches differ on many of the particulars of competition policy, a close reading of the literature reveals the existence of some common ground. Both approaches recognize the existence of certain structural preconditions that must be satisfied before vertical integration poses any threat to competition. In addition, both approaches acknowledge, for the most part, that vertical integration can yield certain efficiencies that may make vertical integration economically desirable.

The resulting analytical framework is applied to the broadcast television industry in Section C. This analysis reveals that the relevant markets are simply too unconcentrated and too unprotected by barriers to entry for vertical integration to represent a plausible threat to competition. In addition, a review of the cost structure of producing television programming suggests that it is quite possible that vertical integration in the broadcast television industry will yield significant efficiency benefits. Specifically, the existence of significant up-front, fixed-cost investments and minimal marginal costs of transmission make producers of television programming extremely dependent on their ability to reach guaranteed audiences and leave them vulnerable to post-investment opportunistic behavior. Under these circumstances, the limits on vertical integration imposed by the Chain Broadcasting Rules appear to make little sense. 


\section{A. The Chain Broadcasting Rules: Context, Substance, and Rationale}

\section{The Structure of the Broadcasting Industry}

Although the structure of the broadcasting industry may at times seem mysterious, when viewed from a certain perspective, it is in fact quite ordinary. Its basic organization differs little from that of the typical manufacturing industry, which is divided into a three-stage chain of production and distribution comprised of manufacturers, wholesalers, and retailers. The first and last stages are easiest to understand. The first stage is manufacturing, which is occupied by the companies that create the actual products to be sold. Retailers, who are responsible for final delivery of the products to end-users, occupy the last stage. Although it is theoretically possible for retailers to obtain products directly from manufacturers, in practice, the logistics of doing so have become so complicated that it is often necessary for an intermediate stage to develop between manufacturers and retailers. Firms operating at this intermediate stage, known as wholesalers, purchase goods directly from manufacturers and assemble them into complete product lines for retailers to purchase.

The broadcasting industry can, for the most part, be mapped onto this three-stage framework. ${ }^{27}$ For most of the history of the television industry, the manufacturing stage has been populated principally by the movie studios, which create the television programs in the first instance. The wholesale stage is occupied by the networks, which purchase the broadcast rights to programs from the studios, aggregate them into program packages, and redistribute them via satellite to local broadcast stations. The networks in turn sell ${ }^{28}$ these program packages to the local broadcast

27 Although, for the purposes of program distribution, it is proper to regard networks and local broadcast stations as successive stages in a vertical chain of production, that relationship is complicated by the fact that, with regard to advertising, networks and local broadcast stations can be viewed as horizontal competitors. Advertisers have the choice of either spending their advertising money in the national market governed by the networks or in the spot market governed by the local broadcast stations. Although this dimension of competition is also important, this Article will limit its focus to the more vertical aspects of broadcast regulation relating to program distribution.

28 In one sense, it may seem strange to say that networks "sell" program packages to the local broadcast stations. In the typical purchase transaction, one party offers a cash payment in exchange for goods or services provided by another party. In such cases, the cash and the goods travel in opposite directions. In the typical transaction between a network and its broadcast affiliate, the network provides both the program packages and additional money to the station. In other words, the cash and the goods are traveling in the same direction, with the network seemingly receiving nothing in return. The solution to this apparent anomaly is well explained by the Report of the FCC's Network Inquiry Special Staff:

The relationships between the commercial broadcast television networks and their affiliated stations can be characterized in two equivalent ways. The broadcast networks can be described as buying access to the time of stations, paying the stations both in cash and by making time available within and between programs for sale by stations directly 
stations that comprise the retail stage of production responsible for delivering the program packages to the end users. ${ }^{29}$

As with other consumer goods markets, however, regulators became concerned that integration between the different levels of the chain of production might pose a threat to competition. In order to address these concerns, the FCC enacted rules designed to limit the extent to which such vertical integration could occur as one of its first major regulatory initiatives.

\section{The Chain Broadcasting Rules}

Concerned by the increasing dominance that the three major radio networks-NBC, CBS, and the Mutual Broadcasting System-were exerting over their broadcast affiliates, the FCC launched an investigation in 1938 to determine what, if any, restrictions should be placed upon them. ${ }^{30}$ This investigation culminated three years later with the issuance of the Report on Chain Broadcasting ${ }^{31}$ and the enactment of the Chain Broadcasting Rules. ${ }^{32}$

The Chain Broadcasting Rules placed direct restrictions on the extent to which networks could vertically integrate into local broadcasting. ${ }^{33}$ The

to advertisers. Alternatively, one can think of stations as purchasing programs from the networks, paying for these programs by permitting the networks to sell advertising time within programs and to retain a portion of the revenue that is thereby obtained. Under either view, the relationship between networks and their outlets is principally vertical with regard to program exhibition.

1 FCC. NETWORK INQUIRY SPECIAL STAFF, NEW TElEVISION NETWORKS: ENTRY, JURISDICTION, OWNERSHIP, AND REGULATION 395 (1980) [hereinafter NEW TELEVISION NETWORKS] (footnote omitted).

29 It should be noted that not all broadcast programming passes through all three stages of production. For example, broadcast networks on occasion bypass the manufacturing stage by creating their own content, such as news and sports programs. Similarly, local broadcast stations at times bypass both upstream stages by creating local news broadcasts and other original programming. In addition, some programs in effect bypass the network stage and move directly from the movie studios to the local broadcast stations through syndication. Notwithstanding these variations, the basic threestage model is useful to capture the basic structure of the broadcast industry. Indeed, the variations discussed above are largely consistent with the focus of this Article, since the fact that two stages are often collapsed into one can be seen as a form of vertical integration.

30 See 3 Fed. Reg. 637 (Mar. 26, 1938).

31 FEDERAL COMMUNICATIONS COMMISSION, REPORT ON CHAIN BROADCASTING (1941).

32 For useful overviews of the Chain Broadcasting Rules, see Emord, supra note 20, at 40511; NEW TELEVISION NETWORKS, supra note 28 , at 445-49; STANLEY M. BESEN ET AL., Misregulating Television 32-35 (1984) [hereinafter MisRegulating Television]; and Chen, supra note 21 , at 1451-54.

33 Specifically, the FCC prohibited networks from owning more than one station in any market and from owning stations in markets with so few stations that competition would be substantially restrained. REPORT ON CHAIN BROADCASTING, supra note 31, at 92 (Rule 3.106), repealed by Review of the Comm'n's Regulations Governing Television Broad., 10 F.C.C.R. 4538, 4540, 10 (1995) (Report and Order). The former provision has been largely overshadowed by the FCC's duopoly rule, which prohibits all owners, networks and non-networks alike, from owning more than one station in any market. See 47 C.F.R. $\$ 73.355$ (1999). 
FCC later bolstered this limit to vertical integration by promulgating rules limiting the number of television stations that any one person could own. ${ }^{34}$ Although the initial rule banned any person from owning more than three stations, ${ }^{35}$ this number increased steadily over the years. ${ }^{36}$ Current law permits ownership of any number of stations so long as the total reach of the group does not exceed thirty-five percent of the national audience. ${ }^{37}$ Although not targeted towards the networks specifically, the national ownership rules serve as the primary limit on network ownership of broadcast stations. ${ }^{38}$

The Chain Broadcasting Rules also included a number of restrictions on the networks' ability to use vertical contractual restraints, banning the use of contract provisions requiring exclusive dealing, territorial exclusivity, and long affiliation terms. ${ }^{39}$ In addition, the rules guaranteed the local stations' right to reject any programs that they deemed unsatisfactory ${ }^{40}$ and restricted the use of contract provisions granting networks guaranteed access to affiliates' time during certain portions of the broadcast day (a practice known as "option time"). ${ }^{41}$

In the landmark case of $N B C v$. United States, ${ }^{42}$ the Supreme Court upheld the Chain Broadcasting Rules as a proper exercise of the FCC's statutory obligation to regulate broadcasting in accordance with the public

34 For reviews of the history of the group ownership rules, see Chen, supra note 21 , at 1445-46; and Glen O. Robinson, The "New" Communications Act: A Second Opinion, 29 CONN. L. REV. 289, 292 (1996).

35 See Rules and Regulations Governing Experimental Television Broad. Stations § 4.226, 6 Fed. Reg. 2282, 2284-85 (May 6, 1941).

36 See Multiple Ownership, 9 Fed. Reg. 5442 (May 23, 1944) (authorizing group ownership of up to five radio stations); Amendment of Sections 3.35, 3.240 and 3.636 of the Rules and Regulations Relating to the Multiple Ownership of AM, FM, and Television Broad. Stations, 18 F.C.C. 288 (1953) (Report and Order) (limiting any one owner to five television stations nationwide); Amendment of Multiple Ownership Rules, 43 F.C.C. 2797 (1954) (Report and Order) (authorizing group ownership of up to seven stations so long as two stations were UHF); Amendment of Section 73.3555 [formerly Sections 73.35, 73.240 and 73.636] of the Comm'n's Rules Relating to Multiple Ownership of AM, FM and Television Broad. Stations Amendment of Multiple Ownership Rules, 100 F.C.C.2d 17 (1984) (Memorandum Opinion and Order) (authorizing group ownership of up to twelve stations), on reconsideration, 100 F.C.C.2d 74 (1985) (Memorandum Opinion and Order) (adding the additional requirement that the group reach no more than twenty-five percent of the national audience).

37 Telecommunications Act of 1996, Pub. L. No. 104-104, § 202(c), 110 Stat. 56, 110 (codified as 47 C.F.R. $\$ 73.3555(\mathrm{e})(1)$ (1999)). Interestingly, the FCC had already signaled its willingness to consider raising the cap to as high as fifty percent by the time the Act was passed. See Robinson, supra note 34, at 292 (citing Broad. Servs.; Television Stations, 60 Fed. Reg. 6490 (1995)).

38 See 100 F.C.C.2d at 50-54, १ 97-107.

3947 C.F.R. $\$ 73.658(\mathrm{a})-(\mathrm{c})(1999)$.

$40 \quad$ Id. $\S 73.658(\mathrm{e})$.

41 The FCC rejected the Chain Broadcasting Report's call for an outright ban of option time, opting instead to place additional restrictions on it. 6 Fed. Reg. 5258 (1941) (extending the minimum notice period for the exercise of option time to fifty-six days and limiting the number of hours that could be reserved through option time). The FCC banned option time altogether in 1963. Option Time and the Station's Right to Reject Network Programs, 34 F.C.C. 1103, 1130 (1963) (Second Report and Order) (codified at 47 C.F.R. $\$ 73.658(d)(1999)$ ).

42319 U.S. 190 (1943). 
interest. ${ }^{43}$ Consistent with the spirit of the day ${ }^{44}$ the Court did not subject the economic rationales underlying the Rules to any significant scrutiny, opting instead to defer to the agency in this regard. ${ }^{45}$ The Court later relied heavily on this decision in subsequently upholding the national ownership rules. ${ }^{46}$

In 1946, the FCC extended the Chain Broadcasting Rules to television without conducting any specific analysis of their applicability to the new medium. ${ }^{47}$ This action was clearly prophylactic, as there were only six television stations on the air in the entire U.S. at the time. ${ }^{48}$ The FCC has since largely eliminated the Chain Broadcasting Rules with respect to radio, ${ }^{49}$ so, as a practical matter, their only remaining relevance is with respect to television.

\section{The Economic Theory Underlying the Chain Broadcasting Rules}

The Chain Broadcasting Rules reflected the FCC's belief that the networks were using vertical integration and vertical contractual restraints to harm competition in two ways. First, the FCC was concerned that the use of such provisions allowed networks to use their dominant positions to reduce the local broadcast stations' freedom to choose, ${ }^{50}$ a concern analogous to the concern in antitrust theory that a dominant firm might "leverage" its market power over one stage of production to reduce competition in an adjacent stage that otherwise would be competitive. Second, the FCC was also concerned that allowing networks to tie up local broadcast stations tended to obstruct the growth of new networks, ${ }^{51}$ a concern analogous to modern concerns about "foreclosure."

43 Id. at 215-19.

44 See, e.g., James LANDIS, The Administrative Process 95-103, 132-40 (1938). For general descriptions of the courts' deferential attitude towards agency policymaking, see Thomas W. Merrill, Capture Theory and the Courts: 1967-1983, 72 CHI.-KENT L. REV. 1039, 1048-50, 1056-59 (1997); Reuel E. Schiller, Enlarging the Administrative Polity: Administrative Law and the Changing Definition of Pluralism, 1945-1970, 53 VAND. L. REV. 1389, 1417-19 (2000); Richard B. Stewart, The Reformation of American Administrative Law, 88 HARV. L. REV. 1669, 1677-78 (1975); and Keith Werhan, The Neoclassical Revival in Administrative Law, 44 ADMIN. L. REV. 567, 574-75 (1992).

45319 U.S. at 218-19; see also id. at 224-25 (rejecting the argument that the Chain Broadcasting Rules were arbitrary and capricious).

46 United States v. Storer Broad. Co., 351 U.S. 192 (1956).

47 Amendment to Part 3 of the Comm'n's Rules, 11 Fed. Reg. 33 (1946).

48 See Review of the Comm'n's Regulations Governing Television Broad, 10 F.C.C.R. 4538,4539, \ 5 (1995) (Report and Order).

49 Review of Comm'n Rules and Regulatory Policies Conceming Network Broad. by Standard (AM) and FM Broad. Stations, 63 F.C.C.2d 674 (1977) (Report, Statement of Policy, and Order).

50 See REPORT ON CHAIN BROADCASTING, supra note 31 , at 4, 52, 65- 67.

51 See id. at $51-52,54,59,62,67$. It should be noted that the FCC also based its report in part on considerations unrelated to competition policy. For example, at times, the Report on Chain Broadcasting also relies in part on concerns more closely allied with the First Amendment, such as the perceived need to encourage locally produced programming. See id. at 4,63, 65 . 
The Chain Broadcasting Rules' reliance on the perceived dangers posed by leveraging and foreclosure was an apt reflection of the prevailing economic wisdom of the day. At the time, the Harvard School of Industrial Organization $^{52}$ ("Harvard School"), associated with the work of economist Joe Bain ${ }^{53}$ and legal scholars Carl Kaysen and Donald Turner, ${ }^{54}$ dominated antitrust law. The Harvard School based its hostility towards vertical integration on three central tenets. First, it readily accepted the leverage theory of vertical integration, believing that firms with as little as five percent of the market could use vertical integration to exert market power against upstream and downstream markets. ${ }^{55}$ Second, the Harvard School also believed that vertical integration allowed firms to foreclose entry either by tying up the supply of necessary inputs ${ }^{56}$ or by forcing new entrants to enter at two different levels of production. ${ }^{57}$ Third, Harvard School scholars believed that vertical integration provided few efficiency benefits ${ }^{58}$ and was more often motivated by the desire to create barriers to entry. ${ }^{59}$

From the 1950s through the early 1970s, the Harvard School swept the field ${ }^{60}$ and became the orthodox position on the Supreme Court. ${ }^{61}$ In

52 For helpful overviews of the Harvard School approach, see HERBERT HOVENKAMP, FEDERAL ANTITRUST POLICY $§ 1.7$, at 42-46, $\S 2.2 \mathrm{a}$, at 60 (2d ed. 1999); F. M. SCHERER, INDUSTRIAL MARKet StRUCTURE AND ECONOMIC PERFormaNCE 4-6 (1970); Peter C. Carstensen, Antitrust Law and the Paradigm of Industrial Organization, 16 U.C. DAVIS L. REV. 487, 493-501 (1983); Robert J. Larner \& James W. Meehan, Jr., The Structural School, Its Critics, and Its Progeny: An Assessment, in ECONOMICS AND ANTITRUST POLICY 179, 180-91 (Robert J. Lamer \& James W. Meehan, Jr. eds., 1989); Leonard W. Weiss, The Structure-Conduct-Performance Paradigm and Antitrust, 127 U. PA. L. REV. 1104, 1104-23 (1979); and Oliver E. Williamson, Antitrust Enforcement: Where It's Been, Where It's Going, 27 ST. LOUIS U. L.J. 289, 290-92, 312-13 (1983).

53 JOE S. BAIN, BARRIERS TO NEW COMPETITION 155-56 (1956); JOE S. BAIN, INDUSTRIAL ORGANIZATION 179, 360-64, 381 (2d ed. 1968).

54 CARL KAYSEN \& DONALD F. TURNER, ANTITRUST POLICY: AN ECONOMIC AND LEGAL ANALYSIS (1959); CARL KAYSEN, UNITED STATES V. UNITED SHOE MACHINERY CORPORATION: AN ECONOMIC ANALYSIS OF AN ANTI-TRUST CASE (1956); Donald Tumer, The Validity of Tying Arrangements Under the Antitrust Laws, 72 HARV. L. REV. 50 (1958). In fact, Kaysen was able to influence doctrine directly when he served as a law clerk to Judge Wyzanski in one of the leading antitrust cases of its time. See Carl Kaysen, In Memoriam: Charles E. Wyzanski, Jr., 100 HARV. L. REV. 713, 713-15 (1987).

55 See KAYSEN \& TURNER, supra note 54, at 132 (arguing that firms "can, through the leverage effects of firms in one market on those in another to which they stand in the relation of supplier or customer, enhance existing power, or enable it to be applied in a new market").

56 See id. at 121 ("Vertical integration backward over limited raw material supplies or forward over limited market outlets may provide either the basic sources of the market power of the firm or important buttresses to it.").

57 See id. at 120.

58 See BAIN, Barriers to New COMPETITION, supra note 53, at 155-56; BAIN, INDUSTRIAL ORGANIZATION, supra note 53, at 179, 360-64, 381 .

59 See BAIN, BARRIERS TO NEW COMPETITION, supra note 53, at 144-47.

60 In fact, at the time, the Harvard School counted even such future critics as George Stigler, Ward Bowman, and Milton Friedman among its adherents. See GEORGE STIGLER, MEMOIRS OF AN UNREGULATED ECONOMIST 97, 99-100 (1988); Ward S. Bowman, Jr., Toward Less Monopoly, 101 U. PA. L. REV. 577, 589, 641 (1953). 
case after case, the Court struck down vertical mergers by firms controlling as little as five percent of the market. ${ }^{62}$ The Court followed a parallel pattern with respect to vertical contractual restraints, either holding them illegal per se on the grounds that the restraint at issue evinced such a "pernicious effect on competition" and such a "lack of any redeeming virtue" that little would be lost if they were "presumed to be ... illegal without elaborate inquiry as to the precise harm they have caused or the business excuse for their use" ${ }^{, 63}$ or striking them down at such low levels of concentration as to be tantamount to the same thing. ${ }^{64}$ The Harvard School approach also became enshrined in the initial Merger Guidelines issued by the Justice Department in 1968, which disfavored any vertical merger involving a firm holding as little as six to ten percent of its market. ${ }^{65}$ Given the prevailing hostility towards vertical integration, it seemed quite natural for the FCC to impose categorical regulations that in essence made vertical integration in the broadcast industry illegal per se.

\section{B. The Basic Economics of Vertical Integration ${ }^{66}$}

\section{The Chicago School's Rejection of Per Se Illegality}

The academic and doctrinal consensus in place at the time the FCC established the Chain Broadcasting Rules would not prove to be lasting. A new body of economic scholarship, spearheaded by a group of economists associated with the University of Chicago, ${ }^{67}$ unleashed a critique of the Harvard School's approach to vertical integration that remains one of the central influences in competition policy to this day.

61 See Louis Kaplow, Extension of Monopoly Power Through Leverage, 85 CoLUM. L. REV. 515, 516-17 (1985).

62 See Ford Motor Co. v. United States, 405 U.S. 562, 578 (1971) (striking down vertical merger resulting in 10\% foreclosure); Brown Shoe Co. v. United States, 370 U.S. 294, 328-34 (1961) (striking down vertical merger resulting in $5 \%$ and $1 \%$ foreclosure); United States v. E.I. du Pont de Nemours \& Co., 353 U.S. 586 (1956) (striking down vertical merger resulting in $6 \%$ to $7 \%$ foreclosure)

63 N. Pac. Ry. Co. v. United States, 356 U.S. 1, 5 (1957) (holding tying illegal per se); see also United States v. Loew's, Inc., 371 U.S. 38, 45 (1962) (same); Fortner Enters., Inc. v. United States Steel Corp., 394 U.S. 495, $498-99$ (1968) (same); United States v. Amold, Schwinn \& Co., 388 U.S. 365 (1966) (holding territorial restrictions illegal per se); White Motor Co. v. United States, 372 U.S. 253 (1962) (same).

64 See, e.g., Standard Oil Co. v. United States, 337 U.S. 293, 314 (1948) (striking down exclusive dealing contract that foreclosed $16 \%$ of the market)

65 U.S. Department of Justice Merger Guidelines $\S 12,33$ Fed. Reg. 23,442 (1968), reprinted in 4 Trade Reg. Rep. (CCH) \$13,101

66 Readers already familiar with the basic economics of vertical integration might prefer to skip directly to infra Section I.C.

67 For a useful overview of the Chicago School, see Richard A. Posner, The Chicago School of Antitrust Analysis, 127 U. PA. L. REV. 925 (1979). 
The Chicago School systematically called into question each of the three central propositions that underlay the Harvard School's hostility towards vertical integration. First, the Chicago School argued that the leverage theory of vertical integration provided neither the incentive nor the ability to harm competition. Second, the Chicago School attacked the notion that vertical integration could foreclose entry. Third, Chicagoans offered plausible arguments that vertical integration could lead to more significant efficiency benefits than the Harvard School thought possible. I will discuss each in turn.

\section{a. The Critique of Leverage}

The Chicago School leveled a twofold attack on the notion that firms could use vertical integration to gain leverage over another market. One attack focused on the structural preconditions required to state a coherent leveraging claim. The other attack was more radical; it argued that, even when the structural preconditions identified in the first attack were met, vertical integration did not provide firms with any additional market power. As a result, the Chicagoans argued, firms will generally find leverage to be unnecessary.

Beginning with the first attack, Chicagoans pointed out that it is impossible to state a coherent theory of leverage unless two structural preconditions are met. First, the merging firm must have monopoly power in its primary market since, without such power, any attempt to charge supra-competitive prices would simply induce customers to obtain the goods they need from other sources. In short, a firm that lacks market power has nothing to leverage in the first place. ${ }^{68}$ Second, the market into which the firm seeks to vertically integrate (called the secondary market) must also be concentrated and protected by barriers to entry. If no such barriers to entry exist, any attempt to raise price in the secondary market will simply attract new competitors until the price drops back down to competitive levels. ${ }^{69}$ Unless these two structural preconditions are met, it is impossible to see how vertical integration could provide any firm with the ability to extract any profit from either market.

In addition, the Chicago School pointed out that, although firms with monopoly power may have the ability to exercise leverage over upstream and downstream markets, those firms typically lack the incentive to do so.

68 See Richard A. PoSner \& Frank H. EAsterbrook, ANTITRust 870-71 (2d ed. 1982) ("The leverage theory . . . is beside the point if the integrated firm lacks a monopoly."); Aaron Director \& Edward H. Levi, Law and the Future: Trade Regulation, 51 Nw. U. L. REv. 281, 290 (1956) ("Firms that are competitive cannot impose coercive restrictions on their suppliers or their customers as a means of obtaining a monopoly. They lack the power to do this effectively.").

69 See RiChard A. POSNER, ANTITRust LAW: AN ECONOMiC PERSPECTIVE 172-73 (1976). 
This is because there is only one monopoly profit in any chain of production, and any monopolist can capture all of that profit without having to resort to vertical integration. All it has to do is simply price its goods at the monopoly level. ${ }^{70}$

A simple numerical example will help illustrate the point. ${ }^{71}$ Suppose that a monopolist refines ore into copper ingot and sells it to a downstream firm that fabricates the ingot into copper pipe that is sold into a competitive market. Suppose further that the cost of refining ore into ingot is $\$ 40$, that the cost of fabricating the ingot into pipe is $\$ 35$, and that the monopoly price of the final good is $\$ 100$. If the monopolist were to vertically integrate into fabrication, it could charge $\$ 100$ for the final good and thereby earn a profit of $\$ 25$ per unit (i.e., $\$ 100-\$ 40-\$ 35$ ). The monopolist need not vertically integrate to capture this profit, however. All it needs to do is price the ingot at $\$ 65$, which would allow it to earn the same profit of $\$ 25$ per unit (i.e., $\$ 65-\$ 40$ ). Since the downstream firm faces competition, it will simply set its markup equal to its costs. This results in the price of the final good also being set at its profit-maximizing price of $\$ 100$ (i.e., $\$ 65+\$ 35$ ). Thus, as a general matter, the monopolist gains nothing by vertically integrating into fabrication. All it needs to do to capture all of the available profit is simply price the input so that the final good is priced at the monopoly level.

Chicago School scholars did note two relevant exceptions to their critique of leveraging. First, they pointed out that leverage might be profitable if the monopolist controls an input that can be used in variable proportions with other competitively supplied inputs. ${ }^{72}$ The logic is straightforward: A firm with monopoly control over an input will price it

70 See ROBERT H. BORK, THE ANTITRUST PARADOX 226-31, 372-73, 375 (1978); POSNER, supra note 69, at 173, 197; POSNER \& EASTERBROOK, supra note 68, at 802-03, 870; Ward S. Bowman, Jr., Tying Arrangements and the Leverage Problem, 67 YALE L.J. 19, 20-21 (1957); Director \& Levi, supra note 68 , at 290.

71 The example is taken from Town of Concord v. Boston Edison Co., 915 F.2d 17, 32 (1st Cir. 1990) (Breyer, C.J.), cert. denied, 499 U.S. 931 (1991).

72 See BORK, supra note 70, at 229-31; POSNER, supra note 69, at 201; POSNER \& EASTERBROOK, supra note 68, at 874; Bowman, supra note 70, at 25-27; M.L Burstein, $A$ Theory of Full-Line Forcing, 55 Nw. U. L. REv. 62, 68, 76-83 (1960); John S. McGee \& Lowell R. Bassett, Vertical Integration Revisited, 19 J.L. \& ECON. 17, 22-32, 38 (1976); Posner, supra note 67, at 937. For the seminal economic articles, see L.W. McKenzie, Ideal Output and the Interdependence of Firms, 61 ECON. J. 785 (1951); and John M. Vernon \& Daniel A. Graham, Profitability of Monopolization by Vertical Integration, 79 J. POL. ECON. 924 (1971). For useful reviews appearing in the economic literature, see BLAIR \& KASERMAN, supra note 24, at 31-35; F.M. SCHERER \& DAVID Ross, Industrial MARKet STRUCTURE AND ECONOMIC PERFORMANCE 522-27 (3d ed. 1990); TIROLE, supra note 24, at 179-81; Masahiro Abiru, Vertical Integration, Variable Proportions, and Successive Oligopolies, 36 J. INDUS. ECON. 315, 324 (1988); and Martin K. Perry, Vertical Integration: Determinants and Effects, in 1 HANDBOOK OF INDUSTRIAL ORGANIZATION 183, 191-92 (Richard Schmalensee \& Robert D. Willig eds., 1989). For overviews appearing in the legal literature, see HOVENKAMP, supra note 52, § 9.3a, at 377-78; Chen \& Hylton, supra note 24, at 598-99, 627-28; and David Reiffen \& Michael Vita, Is There New Thinking on Vertical Mergers?, 63 ANTITRUST L.J. 917, 922-24 (1995). 
above cost. This price increase will lead customers to substitute alternative inputs whenever possible, a reaction that reduces the monopolist's market power and decreases the profits it earns. The input can eliminate the reduction in profits resulting from input substitution by vertically integrating into fabrication. ${ }^{73}$

Chicago School scholars conceded that, under these circumstances, a monopolist could use vertical integration to earn positive profits, but tended to downplay the significance of the insight. ${ }^{74}$ Subsequent economists have largely agreed, in part because the welfare implications of input substitution are actually quite ambiguous. ${ }^{75}$ Although input substitution can reduce monopoly profits, it also reduces total welfare by inducing customers to deviate from the most efficient input mix. Determining which of the two countervailing effects will dominate can be quite difficult. ${ }^{76}$ In any event, any reduction in welfare is likely to be relatively small. ${ }^{77}$ As a result, the consensus position is that input substitution does not pose a problem significant enough to be worth redressing. ${ }^{78}$ And even in markets where market power exists, it is

73 The monopolist could accomplish much the same effect through vertical contractual restraints requiring that customers agree not to substitute inputs.

74 See BORK, supra note 70, at 229-31 (arguing that input substitution rarely occurrs and as a result was an insufficient basis for regarding vertical mergers as anything but per se legal); POSNER, supra note 69, at 201 (arguing that "[w]hich effect dominates is an empirical question in each case, and probably an unanswerable one in the present state of economic science. There is accordingly no basis, as yet at least, for prohibiting these vertical mergers either") (footnote omitted); McGee \& Bassett, supra note 72 , at 32,38 (accepting the insight, but arguing that it should be addressed through horizontal remedies).

75 See George A. Hay, An Economic Analysis of Vertical Integration, 1 IND. ORG. REV. 188 (1973); Richard Schmalensee, $A$ Note on the Theory of Vertical Integration, 81 J. POL. ECON. 442, 448 (1973); Frederick R. Warren-Boulton, Vertical Control with Variable Proportions, 82 J. POL. ECON. $783,794-96,798,799$ (1974).

76 SCHERER \& ROSS, supra note 72, at 523-24 ("The mathematical conditions underiying this resuit are complex."). Specifically, the welfare tradeoff described above turned largely on the elasticity of substitution and the elasticity of demand for the final good. Economists that have assumed that the final product market is perfectly competitive have disagreed over the range of elasticities that lead to a price increase. Compare Hay, supra note 75, at 194; Warren-Boulton, supra note 75, at 784, 787, 799; and Schmalensee, supra note 75, at 447, with Parthasaradhi Mallela \& Babu Nahata, Theory of Vertical Control with Variable Proportions, 88 J. POL. ECON. 1007, 1014-15 (1980); and Fred M. Westfield, Vertical Integration: Does Product Price Rise or Fall?, 71 AM. ECON. REV. 334, 335-346 (1981). Scholars that have modeled the final product market as oligopolistic have reached similar disagreement. Compare Michael Waterson, Vertical Integration, Variable Proportions and Oligopoly, 92 ECON. J. 129, 139 (1982) (concluding that, if the final product market is oligopolistic rather than competitive, the impact on welfare depends on the elasticity of substitution), with Abiru, supra note 72 , at 324 (employing similar assumptions to conclude that price will fall and welfare will increase regardless of elasticity of substitution).

77 Perry, supra note 72, at 192 (noting that the percentage welfare loss appears to be less than a couple percent); Reiffen \& Vita, supra note 72, at 923 (drawing the same conclusion).

78 See Perry, supra note 72 , at 192 ("[I]t is not clear that variable proportions raises a major policy issue on vertical integration."); Reiffen \& Vita, supra note 72, at 923 ("The variable proportions models of vertical integration seldom have been regarded as providing a sound basis for guiding vertical merger enforcement policy."). 
arguable that horizontal remedies will prove more effective in curbing it than any prohibition of vertical integration or vertical restraints. ${ }^{79}$

The second exception is more significant for the purposes of this Article. It acknowledges that a monopolist subject to rate regulation may well find it profitable to integrate vertically. Gaining control of a second, unregulated level of production would allow the firm to earn the profits foreclosed by regulators. ${ }^{80}$ In such cases, it is arguably appropriate to prohibit vertical integration in order to isolate and quarantine the monopolist. Such regulation is justified, however, only in cases of natural monopoly, where any attempt to break up the monopoly would ultimately prove futile. If the market at issue is not a natural monopoly, both rate regulation and the concomitant prohibition of vertical integration are equally unwarranted.

\section{b. The Critique of Foreclosure}

Chicago School supporters also debunked the notion that a firm without market power could use vertical integration to foreclose competitors. Suppose that a shoe manufacturer that controls a nondominant share of total shoe manufacturing (say, ten percent) decides to integrate vertically into retail shoe stores and sell its shoes only through dedicated outlets. ${ }^{81}$ It cannot be said that the decision to integrate vertically has foreclosed any of the shoe manufacturer's existing competitors, since they still have available the number of shoe retailers (ninety percent) sufficient to allow them sell all of their available supply (ninety percent). Vertical integration into retailing may realign the patterns of distribution, but it cannot limit the amount of the market available to rivals. ${ }^{82}$

79 William F. Shughart II, The ORganization of INDUSTRY 324 (1990); McGee \& Bassett, supra note 72, at 22-32, 38; Perry, supra note 72, at 192.

80 BORK, supra note 70, at 376; POSNER \& EASTERBROOK, supra note 68 , at $809,870 \mathrm{n} .2$; Bowman, supra note 70, at 21-23. For a detailed exposition of AT\&T's use of this form of leverage to harm competition for long distance telephony, see Timothy J. Brennan, Why Regulated Firms Should Be Kept Out of Unregulated Markets: Understanding the Divestiture in U.S. v. AT\&T, 32 ANTITRUST BULL. 741 (1987).

81 Those familiar with antitrust will recognize that this hypothetical is based on the facts of Brown Shoe Co. v. United States, 370 U.S. 294 (1962).

82 BORK, supra note 70, at 232; Sam Peltzman, Issues in Vertical Integration Policy, in Public Policy Towards Mergers 167, 169-70 (J. Fred Weston \& Sam Peltzman eds., 1969). Posner and Easterbrook illustrate the point with the following numerical example:

Suppose GM bought $10 \%$ of its gasket needs from each of 10 firms ( $A$ through $J$ ), that GM purchased $10 \%$ of all gaskets sold in America, and that firms $A$ through $J$ were of equal size. GM now purchases firm $A$ and announces that it will buy its gasket requirements from $A$ exclusively. Would $B$ through $J$ care? No. They still would have $90 \%$ of the nation's gasket production capacity and would supply $90 \%$ of the market. The firms to which $A$ used to ship $90 \%$ of its gasket output now would tum to the market and find $B$ through $J$ ready to supply that demand. The number of gaskets sold is unchanged; market shares are unchanged; only the patterns of sales are altered.

POSNER \& EASTERBROOK, supra note 68 , at 870. 
In addition, the Chicago School argued that vertical integration between shoe manufacturers and shoe retailers cannot deter new entry unless there are barriers to entry protecting the shoe retailing market. This is because, even if the existing shoe manufacturers have locked up all of the existing shoe retailers, absent barriers to entry in retailing, any new shoe manufacturer seeking to find distribution should find distributors waiting to meet it. ${ }^{83}$

\section{c. Efficiency Justifications for Vertical Integration}

Having cast doubt on whether vertical integration could plausibly harm competition in the absence of monopoly power in the first market and barriers to entry protecting the second market, Chicago School scholars bolstered their campaign against the per se illegality of vertical integration by identifying several ways in which vertical integration could actually enhance efficiency. The two sources of efficiency most relevant to the purposes of this Article are the elimination of double marginalization resulting from successive monopolies and the reduction of transaction costs.

Elimination of Double Marginalization. Drawing on the pioneering work of Joseph Spengler, ${ }^{84}$ Chicagoans pointed out that vertical integration or restraints can be welfare-enhancing when successive stages of production are both controlled by monopolies. ${ }^{85}$ Chicago School scholars pointed out that this so-called "double marginalization" problem leads successive monopolies to set higher prices than would firms that used some vertical device to coordinate pricing decisions. It has now become generally accepted that vertical integration between successive monopolists is unambiguously welfare-enhancing. ${ }^{86}$

83 See BORK, supra note 70, at 241; POSNER, supra note 69, at 197-98; GEORGE J. STIGLER, THE ORGANIZATION OF INDUSTRY 113-22 (1968); Director \& Levi, supra note 68, at 293.

84 See Joseph J. Spengler, Vertical Integration and Antitrust Policy, 58 J. POL. ECON. 347 (1950); see also Fritz Machlup \& Martha Taber, Bilateral Monopoly, Successive Monopoly, and Vertical Integration, 27 ECONOMICA 101 (1960) (reviewing the early scholarship on successive monopoly theory).

85 See BORK, supra note 70, at 229; POSNER, supra note 69, at 200-01; POSNER \& EASTERBROOK, supra note 68 , at $875-76$; Peltzman, supra note 82 , at $171 \mathrm{n} .3$; see also Fishman v. Estate of Wirtz, 807 F.2d 520, 563 (7th Cir. 1986) (Easterbrook, J., dissenting). For useful discussions of the economic literature on successive monopoly, see BLAIR \& KASERMAN, supra note 24, at 31-36; TIROLE, supra note 24, at 174-77; and FREDERICK R. WARREN-BOULTON, VERTICAL CONTROL OF MARKETS 51-63, 80-82 n.1 (1978). For useful discussions appearing in the legal literature, see HOVENKAMP, supra note 52, $\$ 9.2 c$, at 374-77; and Chen \& Hylton, supra note 24, at 595-97, 631-32.

86 TIROLE, supra note 24, at 177 ("[W]elfare is unambiguously increased by the elimination of the double marginalization."); Roger D. Blair \& Jeffrey L. Harrison, Antitrust Policy and Monopsony, 76 CORNELL L. REV. 297, 328 (1991) ("The welfare effects of the monopsonist's backward vertical integration are unambiguously positive."); Chen \& Hylton, supra note 24, at 598 ("In sum, vertical integration makes both the producers and consumers better off."); see also Wirtz, 807 F.2d at 563 (Easterbrook, J., dissenting) ("Propositions about the economics of mergers often are 
Again, the example involving the fabrication of copper ingot into copper pipe discussed above provides a useful illustration. ${ }^{87}$ Suppose that both the company that refined copper ore into ingot and the company that fabricated the ingot into pipe were both monopolists. As noted before, the cost of manufacturing the ingot was assumed to be $\$ 40$, the cost of fabricating the ingot into pipe was $\$ 35$, and the profit-maximizing price for pipe was $\$ 100$. In an effort to capture all of the monopoly profit, the ingot monopolist would charge $\$ 65$ for the ingot $\$ 40$ in costs $+\$ 25$ in available profit) and hope that the pipe fabricator will price at cost. The pipe fabricator will similarly attempt to capture all of the available profit by charging $\$ 60$ ( $\$ 35$ in costs $+\$ 25$ in available profit) and hope that the ingot manufacturer will price at cost. The result is that the final product will cost $\$ 125$, a price driven well above profit-maximizing levels that would be in the self-interest of the two monopolists. Although both firms could increase the total profit available by agreeing on a way to reduce the final price, the fact that the firms are locked into a classic bilateral monopoly will render the terms of any such agreement indeterminate and greatly increase the likelihood of deadlock. ${ }^{88}$ Vertical integration would eliminate this problem, however, since the integrated entity would simply set the final price of the pipe at the profit-maximizing level of $\$ 100$ without having to worry about the allocation of the monopoly profits between the two different stages of production.

Reduction of Transaction Costs. The Chicago School also contended that vertical integration could promote efficiency by reducing transaction costs. Some of these arguments followed the Coasean insight ${ }^{89}$ that integration can reduce the overall friction involved in organizing business enterprises by internalizing certain transactions within the firm. ${ }^{90}$ Others suggested that vertical integration can lead to efficiencies by allowing firms to avoid the transaction costs associated with protecting themselves against opportunistic behavior. In particular, the literature identifies at least three types of opportunistic behavior that firms may seek to avoid.

Hold Up. The landmark article by Benjamin Klein, Robert Crawford, and Armen Alchian identified a type of opportunistic behavior that can arise whenever a firm makes an investment that is uniquely tailored to the needs of the other. When the cost of such an asset exceeds the value of its next-best use, the investment is said to create "appropriable quasi-rents,"

\footnotetext{
filled with ifs and maybes; competing schools of thought produce different prescriptions. That successive monopolies injure consumers is a proposition on which there is unanimous agreement.").

87 See supra note 71 and accompanying text.

88 Machlup \& Taber, supra note 84, at 105-06, 111-13; Wirtz, 807 F.2d at 563 (Easterbrook, J., dissenting).

89 R.H. Coase, The Theory of the Firm, 4 ECONOMICA 386 (1937).

90 See BORK, supra note 70, at 227.
} 
because they allow others to hold up the investing party in an attempt to extract a greater proportion of the joint benefits. ${ }^{91}$

Firms confronting the risk of such opportunistic behavior essentially have two options. First, they can attempt to anticipate the problems and incorporate solutions to them into the contractual relationship. ${ }^{92}$ Negotiating and enforcing such contracts can be quite costly, and the costs of protecting one's interests via contract rise dramatically as the size of the relationship-specific investment increases and as information becomes increasingly asymmetric and hard to verify. These problems are exacerbated still further if the risks associated with the project are high and the number of alternative business partners is relatively small. ${ }^{93}$ In addition, the impossibility of anticipating every possible contingency inevitably means that all contracts are in some way analytically incomplete. At some point, transaction costs may rise to the point where they frustrate the parties' ability to reach a mutually beneficial bargain. When this occurs, the firms may find it beneficial to solve the problem through vertical integration. Bringing the two firms under the same corporate umbrella eliminates the incentives for engaging in opportunistic behavior designed to affect the division of profits between the two firms. The firms can then give their undivided attention to determining the combination of resources that maximizes joint profits and, as a result, maximizes total welfare. ${ }^{94}$

The classic example discussed in the literature is GM's 1926 acquisition of one of its component manufacturers, Fisher Body. ${ }^{95}$ According to Klein, Crawford, and Alchian, the shift from wooden to metal automobile bodies required Fisher Body to make investments in new metal stamping technology unique to GM's cars. Under the KleinCrawford-Alchian framework, the existence of such relationship-specific investments raised the danger that GM would act opportunistically against Fisher Body after the investment costs had already been sunk. To mitigate this risk, GM and Fisher Body entered into a long-term exclusive dealing agreement in which the price was set at operating costs plus a substantial

91 Benjamin Klein, Robert G. Crawford, \& Armen A. Alchian, Vertical Integration, Appropriable Rents, and the Competitive Contracting Process, 21 J.L. \& ECON. 297, 298 (1978).

92 Id. at 302-07; see also POSNER \& EASTERBROOK, supra note 68, at 886 ("[L]ong term exclusive dealing contracts may be an effective way of dealing with opportunistic behavior.").

93 See Williamson, supra note 24 , at 22-24, 28-29; Chen \& Hylton, supra note 24 , at 59091.

94 Oliver E. Willlamson, The ECONomic Institutions of Capitalism 48-49 (1985); Paul L. Joskow, Vertical Integration and Long-Term Contracts: The Case of Coal-Burning Electric Generating Plants, 1 J.L. ECON. \& ORG. 33, 37 (1985); Klein et al., supra note 91, at 302-04; see also Chen \& Hylton, supra note 24, at 591; Perry, supra note 72 , at 214.

95 Klein et al, supra note 91 , at 308-10. For a discussion of the seminal place that the Fisher Body case has taken in the literature, see Daniel F. Spulber, Economic Fables and Public Policy, in FAMOUS FABLES OF ECONOMiCS 15-18 (Daniel F. Spulber ed., 2002). 
markup for capital costs. While well-designed to protect Fisher Body against opportunistic behavior by GM, Klein, Crawford, and Alchian contend that the contract was not well-designed to protect GM against opportunistic behavior by Fisher Body. When the demand for metalbodied automobiles increased dramatically, Fisher Body was able to use its capital investments much more efficiently than the original contract had envisioned, and the existing formula allowed Fisher Body to charge GM prices that overcompensated it for its capital costs. In addition, Klein, Crawford, and Alchian argue that Fisher Body maximized its own profits by employing labor-intensive production methods that were technologically inefficient and by refusing to locate its plants near GM's. Unable to manage its relationship with its input supplier through contractual devices, GM was left with no choice but to vertically integrate backwards into body fabrication by acquiring Fisher Body. ${ }^{96}$

Free Riding. Free riding represents another type of opportunistic behavior that can cause transaction costs to rise. As Lester Telser's seminal article demonstrated, transaction costs tend to rise any time a firm is not able to capture all of the benefits created by its own conduct, because the existence of such positive externalities gives other firms the incentive to attempt to free ride on the benefits created by other firms. ${ }^{97}$ For example, suppose that a firm manufactures a technically complicated product that requires significant presale services (such as the demonstration of the product). Telser argues that retailers will have the incentive to shirk in providing such services in the hopes that other retailers will bear the costs of providing such services. If all retailers respond to these incentives in the same way, the total amount of presale services will fall below efficient levels. ${ }^{98}$

A manufacturer facing the possibility of such free riding has two alternatives. It can contractually specify the level of presale services that each retailer is required to offer. Alternatively, it might attempt to rely on a vertical contractual restraint, such as resale price maintenance or exclusive sales territories, to align the retailers' incentives with the manufacturers'. ${ }^{99}$

\footnotetext{
96 Klein et al, supra note 91, at 309-10.

97 Lester G. Telser, Why Should Manufacturers Want Fair Trade?, 3 J.L. \& ECON. 86 (1960).

98 Id. at 91-92. Although the problems associated with free riding and hold up bear many similarities, they are in fact analytically distinct. Free riding is a result of externalities and derives from the inability of each firm to intemalize all of its costs and benefits. As a result, it is endemic to all markets without well-defined property rights. The possibility of hold up typically arises when a firm must make a relationship-specific investment. The danger of opportunism does not appear until after this investment is made. As such, it is not endemic to the market itself, but rather is a product of a particular investment decision, which explains why the literature refers to the gains as "quasi-rents," as opposed to true rents. In addition, since hold up does not depend upon any notion of externalities, it can occur even in markets with well-defined property rights.
}

99 BORK, supra note 70, at 290-91; POSNER, supra note 69, at 148-50; Robert Bork, The Rule of Reason and the Per Se Concept: Price Fixing and Market Division, 75 YALE L.J. 373, 453-54 
Such contracts can be quite expensive to negotiate and enforce, however, and are inevitably incomplete. If the transaction costs become sufficiently large, a manufacturer might instead choose to obviate the entire problem by vertically integrating into distribution.

Adverse Selection. The third example of opportunistic behavior is known in the literature as "adverse selection." In the context of manufacturing and distribution, it typically arises when products are nonhomogeneous and the manufacturer is unable to determine the value of its products easily. Customers facing such a situation have the incentive to expend a great deal of costs searching through the goods in an attempt to find the goods that are relatively underpriced. The seller will in turn have the incentive to expend additional funds sorting its goods, in order to avoid being left with an inventory comprised solely of below-average goods. These difficulties in determining product quality can thus lead to wasteful expenditure of resources, which Roy Kenney and Benjamin Klein call "oversearching." 100

The parties can avoid these costs, however, either by vertically integrating or by agreeing to a vertical contractual constraint, such as a long-term exclusive dealing arrangement, that functionally serves the same purposes. ${ }^{101}$ In addition, Kenney and Klein suggest that a manufacturer may mitigate oversearching by selling its goods in bundles. The logic is that bundling goods directs the parties' attention away from the value of individual items, which is information that is extremely expensive to obtain, and instead focuses attention on the average value of the entire bundle, which is information that that can be gleaned more cheaply. Bundling, therefore, can reduce transaction costs by decreasing the parties' incentives to expend additional effort in sorting through the goods since, on average, the overpriced and underpriced goods in the bundle tend to balance each other out. ${ }^{102}$

As Kenney and Klein point out, bundling of goods is quite common. Take, for example, the supermarkets' common practice of selling groups of potatoes in opaque plastic bags. If the supermarket were to offer a bin of potatoes for individual sale at a specified price, purchasers would have the incentive to sort through the bin to find the best potatoes (i.e., potatoes that are underpriced, in that their value exceeds the average value of the bin).

(1966) [hereinafter Bork, Rule of Reason]; Robert H. Bork, Vertical Restraints: Schwinn Overruled, 1977 SUP. CT. REV. 171, 180-81 [hereinafter Bork, Vertical Restraints]; Frank H. Easterbrook, Vertical Arrangements and the Rule of Reason, 53 ANTITRUST L.J. 135, 148-50 (1984); Richard A. Posner, Antitrust Policy and the Supreme Court: An Analysis of the Restricted Distribution, Horizontal Merger and Potential Competition Decisions, 75 COLUM. L. REV. 282, 283-85 (1975).

100 Roy W. Kenney \& Benjamin Klein, The Economics of Block Booking, 26 J.L. \& ECON. 497, 503-04 (1983).

101 See supra note 24 and accompanying text.

102 See Kenney \& Klein, supra note 100, at 505. 
The initial purchasers who find such potatoes receive a windfall. Later purchasers will find a bin composed entirely of potatoes that are worth less than the average price of the bin. A seller who wishes to avoid being left with a bin full of low-quality goods can either charge less than the average price or can attempt to sort the potatoes in advance and price them appropriately. Such efforts are costly. Furthermore, additional sorting is unlikely to eliminate this problem, since even if potatoes of different grades are placed into separate bins, the same effect will occur within each bin, albeit on a smaller scale. Prepackaging the potatoes into preset bundles may deal with this problem more effectively, since doing so reduces the incentives to oversearch by making information about quality harder to determine and by refocusing purchasers' attention towards the average quality of the goods. ${ }^{103}$

Kenney and Klein also used examples directly relevant to media markets to illustrate their point. The one that has garnered the most attention is their discussion of the movie studios' practice of "block booking," which was struck down by the Supreme Court in United States v. Paramount Pictures, Inc. ${ }^{104}$ This practice prevented movie theaters from licensing individual films and instead required them to purchase packages of films arranged by the studio.

According to Kenney and Klein, block booking served two distinct purposes. First, it reduced the costs of distributing first-run movies. The practice stems in large part from the difficulty in determining the true value of a movie at the time it is initially licensed. The complexities of scheduling theaters generally required that licensing agreements be signed before the film was produced. Even when that was not the case, advance screenings did not yield much useful information, since consumer response to particular films remained unpredictable. ${ }^{105}$ According to Kenney and Klein, Paramount used block booking to reduce the transaction costs of distributing first-run movies by allowing the movie studios to lower the expenses associated with scheduling movies for release. ${ }^{106}$

Second, block booking solved adverse selection problems in the market for second-run films. A movie's initial run, of course, tended to reveal a movie's real value. Armed with knowledge that was unavailable ex ante, movie theaters have the incentive to accept only those films known ex post to be underpriced (i.e., whose value exceeds the value of the average film) and to reject or shorten the run of those films known ex post to be overpriced (i.e., whose value falls below the value of the average film). Kenney and Klein argued that block booking could

103 See id. at 515.

104334 U.S. 131 (1948).

105 See Kenney \& Klein, supra note 100, at 518, 520-21.

106 Id. at 521. 
eliminate these incentives by preventing theater owners from opportunistically attempting to renegotiate deals based on the new information and by redirecting the focus of both parties to the average price. ${ }^{107}$ If block booking contracts become subject to renegotiation or too expensive to enforce, firms may find it preferable to vertically integrate into distribution.

The Empirical Evidence on Transaction Costs. The transaction cost approach pioneered by the Chicago School was thus able to offer a number of theoretical explanations of why vertical integration might enhance efficiency and was able to identify several specific examples that appeared to confirm these theories. Establishing that something is possible, however, does nothing to establish whether something is likely. As a result, economists have conducted extensive empirical studies in an attempt to determine whether and how frequently such transaction cost efficiencies actually exist. ${ }^{108}$ Although many of these results are promising, they are not sufficient to establish whether vertical integration actually produces the transaction cost efficiencies described in the theoretical literature.

Other studies challenged the historical examples upon which the proponents of particular theories of transaction cost efficiencies have based their claims. For example, a number of distinguished scholars, including Ronald Coase himself, have challenged the Klein-CrawfordAlchian account of Fisher Body. These critics argue that vertical contractual restraints were more than sufficient to protect GM's interests and point out that at the time that Fisher Body supposedly acted opportunistically, GM already owned sixty percent of Fisher Body's common stock. ${ }^{109}$ Klein, in turn, responded by arguing that the relevant quasi-rents resulted from firm-specific human (rather than physical) capita ${ }^{110}$ and by placing greater emphasis on Fisher Body's supposed refusal to locate its plants near GM's. ${ }^{11}$

107 Id. at 521-23.

108 For surveys of the empirical literature on transaction costs and vertical integration, see Keith J. Crocker \& Scott E. Masten, Regulation and Administered Contracts Revisited: Lessons from Transaction-Cost Economics for Public Utility Regulation, 9 J. REG. ECON. 5, 14-15 (1996); Paul L. Joskow, Asset Specificity and the Structure of Vertical Relationships: Empirical Evidence, 4 J.L. ECON. \& ORG. 95, 107-11 (1988); Perry, supra note 72, at 215-19; Aric Rindfleisch \& Jan B. Heide, Transaction Cost Analysis: Past. Present, and Future Applications, 61 J. MARKETING 30, 32-39 (1997); and Howard A. Shelanski \& Peter G. Klein, Empirical Research in Transaction Cost Economics: A Review and Assessment, 11 J.L. ECON. \& ORG. 334, 349-50 (1995).

109 See generally Ramon Casadesus-Masanell \& Daniel F. Spulber, The Fable of Fisher Body, 43 J.L. \& ECON. 67 (2000); R.H. Coase, The Acquisition of Fisher Body by General Motors, 43 J.L. \& ECON. 15 (2000); R.H. Coase, The Nature of the Firm: Meaning, 4 J.L. ECON. \& ORG. 19, 3031 (1988); Robert F. Freeland, Creating Holdup Through Vertical Integration: Fisher Body Revisited, 43 J.L. \& ECON. 33 (2000).

110 Benjamin Klein, Vertical Integration as Organizational Ownership: The Fisher BodyGeneral Motors Relationship Revisited, 4 J.L. ECON. \& ORG. 199, 204-08 (1988). 105 (2000).

111 Benjamin Klein, Fisher-General Motors and the Nature of the Firm, 43 J.L. \& ECON. 
Another set of commentators has challenged Kenney and Klein's account of the Paramount case. Block booking can only reduce transaction costs if the licensing agreement prevents theater owners from renegotiating the terms of the contract after the true value of the films has been revealed. Andrew Hanssen effectively undercut Kenney and Klein's analysis by demonstrating that the typical block booking contract permitted theater owners to reject a significant number of second-run films and that the movie studios often did not force theater owners to fulfill all of their block booking obligations. ${ }^{12}$ Kenney and Klein, in turn, responded with an alternative account of the Paramount case. According to this new account, the parties relied on self enforcement, regulated by the mutual need to preserve reputational capital, rather than the provisions of the contract to protect themselves against opportunistic behavior. The real purpose of the contract was to provide a safety net to guard against the failure of such self enforcement. As a result, Kenney and Klein argued that it is not surprising that the parties occasionally deviated from the strict contract terms. ${ }^{113}$

It appears that the critics have gained the upper hand in these debates, a development made important because of the manner in which the proponents of the various efficiency theories relied upon the specific examples they cited as the primary support for their plausibility. These empirical disputes cannot completely resolve these issues, however. Even though subsequent work has called the specific examples cited into question as an empirical matter, the falsification of these particular examples does not necessarily invalidate these proposals as a theoretical matter. As Timothy Muris, the recently appointed Chairman of the FTC, has observed, the principal empirical questions surrounding the transaction cost implications of vertical integration and vertical restraints have yet to be resolved. ${ }^{114}$

It would, however, be a mistake to suggest that the unavailability of definitive empirical proof of the existence of such efficiencies renders the (2000)

112 F. Andrew Hanssen, The Block Booking of Films Reexamined, 43 J.L. \& ECON. 395

113 Roy W. Kenney \& Benjamin Klein, How Block Booking Facilitated Self-Enforcing Film Contracts, 43 J.L. \& ECON. 427, 430-32 (2000).

114 Timothy J. Muris, GTE Sylvania and the Empirical Foundations of Antitrust, 68 ANTITRUST L.J. 899, 910-11 (2001); see also Eddie Correia, Antitrust Policy After the Reagan Administration, 76 GEO. L.J. 329, 331 (1987) (noting that the empirical evidence for "the most fundamental assumptions" underlying economic policy are "often very thin"); William H. Page, The Chicago School and the Evolution of Antitrust: Characterization, Antitrust Injury, and Evidentiary Sufficiency, 75 VA. L. REV, 1221, 1242 (1989) (observing that Chicago School studies "do not resolve many of the most basic empirical questions associated with the policy choices that the [Chicago] models pose"); $i d$. at 1252 (noting that "[t]he state of empirical research" on resale price maintenance "is inadequate to resolve the dispute"). These issues are rendered even murkier by the argument that even when opportunism emerges as a real problem, the parties might look to governmental regulation to ensure that the various parties do not take advantage of one another. See Victor P. Goldberg, Regulation and Administered Contracts, 7 BELL J. ECON. 426 (1976). 
Chicago School's efficiency arguments unimportant. The mere possibility that such efficiencies might exist raises serious questions about the appropriateness of treating vertical integration as illegal per se. As the Court has noted, per se illegality is appropriate only if the practice is so pernicious and lacking in redeeming value that nothing would be lost if it were presumed to be illegal without any examination of the facts of a particular case. ${ }^{115}$ Chicagoans maintained that even if they could not establish that such efficiencies existed in all cases, they had at least raised a sufficient possibility that such efficiencies might exist to justify evaluating vertical integration under the case-by-case approach associated with the rule of reason. ${ }^{116}$ Even those who question whether vertical integration is likely to lead to widespread transaction cost savings will still pause before embracing the presumption that vertical integration is sufficiently likely to harm competition to justify embracing a blanket prohibition of the practice.

\section{d. The Impact of the Chicago School Critique}

Although the Chicago School began as "little better than a lunatic fringe," 117 its attack on the existing orthodoxy regarding vertical integration ultimately proved transformative. Mainstream antitrust scholars have now largely accepted the Chicago School's critiques of the Harvard School's reliance on leverage and foreclosure theory. ${ }^{118}$ The Supreme Court has followed suit, on some occasions overruling precedents holding various vertical restraints to be illegal per $\mathrm{se}^{119}$ and on other occasions accomplishing essentially the same result by requiring plaintiff's to establish the existence of the structural preconditions discussed above before subjecting the restraint to antitrust scrutiny. ${ }^{120}$

115 See N. Pac. Ry. Co. v. United States, 356 U.S. 1, 5 (1958).

116 See Bork, Rule of Reason, supra note 99, at 453-54; Frank H. Easterbrook, Maximum Price Fixing, 48 U. CHI. L. REV. 886 (1981); Easterbrook, Vertical Arrangements, supra note 99, at 153; Richard A. Posner, The Rule of Reason and The Economic Approach: Reflections on the Sylvania Decision, 45 U. CHI. L. REV. 1 (1977).

117 Posner, supra note 67, at 931 .

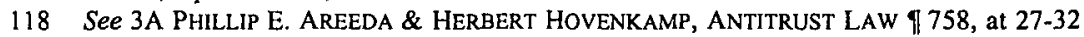
(1996); 4 Phillip AREeda \& DonAld F. TURNer, ANTITRUST LAW I 1004, at 222 (1980); HOVENKAMP, supra note 52, $\S 7.6 \mathrm{~b}$, at 301-02; Richard S. Markovits, Tie-Ins and Reciprocity: $A$ Functional, Legal, and Policy Analysis, 58 TEX. L. REV. 1363, 1363-1410 (1980); Richard S. Markovits, Tie-ins, Leverage, and the American Antitrust Laws, 80 YALE L.J. 195, 199-205 (1970); Oliver E. Williamson, Delimiting Antitrust, 76 GEO. L.J. 271, 282 (1987).

119 See State Oil Co. v. Khan, 522 U.S. 3 (1997) (maximum resale price maintenance); Continental T.V., Inc. v. GTE Sylvania Inc., 433 U.S. 36 (1977) (vertical territorial restrictions); see also Barry Wright Corp. v. ITT Grinnell Corp., 724 F.2d 227, 236-37 (1st Cir. 1983) (Breyer, J.) (concluding that exclusive dealing contracts are now governed by the rule of reason).

120 See Eastman Kodak Co. v. Image Technical Servs. Inc., 504 U.S. 451, 481 (1992) (concluding that monopolization requires proof of monopoly power in primary market); Northwest Wholesale Stationers, Inc. v. Pac. Stationery \& Printing Co., 472 U.S. 284, 296-97 (1985) (holding that 
The ultimate testament to the triumph of the Chicago School's precepts is the Justice Department's Vertical Merger Guidelines. Promulgated in $1984^{121}$ and apparently still in force today, ${ }^{122}$ the Vertical Merger Guidelines embrace the structural preconditions identified by the Chicago School as essential to proving that a vertical merger is likely to have an anti-competitive effect. First, the Guidelines require that the primary market must be concentrated. The Guidelines measure the degree of market concentration by using the Hirschman-Herfindahl index ("HHI"), ${ }^{123}$ which has become the standard concentration measure for antitrust enforcement purposes. The Guidelines indicate that the antitrust authorities are unlikely to challenge a vertical merger unless HHI in the primary market exceeds 1800 , which is the level of concentration that would result in a market comprised of somewhere between five and six equal competitors. ${ }^{124}$ Second, the Guidelines require that the secondary

requires proof of market power in primary market and substantial foreclosure of secondary market); $c f$. Spectrum Sports, Inc. v. McQuillan, 506 U.S. 447, 459 (1993) (stating that antitrust laws regard "the conduct of a single firm unlawful only when it actually monopolizes or dangerously threatens to do so").

121 See 49 Fed. Reg. 26,823 (1984)

122 The 1992 statement that accompanied the issuance of new Horizontal Merget Guidelines indicated that Section 4 of the 1984 Guidelines continued to provide the relevant guidance for vertical mergers. See U.S. Department of Justice \& Federal Trade Commission, Non-Horizontal Merger Guidelines, 57 Fed. Reg. 41,552 (1992), available at http://www.usdoj.gov/atr/public/ guidelines/2614.htm. The Clinton Administration did consider adjusting the Vertical Merger Guidelines, but did not do so, as evidenced by the fact that the Guidelines continue to appear on the Justice Department's website. As a result, legal commentators have uniformly indicated that the Vertical Merger Guidelines remain in force. See, e.g., M. Howard Morse, Vertical Mergers: Recent Learning, 53 BuS. LAw. 1217, 1224 (1998). For a review of the recent increase in vertical merger enforcement actions, see $i d$. at $1226-45$.

$123 \mathrm{HHI}$ is a measurement of market concentration that is calculated by squaring the market share of each competitor and then summing the resulting numbers. For example, a market of four firms with market shares of $30 \%, 30 \%, 20 \%$ and $20 \%$, respectively, would have an HHI of $30^{2}+30^{2}+20^{2}+$ $20^{2}=900+900+400+400=2600$. The result is a continuum that rates the concentration of a market on a scale from 0 (in the case of complete market deconcentration) to 10,000 (in the case of monopoly).

124 Non-Horizontal Merger Guidelines, supra note 122, $§ 4.213$. The Vertical Merger Guidelines reserve the possibility of challenging mergers at lower HHI levels if "effective collusion is particularly likely." Id. Because vertical mergers are less likely than horizontal mergers to create competitive problems, the Vertical Merger Guidelines apply a somewhat more liberal standard than that applied to horizontal mergers. Id. $\S 4.0$. The Horizontal Merger Guidelines classify markets in which the post-merger $\mathrm{HHI}$ is below 1000 as "unconcentrated." Horizontal mergers in such markets are ordinarily not subject to challenge. U.S. Department of Justice \& Federal Trade Commission, 1992 Horizontal Merger Guidelines $\S 1.51(\mathrm{a}), 57$ Fed. Reg. 41,552 (1992), revised, 4 Trade Reg. Rep. (CCH) I13,104 (Apr. 8, 1997), available at http://www.usdoj.gov/atr/public/guidelines/horiz_book/ hmgl.html. Markets in which the post-merger HHI is between 1000 and 1800 are "moderately concentrated." Horizontal mergers in markets that fall within this range "potentially raise significant competitive concerns" and may be subject to challenge if they increase HHI by more than 100 points. Id. $\S 1.51(\mathrm{~b})$. The Horizontal Merger Guidelines treat markets in which the post-merger HHI exceeds 1800 as "highly concentrated." In these markets, mergers that raise post-merger HHI by more than 50 points "potentially raise significant competitive concerns" and may be challenged. Mergers that raise post-merger HHI 100 points are "presumed ... to create or enhance market power or facilitate its exercise" and are likely to be challenged. $I d$. $\$ 1.51(\mathrm{c})$. Interestingly, even if measured against the more 
market also be concentrated as well as protected by barriers to entry. ${ }^{125}$ Lastly, even if those preconditions are met, the Guidelines recognize that the presence of significant efficiencies might nonetheless justify permitting a vertical merger to go forward even when the market structure raises the possibility that the merger might have some anti-competitive effects. ${ }^{126}$

Not content with these victories, the Chicago School proponents urged that the regulators subject vertical integration to even greater deference. Specifically, Chicagoans believed that they had completely discredited any possibility that a vertical merger could have any anticompetitive effects. In the absence of any plausible harm to competition, these theorists posited that all instances of vertical integration must be motivated by the desire to realize pro-competitive efficiencies. As a result, it was not sufficient simply to move from the preexisting world of per se illegality to the rule of reason. Instead, they contended that it would be appropriate to go so far as to treat vertical integration as per se legal. ${ }^{127}$

\section{The Post-Chicago School's Rejection of Per Se Legality}

The Chicago School's call for regarding vertical integration as legal per se in turn inspired a new generation of scholars known as the postChicago School. ${ }^{128}$ Unlike the Chicago School's previous critics, postChicago scholars accept economic efficiency as the goal of antitrust. ${ }^{129}$ They parted company with Chicagoans, however, by rejecting the static nature of the price theoretic models that provided the foundation for

stringent standards applied to horizontal mergers, most of the markets under consideration in this Article are too unconcentrated to permit any firm to use mergers to threaten competition.

125 Non-Horizontal Merger Guidelines, supra note $122, \S 4.212$.

126 Id. $\$ 4.24$.

127 See, e.g., BORK, supra note 70, at 226, 231. Chicago School theorists offered similar views with respect to vertical restraints. See id. at 288 ("Analysis shows that every vertical restraint should be completely lawful."); Bork, Rule of Reason, supra note 99, at 397 ("The thesis advanced here is that every vertical arrangement should be lawful."); Bork, Vertical Restraints, supra note 99, at 181-82 ("A A]ntitrust should have no concern with vertical restraints; all should be lawful."); Richard A. Posner, The Next Step in the Antitrust Treatment of Restricted Distribution: Per Se Legality, 48 U. CHI. L. REV. 6, 22-25 (1981) ("best to declare that purely vertical restraints on intrabrand competition ... legal per se"); see also POSNER, supra note 69, at 182 (advocating per se legality of tying contracts).

128 For overviews of the post-Chicago School, see Jonathan B. Baker, Recent Developments in Economics that Challenge Chicago School Views, 58 ANTITRUST L.J. 645 (1989); Herbert Hovenkamp, Antitrust Policy After Chicago, 84 MiCH. L. REV. 213 (1985) [hereinafter Hovenkamp, After Chicago]; Herbert Hovenkamp, Post-Chicago Antitrust: A Review and Critique, 2001 CoLuM. BUS. L. REV. 257 (2001) [hereinafter Hovenkamp, Post-Chicago]; Michael S. Jacobs, An Essay on the Normative Foundations of Antitrust Economics, 74 N.C. L. REV. 219 (1995); and Michael W. Klass \& Michael A. Salinger, Do New Theories of Vertical Foreclosure Provide Sound Guidance for Consent Agreements in Vertical Merger Cases?, 40 ANTITRUST BULL. 667 (1995).

129 See Baker, supra note 128 , at 646 ; Jacobs, supra note 128 , at 222,242 . As Carl Shapiro so colorfully put it, "If 'Post-Chicago Economics' stands for the notion that . . . antitrust should move away from promoting efficiency and consumer welfare, count me out." Carl Shapiro, Aftermarkets and Consumer Welfare: Making Sense of Kodak, 63 ANTITRUST L.J. 483, 484 (1995) (footnote omitted). 
Chicago School scholarship. ${ }^{130}$ Instead, they employed game theory and other methods for modeling strategic behavior to study the impact of vertical integration when markets function imperfectly. These tools enabled them to identify circumstances under which firms have the ability to use the leverage provided by a dominant position in one market to harm competition. $^{131}$ The existence of formal models showing potential anticompetitive effects arising from vertical relationships served as a powerful rebuttal to the Chicago School's call for treating vertical integration and vertical restraints as legal per se. It is my hope to lay out a more complete analysis of the post-Chicago theories of vertical integration elsewhere. In addition, Part III will specifically address some particular attempts to apply post-Chicago principles to vertical integration in the cable modem industry. ${ }^{132}$ For the time being, it is sufficient to restrict myself to a few observations.

First and foremost, notwithstanding the significant differences between these two schools of thought, a close examination of the postChicago literature reveals the existence of some common ground. Most important for the purposes of this Article is the fact that the post-Chicago theories of vertical integration either explicitly or implicitly rely on the existence of the same structural preconditions identified by the Chicago School. Specifically, the post-Chicago scholarship models typically model the relevant markets either as dominant firm industries ${ }^{133}$ or as oligopolistic markets undergoing Cournot or Bertrand competition. ${ }^{134}$ Both of these approaches essentially require that the relevant markets be highly concentrated and protected by barriers to entry. ${ }^{135}$ In the absence of such

130 Hovenkamp, After Chicago, supra note 128, at 256; Kaplow, supra note 61, at 527-31; William E. Kovacic, The Antitrust Paradox Revisited: Robert Bork and the Transformation of Modern Antitrust Policy, 36 WAYNE L. REV. 1413, 1465 (1990); Williamson, supra note 52, at 299-30l.

131 See, e.g., Oliver Hart \& Jean Tirole, Vertical Integration and Market Foreclosure, BROOKINGS PAPERS ON ECONOMIC ACTIVITY: MICROECONOMICS 205 (1990); Janusz A. Ordover et al., Equilibrium Vertical Foreclosure, 80 AM. ECON. REV. 127 (1990); Michael H. Riordan, Anticompetitive Vertical Integration by a Dominant Firm, 88 AM. ECON. REV. 1232 (1998); Michael H. Riordan, \& Steven C. Salop, Evaluating Vertical Mergers: A Post-Chicago Approach, 63 ANTITRUST L.J. 513 (1995); Michael A. Salinger, Vertical Mergers and Market Foreclosure, 103 Q.J. ECON. 345 (1988); Steven C. Salop \& David T. Scheffman, Raising Rivals' Costs, 73 AM. ECON. REV. 267,268 (1983).

132 See infra Subsection III.B.4.

133 See, e.g., Hovenkamp, Post-Chicago, supra note 128, at 325-26; Salop \& Scheffman, supra note 131 , at 267 .

134 See, e.g., Hart \& Tirole, supra note 131; Ordover et al., supra note 131; Riordan \& Salop, supra note 131; Salinger, supra note 131.

135 Dominant firm industries are generally defined as those in which the largest firm has at least a sixty percent share and into which entry is not easy. See, e.g., Oliver E. Williamson, Assessing Vertical Market Restrictions: Antitrust Ramifications of the Transaction Cost Approach, 127 U. PA. L. REV. 953, $965 \mathrm{n.50}$ (1979). Coumot and Bertrand models similarly assume that entry is impossible and that market concentration is directly linked to anti-competitive effects. See, e.g., DENNIS W. CARLTON \& JeFFrey M. PERLOFF, MODERN INDUSTRIAL ORGANIZATION 157, 165, 167, 175 (3d ed. 1999); JEFFREY CHURCH \& ROGER WARE, INDUSTRIAL ORGANIZATION 233-40, 247-52, 256-57 (2000). See 
structural features, the formal models recognize that vertical integration may be just as likely to lower price and increase welfare and that the ability of existing players or new entrants to expand their outputs will be sufficient to defeat any attempt to increase price above competitive levels. ${ }^{136}$

Furthermore, post-Chicago theorists generally accept the Chicago School position that, even when the market structure is conducive to leveraging, vertical integration may lead to efficiencies sufficient to offset any concomitant anti-competitive effects and that whether a particular instance of vertical integration impedes or promotes competition depends on which of these two effects dominates. ${ }^{137}$ In fact, the parallels between their recognition that vertical integration can promote welfare either by eliminating the problems of double marginalization ${ }^{138}$ or by minimizing transaction $\operatorname{costs}^{139}$ and the Chicago School arguments detailed above are striking. Thus, as post-Chicago theorists candidly acknowledge, the existence of potential efficiencies makes it impossible to take an a priori stance of hostility or non-hostility towards vertical integration. ${ }^{140}$

For the purposes of this Article, then, it is sufficient to draw two limited conclusions. First, since regulations of the type at issue in this Article prohibit vertical integration without any inquiry into the specific facts of the case, those regulations necessarily presuppose that the proper

generally Bhagwat, supra note 21, at 1488; Hovenkamp, After Chicago, supra note 128, at 274, 275 n.291; Herbert Hovenkamp, Antitrust Policy, Restricted Distribution, and the Market for Exclusionary Rights, 71 MINN. L. REv. 1293, 1301 n.37, 1302, 1310-11 (1987); Hovenkamp, Post-Chicago, supra note 128, at 324-25; Janusz A. Ordover, Predation, Monopolization, and Antirust, in 1 HANDBOOK OF INDUSTRIAL ORGANIZATION, at 537, 566; Williamson, supra note 118, at 293. For critics offering the same observation, see Edward A. Snyder \& Thomas E. Kauper, Misuse of the Antitrust Laws: The Competitor Plaintiff, 90 MICH. L. REv. 551, 564, 566 (1991).

136 See Riordan \& Salop, supra note 131, at 532-33; Michael A. Salinger, Vertical Mergers in Multi-Product Industries and Edgeworth's Paradox of Taxation, 39 J. INDUS. ECON. 545 (1991). It should be noted that there is one family of post-Chicago models that does not necessarily depend upon the existence of market power in the relevant markets. These models turn on the possibility that a strategizing firm could use tying or some other form of vertical restraint to force other players below minimum viable scale. See, e.g., Michael D. Whinston, Tying, Foreclosure, and Exclusion, 80 AM. ECON. REV. 837 (1990). Such models have little relevance to the contexts addressed by this Article, since minimum viable scale in the industries discussed in this Article tend to be too low to make this a viable strategy. See, e.g., Time Warner Entm't Co. v. FCC, 240 F.3d 1126, 1130-39 (D.C. Cir.), cert. denied, 122 S. Ct. 644 (2001).

137 See, e.g., IAN AYRES, VERTICAL INTEGRATION AND OVERBUYING: AN ANALYSIS OF Foreclosure VIa RAISED Rivals' CoSTS 17-20, 23-24 (Am. Bar Found., Working Paper No. 8803, 1988); Hart \& Tirole, supra note 131 , at 212 ; Klass \& Salinger, supra note 128 , at $679-82$; Riordan \& Salop, supra note 131 , at 522-27, 544-51, 564; Salinger, supra note 131, at 349-50; see also Thomas G. Krattenmaker \& Steven C. Salop, Anticompetitive Exclusion: Raising Rivals' Costs to Achieve Power Over Price, 96 YALE L.J. 209, 277-80 (1986) (conducting a similar analysis with respect to vertical restraints).

138 See Riordan \& Salop, supra note 131, at 526-27; Salinger, supra note 131, at 354-55.

139 See Klass \& Salinger, supra note 128, at 673; Williamson, supra note 135.

140 See Riordan \& Salop, supra note 131, at 526-27; Salinger, supra note 131, at 349-50; see also Hovenkamp, Post-Chicago, supra note 128, at 352-56. 
stance with respect to vertical integration is one of per se illegality. ${ }^{141}$ Although Chicagoans and post-Chicagoans disagree over the nature and frequency of the circumstances under which vertical integration can harm competition, they agree that vertical integration often enhances welfare. As a result, nothing in the debate provides any support for a return to the discredited Harvard School position of treating vertical integration as illegal per se.

Second, the debate between the Chicago and the post-Chicago Schools only seems to confirm the value of continuing to follow the basic approach taken by the Vertical Merger Guidelines, since both approaches seem to highlight the importance of focusing on market concentration, barriers to entry, and the potential for welfare-enhancing efficiencies. ${ }^{142}$ The post-Chicagoans' only quibble appears to be with the HHI levels used to demarcate when a market is sufficiently concentrated as to create a risk of anti-competitive danger. ${ }^{143}$ Such concerns are mitigated in large part by these scholars' embrace of the Vertical Merger Guidelines when defending the administrability of their theories, ${ }^{144}$ their apparent willingness to apply the HHI thresholds appearing in the Guidelines, ${ }^{145}$ and their reticence in proposing an alternative numerical standard. ${ }^{146}$

Thus, notwithstanding the considerable divergence of opinion between the Chicago School and the post-Chicago School on a wide range of issues, the situations identified by the post-Chicago School in which vertical integration can harm competition reinforce, rather than undercut, the appropriateness of continuing to rely on the Vertical Merger Guidelines as a basis for determining whether a vertical merger is likely to harm competition. Although many questions remain with respect to vertical integration, the Guidelines continue to represent the underlying economic consensus and as a result constitute an appropriate starting point for evaluating the effect that vertical integration is likely to have on competition.

141 Professor Louis Kaplow's pathbreaking analysis of the Chicago School's critique of leveraging is not to the contrary. By identifying particular circumstances in which leverage could harm competition, his article was meant to "establish[] only that leverage must be taken seriously; other explanations offered by the critics of leverage theory to explain restrictive practices are not ruled out." Kaplow, supra note 61 , at 516.

I 42 See Riordan \& Salop, supra note 131, at 533, 540-41 (noting that their approach called for a structural evaluation of concentration and barriers to entry similar to that followed by the Vertical Merger Guidelines); see also Krattenmaker \& Salop, supra note 137, at 284-85 (calling their theory "broadly consistent" and "fundamentally consistent" with the Vertical Merger Guidelines).

143 See Krattenmaker \& Salop, supra note 137, at 284-85.

144 See id. at 255-58, 289.

145 See id. at 261-62 (referring to HHI levels of " 1000 (or 1800)").

146 See Klass \& Salinger, supra note 128 , at $682-83$ (noting that one post-Chicago model suggests that another numerical standard might be appropriate without suggesting any alternative). 


\section{Applying the Basic Economic Framework to the Chain Broadcasting Rules}

The tripartite approach taken by the Vertical Merger Guidelines thus provides an appropriate basis for evaluating whether vertical integration can plausibly pose the threat to competition that the FCC envisioned when it enacted the Chain Broadcasting Rules. As noted earlier, the FCC's central concerns were that the broadcast networks would be able to use their dominance over the wholesale level of production to harm competition at the retail level of production and to lock up local broadcast stations in ways that would forestall the emergence of new networks. Under the framework established by the Vertical Merger Guidelines, the market for networks represents the primary market, and the market for broadcast stations represents the secondary market. For vertical integration to pose a sufficient danger, then, (1) the market for networks must be concentrated, (2) the market for broadcast stations must also be concentrated and protected by barriers to entry, and (3) there must be no plausible efficiencies resulting from network ownership of broadcast stations. A systematic evaluation of each of these criteria reveals that none of them are met. As such, under the Guidelines approach, vertical integration between broadcast networks and local broadcast stations is insufficiently likely to produce the type of anti-competitive effects that would justify imposing a blanket prohibition on vertical integration of the type embodied in the Chain Broadcasting Rules.

\section{Concentration in the Market for Television Networks}

The first step in determining whether vertical integration between broadcast networks and broadcast stations will have anti-competitive effects is evaluating whether the market for networks is concentrated. The key to evaluating the degree of concentration in a particular market is product market definition. As the D.C. Circuit has noted, "entertainment is an industry in which antitrust concepts such as product market ... are exceptionally difficult to apply." ${ }^{147}$ Policymakers and commentators have long debated whether such alternative media as print and videocassette recorders should be regarded as substitutes for broadcast programming. ${ }^{148}$

147 National Ass'n of Theater Owners v. FCC, 420 F.2d 194, 204 (D.C. Cir. 1969), cert. denied, 397 U.S. 922 (1970)

148 See Syracuse Peace Coun., 2 F.C.C.R. 5043, 5053-54, If 66-72 (1987) (Memorandum Opinion and Order); Inquiry into Section 73.1910 of the Comm'n's Rules and Regulations Concerning the Gen. Faimess Doctrine Obligations of Broad. Licensees, 102 F.C.C.2d 142, 198-219, If 85-128 (1985) (Report); Amendment of Section 73.3555, [formerly Sections 73.35, 73.240, and 73.636] of the Comm'n's Rules Relating to Multiple Ownership of AM, FM and Television Broad. Stations, 100 F.C.C.2d 17, 25-26, ๆ $25-26$ (1984) (Report and Order); Amendment of Sections 73.35, 73.240, and 
I leave resolution of such complex issues for another day. To simplify the analysis, I will take the less controversial tack of focusing solely on alternative sources of television programming that more clearly represent substitutes for the original broadcast television networks.

Even the casual observer is no doubt well aware that the market for television broadcast networks has undergone a significant degree of deconcentration in recent years. The last fifteen years have witnessed the arrival of Fox as a fourth major television network strong enough to produce such hit shows as "The Simpsons" and "The X-Files" as well as capture such marquee properties such as the NFL. Three other fledgling networks-UPN, WB, and PaxTV—have also joined the fray. In addition, the last thirty years have witnessed an explosion of independent television stations that offer still more programming in direct competition with the broadcast networks. ${ }^{149}$ As a result, even if the relevant market were limited solely to the market for broadcast television, it appears that the market is too unconcentrated to permit the networks to harm competition in the market for local television stations. ${ }^{150}$

It is likely, however, that restricting our focus to other broadcast television networks would be too narrow. Proper market definition requires the inclusion of products that act as substitutes for broadcast networks as well. It now seems relatively clear that broadcast television networks compete directly with television networks transmitted via cable, direct broadcast satellites ("DBS"), and similar technologies (which the federal statutes term multichannel video programming distributors or "MVPDs"). ${ }^{151}$ As the FCC's most recent Annual Report on Competition in Video Markets reveals, cable television is now essentially universally available, with cable lines passing ninety-seven percent of all households nationwide, ${ }^{152}$ and DBS is available to any home with a clear line of sight

73.636 of the Comm'n's Rules Relating to Multiple Ownership of AM, FM and Television Broad. Stations, 95 F.C.C.2d 360, 387-89 \& n.101 (1983) (Notice of Proposed Rulemaking); JONATHAN LEVY \& FLORENCE SETZER, MEASUREMENT OF CONCENTRATION IN HOME VIDEO MARKETS 51-53 (FCC Off. of Plans \& Policy Staff Report, Dec. 23, 1982); Lawrence P. Blaskopf, Note, Defining the Relevant Product Market of the New Video Technologies, 4 CARDOZO ARTS \& ENT. L.J. 75 (1985); Harry Boadwee, Note, Product Market Definition for Video Programming, 86 COLUM. L. REV. 1210, $1210 \&$ nn.3-4 (1986).

149 Review of the Prime Time Access Rule, II F.C.C.R. 546, 560-61, If 27-29 (1995) (Report and Order).

150 See id. at 562 n.64 (noting that the $\mathrm{HHl}$ for national prime-time broadcast television program distribution was 1366 ).

151 For a description of the various MVPDs, which also include home satellite dishes ("HSD"), multichannel multipoint distribution systems ("MMDS"), satellite master antenna television systems ("SMATV"), open video systems ("OVS"), see Annual Assessment of the Status of Competition in the Mkts. for the Delivery of Video Programming, FCC $01-389$, slip op., at 10-54, 71 15-115 (F.C.C. rel. Jan. 14, 2002) (Eighth Annual Report), available at http://hraunfoss.fcc.gov/ edocs_public/attachmatch/FCC-01-389A1.pdf [hereinafter Eighth Annual Report].

152 Id. at 87 tbl.B-1. 
to the sky. ${ }^{153}$ Competition among MVPDs has caused them to routinely waive installation fees and other switching costs and has driven the price of introductory packages to as little as nine dollars per month. ${ }^{154}$ As a result, MVPDs have now overtaken conventional broadcasting as the predominant means for delivering television programming to the home. As Table I indicates, eighty-six percent of U.S. households now receive their television through cable, DBS, or some other MVPD.

\section{Table I. Deployment of Multichannel Video Programming Distribution ("MVPD") Technologies as of June 2001}

\begin{tabular}{lrrr}
\hline MVPD Technology & $\begin{array}{l}\text { Households } \\
\text { (millions) }\end{array}$ & $\begin{array}{l}\text { \% MVPD } \\
\text { Households }\end{array}$ & $\begin{array}{c}\text { \% Total TV } \\
\text { Households }\end{array}$ \\
\hline Cable & & & \\
DBS & 68.98 & $78.11 \%$ & $67.51 \%$ \\
SMATV & 16.07 & $18.20 \%$ & $15.73 \%$ \\
Home Satellite Dish & 1.50 & $1.70 \%$ & $1.47 \%$ \\
MMDS & 1.00 & $1.13 \%$ & $0.98 \%$ \\
Open Video Systems & 0.70 & $0.79 \%$ & $0.69 \%$ \\
& 0.60 & $0.07 \%$ & $0.06 \%$ \\
Total MVPD Households & 88.31 & $100.00 \%$ & $86.42 \%$ \\
Total TV Households & 102.18 & & $100.00 \%$ \\
\hline
\end{tabular}

Source: Eighth Annual Report, supra note 151, at 95 tbl.C-1.

Indeed, the FCC has explicitly recognized that cable and broadcast networks operate as substitutes for one another. For example, in proposing the elimination of the two-year limit on network affiliation agreements enacted by the Chain Broadcasting Rules, the FCC recognized that the emergence of alternative video delivery systems had subjected the

$153 I d$. at 56,7122 . The only significant remaining impediment to MVPD deployment is the inability of cable and DBS operators to reach residents living in large apartment buildings, which the FCC terms multiple dwelling units or MDUs. Id. at 57-60, 91 124-36. The FCC has taken steps to increase MVPD access to MDU residents and is currently considering what additional steps may be necessary. See Promotion of Competitive Networks in Local Telecomms. Mkts., 15 F.C.C.R. 22,983 (2000) (First Report and Order and Further Notice of Proposed Rulemaking in WT Docket No. 99-217, Fifth Report and Order and Memorandum Opinion and Order in CC Docket No. 96-98, and Fourth Report and Order and Memorandum Opinion and Order in CC Docket No. 88-57); Implementation of Section 207 of the Telecomms. Act of 1996, 13 F.C.C.R. 23,874 (1998) (Second Report and Order); Telecomms. Servs. Inside Wiring, 13 F.C.C.R. 3659 (1997) (Report and Order and Second Further Notice of Proposed Rulemaking).

154 See Dish Network, Dish Network Special Offers, at http://www.dishnetwork.com/ content/promotions/index.shtml (last visited Dec. 12, 2001). 
established broadcast networks to increasingly vigorous competition. ${ }^{155}$ The FCC reconfirmed this conclusion when repealing the two-year limit the following year. ${ }^{156}$ Similarly, when eliminating the Chain Broadcasting Rules' prohibition of network ownership of certain local broadcast stations, the FCC relied in part on the emergence of cable and DBS as viable alternatives to conventional over-the-air television broadcasting. ${ }^{157}$ Given the high degree of penetration achieved by the MVPDs and the FCC's recent regulatory decisions recognizing the interchangeability of the various video technologies, it seems relatively clear that cable television, DBS, and other MVPDs should be included in the same product market as conventional broadcasting.

Once cable and the other MVPDs are included in the same product market as broadcast networks, the task becomes one of computing the relevant HHIs. Practical limitations lead me to include only those firms already participating in the relevant markets. The FCC is currently exploring whether focusing solely on current market participants understates the competitiveness of particular markets, since doing so ignores the fact that any attempt to increase price can often induce existing players to expand output as well as attract entry by new firms. ${ }^{158}$ Since any such entry would only increase the competitiveness of the market, calculating HHIs on the basis of the current market can provide a useful baseline for evaluating a market's competitiveness. If HHIs calculated in this manner fall below the HHI thresholds identified by the Vertical Merger Guidelines, there would appear to be little basis for regulatory concern.

Although it is conventional to calculate HHIs using product share, the Guidelines issued by the Justice Department and the FTC to govern horizontal mergers indicate that dollar sales may be more appropriate

155 Review of Rules and Polices Concerning Network Broad. by Television Stations: Elimination or Modification of Section 73.658(c) of the Comm'n's Rules, 3 F.C.C.R. 5681, 5682, ๆf 18 (1988) (Notice of Proposed Rulemaking).

156 See Review of Rules and Policies Concerning Network Broad. by Television Stations: Elimination or Modification of Section 73.658(c) of the Comm'n's Rules, 4 F.C.C.R. 2755, 2757, ๆ 15 (1989) (Report and Order).

157 Review of the Comm'n's Regulations Governing Television Broad., 10 F.C.C.R. 4538, 4540, \ 10 (1995) (Report and Order).

158 Eighth Annual Report, supra note 151, at 65, I 154; see also Horizontal Merger Guidelines, supra note $124, \S 1.32$ (recognizing that well-defined product market includes firms that would enter in response to an increase in price). This revised approach would better incorporate the core insights of "contestability" theory, which recognizes that the threat of potential entry can discipline a market as effectively as competition from current market participants. Even markets that are heavily concentrated may nonetheless be efficient so long as barriers to entry and exit are low. See generally William J. BAUMOL, JOHN C. PANZAR, \& ROBERT D. WILlig, CONTESTABle MarketS AND THE THEORY OF INDUSTRY STRUCTURE (1982). For a compact overview of contestability theory, see Elizabeth E. Bailey \& William J. Baumol, Deregulation and the Theory of Contestable Markets, 1 YALE J. ON REG. 111, 111-22 (1984). 
when products are differentiated. ${ }^{159}$ Consequently, I will estimate HHIs using both dollar and audience share. Several considerations can make calculating HHIs in the television industry quite tricky. Since certain cable networks are jointly owned by several entities, it can be difficult to determine how to attribute ownership interests. ${ }^{160}$ In addition, practical considerations have forced me to base my analysis solely on published, non-proprietary information. The following analysis is thus offered as a rough-and-ready approximation of a true HHI. While a more refined analysis would doubtlessly be better, I believe that these calculations are sufficient to provide a working understanding of whether the market for television networks is sufficiently concentrated to support claims that vertical integration involving that market would harm competition. To give the Chain Broadcasting Rules the widest possible berth, I attempted to resolve all ambiguities in a way that maximized the effect on total HHI.

Although the issue is a close one, analyzed in terms of viewership shares it appears that the market for television networks does not meet the standard of concentration articulated in the Vertical Merger Guidelines to raise the danger that the broadcast networks will be able to exert market power against local broadcast stations. An analysis of the market for television networks in terms of dollar share leads to the same conclusion.

159 Horizontal Merger Guidelines, supra note 124, §1.41. A growing number of scholars have questioned the appropriateness of using HHIs when products are differentiated. See Jerry A. Hausman \& Gregory K. Leonard, Economic Analysis of Differentiated Products Mergers Using Real World Data, 5 GEO. MASON L. REV. 321, $337-38$ (1997); Thomas Overstreet et al., Understanding Econometric Analysis of the Price Effects of Mergers Involving Differentiated Products, ANTITRUST, Summer 1996, at 30-31; Gregory J. Werden, Simulating the Effects of Differentiated Products Mergers: A Practical Alternative to Structural Merger Policy, 5 GEO. MASON L. REV. 363, 368-69 (1997); Gregory J. Werden \& Luke M. Froeb, The Effects of Mergers in Differentiated Products Industries: Logit Demand and Merger Policy, 10 J.L. ECON. \& ORG. 407, 423-24 (1994). It should be noted that such concerns were raised in the context of horizontal rather than vertical integration. In addition, although senior Justice Department officials acknowledge these problems, they still continue to advocate the use of HHIs. See Carl Shapiro, Mergers with Differentiated Products, ANTITRUST, Spring 1996, at 23, 28-29.

160 The FCC has traditionally taken a conservative approach to attribution, tending to regard equity positions as low as five percent as constituting an attributable interest. 47 C.F.R. $\$ \S 21.912$ note 1(a), 73.3555 note 2(a), 76.501 note 2(a) (2000). The problem is that, while this approach may be appropriately conservative in the context in which it has been applied, when calculating HHIs, taking a broad approach to attribution may understate the degree of industry concentration. This is because allowing control of a particular group of viewers to be counted as part of the audience of more than one network tends to double count viewers in ways that makes market shares appear artificially low. For general commentary on the problems associated with partial integration, see Timothy F. Bresnahan \& Steven C. Salop, Quantifying the Competitive Effects of Production Joint Ventures, 4 INT'L J. INDUS. ORG. 155 (1986); Daniel P. O'Brien \& Steven C. Salop, Competitive Effects of Partial Ownership: Financial Interest and Corporate Control, 67 ANTITRUST L.J. 559, $594-98$ (2000); and Janusz A. Ordover \& Carl Shapiro, The General Motors-Toyota Joint Venture: An Economic Assessment, 31 WAYNE L. REV. 1167, $1189-94$ (1985). 
Vertical Integration and Media Regulation in the New Economy

Table II. Concentration of the Market for Television Networks by Audience Share as of November 2000

\begin{tabular}{lrrr}
\hline Network Owner & Rating & Share & HHI \\
\hline Viacom, Inc. & 16.6 & $23 \%$ & 550 \\
Walt Disney Co. & 16.3 & $23 \%$ & 530 \\
News Corp. & 9.9 & $14 \%$ & 196 \\
General Electric Co. & 9.8 & $14 \%$ & 192 \\
AOL Time Warner Inc. & 8.2 & $12 \%$ & 134 \\
Liberty Media Corp. & 4.8 & $7 \%$ & 46 \\
USA Networks, Inc. & 2.7 & $4 \%$ & 15 \\
Other & 2.5 & $4 \%$ & 4 \\
& & & \\
Total & 70.2 & $100 \%$ & 1667 \\
\hline
\end{tabular}

Source: Appendix A.

Table III. Concentration of the Market for Television Networks by Dollar Share as of 2000

\begin{tabular}{lccc}
\hline Network Owner & $\begin{array}{l}\text { Revenue } \\
\text { (\$ in billions) }\end{array}$ & Share & HHI \\
\hline Walt Disney Co. & 8.1 & $24 \%$ & 565 \\
Viacom, Inc. & 6.1 & $18 \%$ & 316 \\
General Electric Co. & 5.2 & $15 \%$ & 233 \\
AOL-Time Warner Inc. & 4.9 & $14 \%$ & 207 \\
Liberty Media Corp. & 4.7 & $14 \%$ & 188 \\
News Corp. & 2.4 & $7 \%$ & 49 \\
USA Networks, Inc. & 2.3 & $7 \%$ & 45 \\
Other & 0.5 & $1 \%$ & 2 \\
& & & \\
Total & 34.2 & $100 \%$ & 1605 \\
\hline
\end{tabular}

Source: Appendix B.

The FCC has drawn the same conclusion in its recent regulatory decisions. For example, in eliminating the term of affiliation rule in 1988, the FCC concluded that the emergence of new broadcast stations, as well as the emergence of cable television, substantially mitigated the possibility that a broadcast network would be able to use its market position to harm 
competition. ${ }^{161}$ Similarly, in its 1995 action to eliminate the Prime Time Access Rule, the FCC concluded that the increase in the number of broadcast television networks had so deconcentrated the market that it was no longer necessary to protect local television affiliates against possible dominance by the broadcast networks. ${ }^{162}$ As a result, the FCC concluded that the market for broadcast television networks was too unconcentrated to permit any network to dominate the market for video programming distribution. ${ }^{163}$ The subsequent emergence of DBS and other alternative sources of video programming will only further erode the position of the broadcast networks.

\section{Concentration and Barriers to Entry in the Market for Home Delivery of Television Programming}

In order for vertical integration to harm competition, the Vertical Merger Guidelines require more than just concentration in the primary market; the secondary market must also be susceptible to monopolization. There is reason to doubt that the market for local broadcast stations is sufficiently concentrated to raise this type of risk. The FCC's Network Inquiry Staff concluded in 1980 that the market for broadcast television stations was sufficiently unconcentrated as to render any attempt at foreclosure unprofitable. ${ }^{164}$ At the time, the average U.S. household could receive 3.9 over-the-air television stations. ${ }^{165}$ By the year 2000 , the number of stations received by the average household had increased to thirteen, a more than threefold increase over the number found unconcentrated twenty years earlier. ${ }^{166}$ Furthermore, since that time technological change has deconcentrated the market and lowered the

161 Review of Rules and Policies Concerning Network Broad. by Television Stations: Elimination or Modification of Section 73.658(c) of the Comm'n's Rules, 4 F.C.C.R. 2755, 2757, 19 14-16 (1989) (Report and Order).

162 Review of the Prime Time Access Rule, 11 F.C.C.R. 546, 562 n.64 (1995) (Report and Order) (noting that the $\mathrm{HHI}$ for national prime-time broadcast television program distribution was 1366).

163 Id. at 556, 120 . The FCC drew a similar conclusion in the proceedings that led to the repeal of the financial interest and syndication rules ("finsyn"). See Review of the Syndication and Fin. Interest Rules, Sections 73.659-73.663 of the Comm'n's Rules, 10 F.C.C.R. 12,165, 12,170, ๆf 26-27 (1995) (Report and Order); Evaluation of the Syndication and Fin. Interest Rules, 8 F.C.C.R. 3282, 3296, ๆๆ 43-50 (1993) (Second Report and Order); Amendment of 47 C.F.R. $\S 73.658(j)(1)(i)$ and (ii), Syndication and Fin. Interest Rules, 94 F.C.C.2d 1019, 1052, ๆ 124-25 (1983) (Tentative Decision and Request for Further Comments).

164 MisREgulating TELEVISION, supra note 32, at 60, 72-73, 169.

165 Review of Rules and Polices Concerning Network Broad. by Television Stations: Elimination or Modification of Section 73.658(c) of the Comm'n's Rules, 3 F.C.C.R. 5681, 5685, If 17 (1988) (Notice of Proposed Rulemaking).

166 See 1998 Biennial Regulatory Review-Review of the Comm'n's Broad. Ownership Rules and Other Rules Adopted Pursuant to Section 202 of the Telecomms. Act of 1996, 15 F.C.C.R. 11,058, 11,064, II 9 (2000) (Biennial Review Report). 


\section{Vertical Integration and Media Regulation in the New Economy}

barriers to entry still further. As noted earlier, cable television and other forms of multichannel video programming distribution have emerged as real alternatives to broadcasting and have captured eighty-six percent of all U.S. households.

Any remaining doubts are likely to be shattered by the imminent arrival of digital television, which is scheduled to completely supplant the current regime of analog transmission by the end of 2006. ${ }^{167}$ Although early analyses assumed that digital broadcasters would transmit a single channel of high definition television, it is now clear that a digital television station also has the option to broadcast up to six standard definition digital channels in the same amount of spectrum. ${ }^{168}$ The prospect of the average household being able to receive more than seventy over-the-air broadcast channels seems to all but guarantee that the local video distribution markets will continue to be too unconcentrated for any degree of vertical integration between a television network and its broadcast affiliates to harm competition.

\section{Potential Efficiency Justifications}

The final step in the economic analysis of vertical integration in the broadcast television industry is an evaluation of possible efficiency justifications that would justify permitting such integration to occur. An analysis of the cost structure associated with producing and transmitting television programming reveals that it is quite possible that broadcast television networks will be able to realize significant economies from vertical integration. As the following section will discuss in detail, the combination of large, up-front fixed costs associated with creating the first copy of television programs and minimal costs associated with distributing

16747 U.S.C. $\$ 309(j)(14)(A)(200 l)$. The statute extends this date if fewer than eighty-five percent of the station's viewers can receive the broadcaster's digital signal either off-air or through satellite or cable television. 47 U.S.C. $\S 309(j)(14)(B)(2001)$. There are those that doubt whether sufficient digital televisions will be sold to meet this standard.

168 As the FCC has noted:

In addition to being able to broadcast one, and under some circumstances two, high definition television ("HDTV") programs, the [digital television] Standard allows for multiple streams, or "multicasting," of Standard Definition Television ("SDTV") programming at a visual quality better than the current analog signal. Utilizing this Standard, broadcasters can transmit three, four, five, or more such programs streams simultaneously.

Advanced Television Syss. and their Impact Upon the Existing Television Broad. Serv., 11 F.C.C.R. 17,771, 17,772, I 5 (1996) (Fourth Report and Order), modified, 12 F.C.C.R. 3388 (1997) (Order); accord Thomas W. Hazlett, Digitizing "Must-Carry" Under Turner Broadcasting v. FCC (1997), 8 SUP. CT. ECON. REV. 141, 145 (2000) ("TV licensees have the option of either broadcasting a high definition TV (HDTV) signal or multiplexing channel broadcasts to produce multiple digital standarddefinition television (SDTV) signals, which could accommodate four to six SDTV sub-channels or more.") (citing CONGRESSIONAL Budget OfFICE, COMPLETING THE TRANSITION TO DIGITAL TELEVISION (1999)). 
programs to additional viewers give television programming many of the attributes of a pure public good. ${ }^{169}$ The existence of high initial fixed costs leaves broadcast networks quite vulnerable to opportunistic behavior. Broadcast networks can eliminate these problems by using vertical integration to guarantee that they will have access to audiences for their programs. In addition, television programming has other qualities that increase the transaction costs associated with program distribution still further. The existence of these features makes it quite possible that vertical integration will yield benefits sufficient to justify releasing the industry from the strictures of the Chain Broadcasting Rules.

\section{a. Elimination of Double Marginalization and Static Transaction Costs}

The most singular economic feature of the broadcast industry is its unique cost structure. Specifically, the creation of television programming requires the incurrence of large, up-front, first-copy costs, while the cost of making and distributing additional copies is trivial in comparison. Since marginal costs are close to zero, vertical integration can allow firms to mitigate the problems of double marginalization by charging a more economically efficient transfer price. In addition, this cost structure causes average cost to decline over all relevant volumes, as the large up-front investments are amortized over an increasingly large number of viewers. When faced with such a declining cost structure, economic efficiency increases with every additional viewer reached. Broadcast programming thus exhibits a natural tendency to seek as broad an audience as possible. This does not mean that all programs must secure universal distribution in order to survive or even that those programs that do achieve nationwide distribution must achieve dominant shares. On the contrary, the economic evidence suggests that programming is not a natural monopoly and that the minimum viable scale for broadcast programming is relatively small when compared to the nationwide audience. What it does mean is that broadcast programming will naturally exhibit a tendency towards an equilibrium level of distrubtion that is fairly widescale. ${ }^{170}$ The logical way for a network to secure such access would be for it to vertically integrate into the downstream stage or to negotiate contracts with its broadcast affiliates guaranteeing it the ability to reach a large enough audience to lower its costs. It also means that artificial barriers that prevent programming from

169 BRUCE M. OWEN \& STEVEN S. WILDMAN, VIDEO ECONOMICS 23-24 (1992).

170 NEW TELEVISION NeTWORKS, supra note 28, at 398 \& n.185, 519; MisReGUlatiNG TELEVISION, supra note 32, at 5; Thomas G. Krattenmaker \& A. Richard Metzger, Jr., FCC Regulatory Authority over Commercial Television Networks: The Role of Ancillary Jurisdiction, 77 NW. U. L. REV. 403, 408 (1982). 
securing its natural level of distribution can cause investment in programming to fall below efficient levels. The Chain Broadcasting Rules represent a significant obstacle to networks seeking to guarantee access to viewers.

\section{b. Elimination of Strategic Behavior}

In addition, the broadcast market is susceptible to all three types of opportunistic behavior identified above. Specifically, the existence of large, up-front fixed costs leaves networks vulnerable to the problems associated with hold up and free riding. In addition, the fact that the popularity of a particular television program is notoriously hard to determine ex ante leaves networks vulnerable to adverse selection. Unfortunately, the Chain Broadcasting Rules prevent networks from using vertical integration or a related vertical contractual restraint to minimize or even eliminate these problems.

Hold Up. The sunk cost investment needed to create original television programming exposes broadcast networks to the possibility of being held up. Networks, of course, will not invest in programming unless it is likely that they will be able to recover both the fixed costs associated with creating the programming, as well as the marginal costs of distribution. Once the first-copy costs are sunk, however, it is possible for broadcast stations to hold out in an attempt to avoid having to contribute to fixed costs. The classic way to deter hold up behavior is either to vertically integrate into retail distribution or to enter into a long-term contract or some other contractual device that brings the interests of both parties into alignment. Unfortunately, this is precisely the type of contract barred by the Chain Broadcasting Rules.

Free Riding. The network-affiliate relationship is also potentially fraught with free rider problems. Recall that the value of a program is determined in no small part by the network's ability to reach the largest audience possible. Network profitability thus depends upon the willingness of affiliates to "clear" programs provided by the network, since doing so allows the first-copy costs to be spread across the largest possible audience. Because of this, the value of the network to the local broadcast affiliates depends upon the behavior of other affiliates, since the refusal by any affiliate to carry a program offered by the network causes the fixed costs to be spread over a smaller number of viewers. So long as this danger exists, networks will factor the risk of non-carriage into their initial decision to invest in programming. As the networks' willingness to invest in programming decreases, so does the profitability of the local broadcast station. In other words, each affiliate's programming decisions can impose significant negative externalities on other affiliates, as greater defections 
lead to inefficient program distribution and lower overall investments in programming.

The ideal situation for a network affiliate, however, is to refuse to carry the least profitable programming provided by the network and to contribute as little as possible to the fixed costs associated with creating the programming. In effect, a station has the incentive to attempt to free ride on the willingness of other affiliates to bear the costs associated with creating and maintaining the network. Since all of the affiliates have the same incentives in this regard, absent coordination sufficient to solve this collective action problem, the affiliates will defect at an inefficiently high rate. This will lead to an inefficient level of program distribution, which will in turn create inefficiently low levels of investment in programming.

All of this could be solved by allowing networks to protect against such free riding either by vertically integrating into the retail distribution stage or by entering into affiliation agreements that limit an affiliate's ability to refuse to carry network programming. Doing so would not only create a sounder financial basis for investment in the abstract, it would also decrease the likelihood that an affiliate could free ride on fellow affiliates. ${ }^{171}$ Again, the Chain Broadcasting Rules effectively prevent television networks from availing themselves of either option.

Adverse Selection. Another feature of the network-affiliate relationships is the potential for adverse selection. As discussed earlier, adverse selection arises when the quality of a product varies and is hard to determine in advance. Customers looking to purchase such products have the incentive to search to find the highest quality goods. The customer who succeeds in finding such goods receives a windfall, having received goods of above average quality without having to pay more than the average price. In addition, the seller will be left with an inventory of below average goods that it will be unable to sell at the average price. The need to avoid this will lead to oversearching, as sellers invest additional resources in presorting the goods and pricing them at different points and buyers invest additional resources inspecting the goods in an attempt to gain an information advantage over each other.

Television programming bears all of the characteristics of a classic adverse selection problem. As noted earlier, the quality of goods varies and is very hard to determine ex ante when the initial investment in creating the program is made. ${ }^{172}$ The networks could avoid adverse selection problems either by vertically integrating, by entering into an exclusive dealing arrangement, ${ }^{173}$ or by bundling programs together in a

171 OWEN \& WILDMAN, supra note 169, at 171-72.

172 See id. at 164; see also Kenney \& Klein, supra note 100, at 534 (noting that the value of movies can be hard to determine in advance).

173 See OWEN \& WILDMAN, supra note 169 , at 163 
way that forces the local broadcast affiliates to focus on the average quality of the programs. ${ }^{174}$ Unfortunately, the existing prohibitions on option time and mandatory clearance included in the Chain Broadcasting Rules prevent networks from fully mitigating these problems in this manner.

There are thus several plausible arguments that permitting vertical integration in the broadcast industry would allow firms to realize efficiencies. As noted earlier, for the purposes of my argument, it is not necessary to establish that such efficiencies actually exist in all cases with respect to broadcasting. The key question underlying the choice between a per se and a rule of reason approach is whether such efficiencies are so implausible and the practice in question so inherently suspect that little would be served by evaluating whether any such efficiencies actually exist in a particular case. It thus suffices to conclude that the danger of anticompetitive effects seems so remote and the potential efficiencies seem sufficiently plausible to justify rejecting flat regulatory prohibition of vertical integration in the broadcasting industry.

\section{The Future of the Chain Broadcasting Rules}

The foregoing analysis reveals that the market for broadcast networks and the market for broadcast stations are both sufficiently unconcentrated and unprotected by barriers to entry as to make it unlikely that any television network could use vertical integration in a way that could harm competition. Furthermore, it appears that vertical integration could yield significant efficiency benefits. The problem, as one group of distinguished commentators has noted, is that the "the network-affiliate relationship is overregulated" and that the FCC's focus on the supposed exclusionary danger of the practices of the broadcast networks "has been so singleminded as to induce a form of regulatory paranoia."175 These commentators argued that the Chain Broadcasting Rules should therefore be abolished.

The FCC agreed up to a point. For example, in 1989, the FCC eliminated the rule limiting the term of network affiliation agreements to two years. ${ }^{176}$ The FCC concluded that increases in the number of independent television stations and the emergence of cable television rendered it extremely unlikely that the use of long-term contracts posed a

174 Cf. NEW TELEVISION NETWORKS, supra note 28, at 240-41; Kenney \& Klein, supra note 100 , at 505 .

175 MiSREgUlating TeleVISION, supra note 32, at 92.

176 Review of Rules and Policies Conceming Network Broad. by Television Stations: Elimination or Modification of Section 73.658(c) of the Comm'n's Rules, 4 F.C.C.R. 2755 (1989) (Report and Order). 
significant threat to competition. ${ }^{177}$ The FCC further concluded that, by limiting the networks' ability to obtain guaranteed access to programming outlets, the rule was discouraging the networks from investing in television programming. ${ }^{178}$ Moreover, since the program production and acquisition cycle often exceeded two years, the rule left the networks in the position of having to invest in programming without any ability to control or predict the size and location of the audience that would eventually be able to see the program. ${ }^{179}$ The reduction in uncertainty would likely be especially beneficial to new networks, which confront significantly higher risks than established networks. Ironically, the FCC concluded, the term of affiliation rule "'may actually have the perverse effect of impeding new network entry, without providing any countervailing benefits."

In 1995, the FCC also eliminated the provision of the Chain Broadcasting Rules that prohibited networks from owning stations in small communities. ${ }^{181}$ The FCC concluded that the increase in competition for television from new networks and the emergence of cable and DBS rendered it unlikely that any such vertical integration would harm competition. ${ }^{182}$ On the contrary, vertical integration offered networks the chance to take advantage of managerial, technical, and other efficiencies that would improve the financial viability and competitiveness of television broadcast stations in small markets. ${ }^{183}$

The drive to repeal the Chain Broadcasting Rules eventually stalled, however, as a proceeding to repeal the remaining provisions of the Chain Broadcasting Rules has remained open without action since $1995 .{ }^{184}$ As a result, the rules prohibiting exclusive affiliation agreements, territorial exclusivity, compulsory carriage, and option time remain in force today: ${ }^{185}$ Therefore, despite the fact that the structure of the relevant markets is such that additional degrees of vertical integration would pose little threat to competition, broadcast networks remain unable to take certain steps that might allow them to realize all of the available efficiencies. Thus, the continued existence of these rules not only reflects an incomplete understanding of the economics of vertical integration, it also harms consumers by reducing the quality of programming available on broadcast television. It remains to be seen whether the accession of a new FCC

177 Id. at 2757 , ๆ $14-16$.

178 Id. at $2757, \Upsilon 17$.

179 Id. at $2757, \mathbb{1} 18$.

180 Id. at 2757, 17 (quoting NEW TELEVISION NETwORKS, supra note 28, at 486).

181 Review of the Comm'n's Regulations Goveming Television Broad., 10 F.C.C.R. 4538 (1995) (Report and Order).

182 Id. at $4539-40$, शा 8,10

183 Id. at $4540, \$ 11$.

184 See Review of the Comm'n's Regulations Governing Programming Practices of Broad Television Networks and Affiliates, 10 F.C.C.R. 11,951 (1995) (Notice of Proposed Rulemaking).

18547 C.F.R. $\$ 73.658(2001)$. 
Chairman will spark new interest in bringing this proceeding to completion.

Recent events have also placed renewed focus on the other set of regulations primarily responsible for blocking vertical integration by the broadcast networks. The FCC recently denied the broadcast networks' request that it repeal the rule prohibiting persons from owning stations capable of reaching more than thirty-five percent of the nationwide audience. ${ }^{186}$ The FCC agreed to refrain from enforcing that rule until a pending judicial challenge to that decision was completed. ${ }^{187}$ In the meantime, the issue created a major schism within the National Association of Broadcasters, as both NBC and Fox have withdrawn to protest the Association's refusal to support lifting the thirty-five percent national audience cap. ${ }^{188}$ As this Article was going to press, the D.C. Circuit struck down the national audience cap as arbitrary and capricious as well as a violation of the FCC's statutory mandate. ${ }^{189}$ Given the salience of this issue, it is quite possible that proceedings in connection with the national ownership caps will provide policy makers with an opportunity to rethink their approach to regulating vertical integration in the broadcast industry.

\section{The 1992 Cable Act and the Dynamic Inefficiency of Compelled Access}

Anyone who peruses the findings and the legislative history of the 1992 Cable Act will easily discern that its enactment was animated in no small part by concern over the increase in vertical integration in the cable industry that was taking place at that time. ${ }^{190}$ Some of its provisions imposed ownership restrictions similar to those appearing in the regulatory

1861998 Biennial Regulatory Review-Review of the Comm'n's Broad. Ownership Rules and Other Rules Adopted Pursuant to Section 202 of the Telecomms. Act of 1996, 15 F.C.C.R. 11,058, $11,072-74$, शT 25-30 (2000) (Biennial Review Report)

187 See UTV of San Francisco, Inc., 16 F.C.C.R. 14,975, 14,982, ๆ 25 (2001). The FCC's action followed an initial refusal to suspend the national ownership restrictions for broadcasting in the wake of the D.C. Circuit's decision in Time Warner Entertainment Co. v. FCC, 240 F.3d 1126 (D.C. Cir.), cert. denied, 122 S. Ct. 644 (2001), which overtumed a similar national ownership restriction for cable. See Applications of Shareholders of CBS Corp., 16 F.C.C.R. 5831 (2001).

188 Paige Albiniak, Fox Bows Out of NAB, BROAD. \& CABLE, June 14, 1999, at 15; Paige Albiniak, Peacock Finally Flies NAB, BROAD. \& CABLE, Mar. 13, 2000, at 20.

189 See Fox Television Stations, Inc. v. FCC, Nos. 00-1222 et al., 2002 WL 233650, at *10*16 (D.C. Cir. Feb. 19, 2002).

190 See Cable Television Consumer Protection and Competition Act of 1992, Pub. L. No. 102-385, $\$ 2(a)(5), 106$ Stat. $1460,1460-61$ (entering legislative findings about the harms associated with vertical integration in the cable industry); id. $\S 2(\mathrm{~b})(5), 106$ Stat. at 1463 (stating that it is the policy of Congress to "ensure that cable television operators do not have undue market power vis-à-vis video programmers and consumers"); S. REP. NO. 102-92, at 23-32 (1992), reprinted in 1992 U.S.C.C.A.N. 1133, 1156-65 (reviewing the problems caused by vertical integration in the cable industry). 
regime governing broadcasting. Most distinctive about the approach taken by the 1992 Cable Act was its greater emphasis on a different regulatory device-compelled access requirements - to redress the problems of vertical integration. ${ }^{191}$

This Part will evaluate the policy underlying the restrictions on vertical integration contained in the 1992 Cable Act by assessing the extent to which vertical integration in the cable industry poses a sufficient threat to competition. Section A will describe the basic structure of the cable television industry and the regulatory scheme erected by the 1992 Cable Act. Section B will apply the basic economic approach developed in Part I to the cable television industry in order to assess the extent to which vertical integration in the cable industry poses a real threat to competition. Section $\mathrm{C}$ will examine the unique problems posed by access as a remedy to the problems of vertical integration. A review of the academic literature reveals that compelled access is quite problematic as a remedy to vertical integration. Section $\mathrm{D}$ will review the prospects for changes to the existing regulatory regime.

\section{A. Description of the Cable Industry and the Regulatory Restrictions on Vertical Integration}

\section{The Structure of the Cable Industry}

Just like broadcasting, the cable industry can be mapped onto the basic three-stage chain of production comprised of manufacturers, wholesalers, and retailers that typifies the distribution of many, if not most, physical goods in the U.S. economy. ${ }^{192}$ As was the case in broadcasting, the manufacturing stage is again occupied by the movie studios and others

191 Although broadcast regulation did include some access requirements, those were restricted to political speech and were motivated primarily by the desire to promote free speech and to improve the functioning of the political process. See 47 U.S.C. $\S \S 312(a)(7), 315$ (1994); see also Red Lion Broad. Co. v. FCC, 395 U.S. 367 (1969) (describing the now defunct Faimess Doctrine, Political Editorial Rule, and Personal Attack Rule). Competition policy in general, and vertical integration in particular, did not appear to be a motivation behind the access requirements imposed on broadcasters.

192 LEVY \& SETZER, supra note 148, at 39-40; see Lawrence J. White, Antitrust and Video Markets: The Merger of Showtime and the Movie Channel as a Case Study, in VIDEO MEDIA COMPETITION: REgULATION, ECONOMICS, AND TECHNOLOGY 338, 347-48 (Eli M. Noam ed., 1985). It is more natural to conceive of the relationship between the wholesale and retail stages of the cable industry as a purely vertical relationship than it is with respect to broadcasting, in which the wholesale and retail stages are also horizontal competitors for advertising dollars. See supra note 27 and accompanying text. This is because, unlike in broadcasting, viewers are able to signal the intensity of their preferences through direct payments. As a result, advertising represents a nearly inconsequential amount of the revenue at the retail stage of the chain of production. See Michael G. Vita \& John P. Wiegand, Must-Carry Regulations for Cable Television Systems: An Economic Policy Analysis, $37 \mathrm{~J}$. BROAD. \& ELEC. MEDIA 1 (1993) (reporting that advertising represents on average only $1.8 \%$ of a cable operator's total revenue). 
who create original television programming, as well as syndicators and others who hold the rights to programming that has already been produced. The wholesale stage is represented by the cable networks (such as Lifetime, TBS, the USA Network, Nickelodeon, A\&E, and the Discovery Channel), which acquire the right to air programs and aggregate them into program packages. Integration between the manufacturing and wholesale stage is quite common in cable, with such popular networks such as CNN and ESPN airing high percentages of programming that they produce themselves. Because these functions are not as distinct as they generally are in broadcasting, producers of original programming and cable networks are often collectively referred to as "cable programmers."193

The retail stage of the cable industry consists of local "cable operators," who receive licenses from municipal governments to operate the web of coaxial cables connecting individual homes and for transmitting the television programming into those homes. ${ }^{194}$ A company that controls cable operators in more than one city is called a "multiple system operator" ("MSO"). The largest MSOs in the U.S. include AT\&T Broadband, Time Warner Cable, Comcast Cable Communications, Charter Communications, Cox Communications, and Adelphia Communications. ${ }^{195}$

Historically, many of the largest MSOs have vertically integrated into cable programming. For example, the second-largest MSO, AOL-Time Warner, also controls a number of major cable networks, including TBS, CNN, TNT, the Cartoon Network, HBO, and Cinemax. The third-largest MSO, Comcast Communications, also runs a family of cable networks that includes QVC, E!, and the Golf Channel. The largest MSO in the U.S., AT\&T Broadband, similarly held major equity positions in a number of cable networks until it completed its spin-off of Liberty Media on August 10, 2001. Cable networks that are under the same corporate umbrella as a particular cable operator are called "affiliated programmers." Cable networks with which a cable operator has no vertical relationship are called "unaffiliated programmers."

\section{Provisions of the 1992 Cable Act Affecting Vertical Integration}

The 1992 Cable Act contained a variety of measures designed to curb the supposed dangers posed by vertical integration in the cable industry. Many of these took the now familiar form of ownership limits and structural restrictions. For example, Congress enacted the so-called

193 See Turner Broad. Sys., Inc. v. FCC, 512 U.S. 622, 628 (1994).

194 Id.

195 See National Cable \& Telecommunications Association, Top 25 MSOs (June 30, 2001), at http://www.ncta.com/industry_overview/top50mso.cfm. 
"channel occupancy" provision, which authorized the FCC to place limits on the number of channels that cable operators could devote to networks with which they are vertically affiliated. ${ }^{196}$ Initially, the FCC set this limit at forty percent of the operator's channel capacity, only to see that limit invalidated by the courts. ${ }^{197}$

The 1992 Cable Act also includes the so-called "subscriber limit" provision, which authorizes the FCC to cap the number of cable subscribers that any MSO can reach nationwide. ${ }^{198}$ To implement this provision, the FCC initially prohibited any MSO from servicing more than thirty percent of all MVPD subscribers only to see those limits invalidated as well. ${ }^{199}$ At first blush, this limit appears horizontal in focus. On closer inspection, however, it becomes clear that that is not the case. Horizontal integration involves a merger of direct competitors. Cable operators in different cities, however, serve different geographic markets and as a result do not compete with one another. ${ }^{200}$ Thus, a merger between cable operators serving different cities is not properly regarded as a true horizontal merger, since such a merger cannot be said to eliminate any direct competition. The real purpose for the subscriber limits is to prevent large MSOs from exerting too much bargaining power upstream against cable programmers in the national market for television programming. ${ }^{201}$ Thus, the subscriber limits are more properly understood as being driven by vertical, rather than horizontal, concerns and as focusing on the national market in which MSOs contract with cable programmers, rather than the local markets in which cable operators contract with end users. In addition, even when vertical integration was permitted, the Act prohibits vertically integrated operators from entering into exclusive dealing contracts. ${ }^{202}$

19647 U.S.C. $\$ 533(\mathrm{f})(1)(\mathrm{B})(1994)$.

197 Implementation of Sections 12 and 19 of the Cable Television Consumer Protection Act of 1992, 8 F.C.C.R. 8565, 8592-96, ๆT 64-70 (1993) (Second Report and Order), rev'd \& remanded sub nom. Time Warner Entm't Co. v. FCC, 240 F.3d 1126, $1137-39$ (D.C. Cir.), cert denied, 122 S. Ct. 644 (2001). The channel occupancy limit promulgated by the FCC applied only to the first seventyfive channels of any cable operator's capacity. Any additional channel capacity was not subject to the limit. Id. at 8601-02, $\pi 84$.

$198 \quad 47$ U.S.C. § 533(f)(1)(A) (1994).

199 Implementation of Section 11(c) of the Cable Television Consumer Protection Act of 1992, 14 F.C.C.R. 19,119, $\{55$ (1999). Subscribers to new cable systems and cable systems in direct competition with other cable systems did not count against the thirty percent cap. Id. at 19,112-13, IT 33-34, 37 .

200 See Thomas G. Krattenmaker, The Telecommunications Act of 1996, 29 CONN. L. REV. 123, 168 (1996) (noting that broadcasters and cable operators in Chicago do not discipline broadcasters and cable operators in New York in the market for selling television to viewers).

201 See Time Warner Entm't, 211 F.3d at 1319 (noting that Congress enacted the subscriber limits in part because of the concern that "a few dominant cable operators might preclude new programming services from attaining the critical mass audience necessary to survive"); see also 14 F.C.C.R. at $19,116, \uparrow 43$.

202 The statute prohibits exclusive dealing contracts in all areas served by cable at the time the 1992 Cable Act was passed unless the FCC determines that such contract is in the public interest. 
The most striking feature of the 1992 Cable Act is the inclusion of several compelled access requirements. The most controversial of these were the "must-carry" provisions, which required cable operators to provide free carriage to all full-power stations broadcasting within the operator's service area. ${ }^{203}$ In addition, the "leased access" provision requires all cable systems with more than thirty-five channels to set aside part of their channel capacity for use by unaffiliated programmers. ${ }^{204}$ Finally, the "program access" provisions prohibit vertically integrated programmers from refusing to deal with unaffiliated operators and from discriminating against them in the terms and conditions of providing programming. ${ }^{205}$

\section{The Economic Theory Underlying the Restrictions on Vertical Integration Contained in the 1992 Cable Act}

A close analysis of the rationales underlying these provisions reveals that, in enacting them, Congress was motivated by the same type of economic concerns that lay behind the enactment of the Chain Broadcasting Rules. The first was the concern that vertically integrated programmers would use the leverage provided by their monopoly position in the retail stage to discriminate against unaffiliated cable programmers, thereby reducing competition in the wholesale stage of production. ${ }^{206}$ For example, there is anecdotal evidence that Time Warner was able to

47 U.S.C. $\S 548$ (c)(2)(D), (c)(4) (1994). In all other areas, exclusive dealing contracts are absolutely barred. Id. $\S 548(\mathrm{c})(2)(\mathrm{C})$.

$203 I d . \S \S 534,535$. The must-carry provisions of the 1992 Cable Act followed two unsuccessful attempts to impose must-carry by the FCC. See Century Communications Corp. v. FCC, 835 F.2d 292 (D.C. Cir. 1987), cert. denied, 486 U.S. 1032 (1988); Quincy Cable TV, Inc. v. FCC, 768 F.2d 1434 (D.C. Cir. 1985), cert. denied, 476 U.S. 1169 (1986).

204 The amount of channel capacity that must be set aside for leased access varies from ten to fifteen percent, depending on the size of the cable operator. 47 U.S.C. $\$ 532$ (b)(1) (1994). This statute in effect overtumed a previous Supreme Court decision holding that the FCC lacked the authority to mandate leased access. See FCC v. Midwest Video Corp., 440 U.S. 689 (1979). Leased access was originally enacted in 1984 in order to bring about the First Amendment-related concern of assuring the availability of "the widest possible diversity of information sources" for cable subscribers. 47 U.S.C. $\S 532(a)$. The 1992 Cable Act added a second rationale for leased access that focused on competition. See id. (adding that leased access was intended "to promote competition in the delivery of diverse sources of video programming").

20547 U.S.C. $\$ 548$ (c)(2)(B) (1994). Regulators imposed similar conditions while approving both the Time Warner-Tumer Broadcasting and the Liberty-TCl mergers. See United States v. TeleCommunications, Inc., No. 94-0948, 1994 WL 904122 (D.D.C. Aug. 19, 1994); Time Wamer, Inc., 123 F.T.C. 171 (1997).

206 See Cable Television Protection and Competition Act of 1992, Pub. L. No. 102-385, $\S 2$ (a)(5), 106 Stat. 1460, 1460-61 (finding that vertical integration gives vertically integrated programmers "the incentive and ability to favor their affiliated programmers" and "could make it more difficult for noncable-affiliated programmers to secure carriage on cable systems"); S. REP. NO. 10292, at 25 (1992), reprinted in 1992 U.S.C.C.A.N. 1133, 1158 (noting the concern that "vertical integration gives cable operators the incentive and ability to favor their affiliated programming services"). 
forestall NBC's first attempt to set up a cable news network to compete directly with CNN simply by having all of the local cable operators under its control refuse to carry the new network. Time Warner's cable operators only agreed to carry what would become CNBC after NBC agreed to focus solely on business news and not to take steps to become a general news service. ${ }^{207}$ Since this concern focuses on the possibility that a company could use market power in one market to attack another market, this argument corresponds to the concerns about leverage that underlay the Chain Broadcasting Rules.

The second was the danger that vertically affiliated programmers would lock up key cable programmers in order to suppress the emergence of new MVPDs that would weaken their monopoly at the retail level. The theory is that vertically integrated programmers could create barriers to entry to DBS systems and other potential MVPD entrants by denying them access to key cable networks. ${ }^{208}$ For example, the fear is that AOL-Time Warner could forestall the emergence of DBS as a competitor to its local cable operations by refusing to allow DBS to carry CNN, TBS, HBO, or any of the other cable networks that it controls. This concern is analogous to the foreclosure rationale underlying the Chain Broadcasting Rules.

In rejecting a First Amendment challenge to the must carry provisions in Turner Broadcasting System, Inc. v. FCC ("Turner II"), ${ }^{209}$ a plurality of the Supreme Court implicitly condoned the approach to vertical integration taken by the 1992 Cable Act. The Court concluded that Congress had before it substantial evidence that cable operators had ample incentive to drop local broadcasters in favor of affiliated programmers. ${ }^{210}$ The plurality stopped short of putting its imprimatur on any particular economic theory of vertical integration embodied in the regulations, opting instead to defer to the judgment of Congress so long as that judgment was backed by substantial evidence. ${ }^{211}$

207 See WATERMAN \& WEISS, supra note 21, at 55-56 (citing Competition, Rate Deregulation and the Comm'n's Policies Relating to the Provision of Cable Television Serv., 5 F.C.C.R. 4962, 5028-29, ๆ 120-22 (1990) (Report) [hereinafter 1990 Report on Cable Competition]).

208 See $\S 2(a)(5), 106$ Stat. at 1461 (finding that "[v]ertically integrated program suppliers ... have the incentive and ability to favor their affiliated cable operators over . . . programming distributors using other technologies"); S. REP. NO. 102-92, at 26 (1992), reprinted in 1992 U.S.C.C.A.N. 1133,1159 (noting the concern that vertically integrated cable programmers had the incentive and the ability to forestall entry by alternative video distribution technologies by discriminating on the price and terms of providing programs or by simply refusing to sell any programming).

209520 U.S. 180, 196-200 (1997) (plurality opinion). Justice Breyer declined to join this portion of Justice Kennedy's opinion, basing his decision solely on the government's asserted interest in "(1) preserving the benefits of free, over-the-air local broadcast television and (2) promoting the widespread dissemination of information from a multiplicity of sources." Id. at 226 (Breyer, J., concurring in part) (internal quotation marks omitted).

210 Id. at 197-98 (plurality opinion). Additional evidence submitted in the district court bolstered this conclusion. See id. at 200-05.

211 Id. at 208-12. 
The D.C. Circuit initially followed similar reasoning, deferring to Congress's choice of the appropriate economic theory when rejecting facial challenges to the subscriber limits, channel occupancy, and program access provisions. ${ }^{212}$ A recent decision may signal greater skepticism on the part of the D.C. Circuit of the vertical integration theories underlying the 1992 Cable Act. In that decision, the D.C. Circuit struck down the FCC's implementation of the subscriber limits and the channel occupancy provisions on the grounds that the FCC had failed to base its decision upon substantial evidence appearing in the administrative record. ${ }^{213} \mathrm{~A}$ fair reading of the opinion, however, reveals that, in so holding, the D.C. Circuit did not mean to endorse or reject any particular economic theory of vertical integration. In ruling that the FCC had failed to base its decision on substantial evidence, the court specifically reserved the possibility that the FCC could rely on different theories about how vertical integration could harm competition on remand. ${ }^{214}$

It thus appears that the courts and the FCC have yet to settle on any particular economic theory of vertical integration with respect to cable. It is true that the argument that vertical integration does pose a significant threat to competition has considerable intuitive appeal. As one witness who testified regarding the 1992 Cable Act observed, "You don't need a Ph.D. in Economics to figure out that the guy who controls a monopoly conduit is in a unique position to control the flow of programming traffic to the advantage of the program services in which he has an equity investment ... and to the disadvantage of those services ... in which he does not have an equity position." ${ }^{215}$ Application of the analytical framework developed in Part I reveals, however, that, in light of the current structure of the cable industry, such anti-competitive harms, intuitive though they may be, are unlikely to arise. Thus, it seems that, although a Ph.D. in economics may not be necessary to understand the problem, any serious assessment of whether vertical mergers in the cable industry help or harm competition requires more analysis than the testimony quoted above would suggest.

212 See Time Warner Entm't Co. v. FCC, 211 F.3d 1313, 1319-20, 1322 (D.C. Cir. 2000) (subscriber limit and channel occupancy provisions), cert. denied, 531 U.S. 1183 (2001); Time Wamer Entm't Co. v. FCC, 93 F.3d 957, 978-79 (D.C. Cir. 1996) (vertically integrated programmer provisions).

213 Time Warner Entm't Co. v. FCC, 240 F.3d 1126, $1130-39$ (D.C. Cir.), cert. denied, 122 S. Ct. 644 (2001).

214 Id. at 1133.

215 See S. REP. No. 102-92, at 26 (1992), reprinted in 1992 U.S.C.C.A.N. 1133, 1159 (quoting testimony of Preston Padden); accord Chen, supra note 21, at 1490-91 ("The fear is instinctive and profound: She who controls the networks of the future shall control the terms of speech. She who owns the superhighway shall fetch whatever toll she demands.") 


\section{B. Structural Market Conditions}

As the analysis contained in Part I indicates, both Chicago and postChicago School economists agree that vertical integration is unlikely to harm competition unless certain structural preconditions of the type identified in the Vertical Merger Guidelines are met. ${ }^{216}$ Specifically, the Guidelines require that (1) the primary market be concentrated and that (2) the secondary market be sufficiently concentrated and protected by barriers to entry as to be susceptible to monopolization. Even if these preconditions are met, the Guidelines recognize that vertical integration might still be justified if significant efficiencies exist.

When evaluated against these standards, it becomes relatively clear that the restrictions on vertical integration in the cable industry enacted by the 1992 Cable Act are not economically justified. In fact, a review of the empirical literature studying vertical integration in the cable industry further confirms this conclusion. This Section closes by evaluating the one economically defensible justification for prohibiting vertical integration (i.e., preventing cable operators from evading rate regulation). I conclude that the decline and impending demise of rate regulation of the cable industry has already undercut the relevance of this consideration.

\section{Concentration in the Market for MVPDs}

As noted earlier, the first requirement under the Vertical Merger Guidelines is market concentration in the primary market, which in this case is the market for delivering multichannel television programming into the home. In order to properly make this determination, it is important to clear up a common misconception about the proper way to analyze this problem. This is the assumption that because cable appears to be a natural monopoly, it is a given that the market for MVPDs is highly concentrated.

This misconception is based on the belief that the relevant market for analysis is the local market for distributing MVPD services directly to consumers. If this is the appropriate market, then any restrictions on vertical integration are completely unjustified notwithstanding the fact that many of these markets may be true monopolies. This is because the level of vertical integration has no bearing on the real source of monopoly power in the first instance, which is the existence of the natural monopoly in cable distribution. Even complete vertical integration in the industry would not have any effect on the cable operators' monopoly power vis-àvis consumers and thus would have no effect on the prices the cable operators charge consumers or the quantity and quality of programming

216 See supra Subsection 1.B.1.d. 
that they provide. Thus, if the proper market is the market in which cable operators sell MVPD services to consumers, restrictions on vertical integration amount to little more than rearranging the deck chairs on the Titanic, in that such restrictions would rearrange distribution patterns without having any effect on what is causing the ship is to go down in the first place. On the contrary, even though prohibiting vertical integration might not provide any benefit to consumers, it could inflict considerable harm by preventing firms from achieving certain welfare-enhancing efficiencies.

Remembering that the central concern reflected in the provisions of the 1992 Cable Act under discussion is the cable operators' ability to tie up cable networks can clear up this resulting confusion. The relevant market, then, is not the market in which cable operators sell MVPD services directly to consumers, a market that until recently was purely local in scope. Properly defined, the relevant market is the one in which cable operators purchase video programming from cable programmers, a market that is national in scope. In this market, the fact that a particular cable operator may have a local monopoly is irrelevant so long as each network has access to sufficient other cities around the U.S. As I explained earlier, this is also why I regard the subscriber limits to be primarily vertical in focus. Although the size of a particular MSO will not affect consumer pricing of cable services in any local market, it can affect the national market for cable programming by limiting the size of the market available in the event that a cable programmer is unable to strike a deal with that MSO. Thus, the appropriate unit of analysis, then, is the national market in which MVPDs purchase video programming from cable programmers.

As mentioned earlier, however, a properly defined product market also includes all available substitutes. ${ }^{217}$ FCC policy has long recognized that conventional television broadcasting can act as a substitute for cable television, so long as there are sufficient channels operating. ${ }^{218}$ The transition to digital television will only cause this level of competition to increase. As noted earlier, broadcasters have the option of using their digital channels to send up to six standard-definition digital channels instead of transmitting a single channel of HDTV. ${ }^{219}$ Thus, if it were still

217 See supra note 151 and accompanying text.

218 Reexamination of the Effective Competition Standard for the Regulation of Cable Television Serv. Rates, 6 F.C.C.R. 4545, 4547-51, ๆ7 7-30 (1991) (Report \& Order and Second Further Notice of Proposed Rulemaking) (ruling that broadcast television can provide effective competition to cable so long as viewers can receive six over-the-air channels), superseded by 47 U.S.C. $\$ 543(l)$ (1994). This overturned a previous ruling placing the threshold even lower. Implementation of the Provisions of the Cable Communications Policy Act of 1984, 50 Fed. Reg. 18,637, 18,648-50 (May 2, 1985) (Report \& Order) (ruling that cable operators face "effective competition" whenever they confront at least three over-the-air broadcast stations).

219 See supra note 168 and accompanying text. 
legitimate to continue to apply the standards announced by the FCC in 1991, the presence of even a single conventional television broadcaster may be sufficient to provide some downward price pressure on cable operators.

In addition, Congress and the FCC have each recognized that other MVPDs are properly considered substitutes for cable. ${ }^{220}$ Under current law, a cable operator faces effective competition if another MVPD is available in at least fifty percent of the cable operator's service area and if the MVPD actually serves at least fifteen percent of MVPD households in that area. ${ }^{221}$ After years of unfulfilled predictions, ${ }^{222}$ DBS has finally emerged as a viable competitor to cable, offering a similar number of channels at roughly comparable pricing and offering an array of additional services that cable cannot currently provide. ${ }^{223}$ In addition, the enactment of the Satellite Home Viewer Improvement Amendments of 1999 ("SHVIA") removed one of the most significant impediments to DBS growth by permitting DBS systems to carry local broadcast stations affiliated with the major broadcast networks. ${ }^{224} \mathrm{~A}$ recent FCC empirical study confirmed that, contrary to the findings of studies conducted prior to the enactment of the SHVIA, ${ }^{225}$ DBS is now acting as a substitute to cable television service. ${ }^{226}$

220 See 47 U.S.C. $\$ 543(l)(2)$, (3) (1997); Reexamination of the Effective Competition Standard for the Regulation of Cable Television Serv. Rates, 6 F.C.C.R. 4545, 4551-54, Tf $31-46$ (1991) (Report and Order and Second Further Notice of Proposed Rulemaking) (ruling that a cable operator faces effective competition if another cable system is available in fifty percent of the area's households and if ten percent of those households actually subscribe).

22147 U.S.C. $\$ 543(l)(1)(1994)$.

222 See G. KENT WEBB, THE ECONOMICS OF CABLE TELEVISION 15-16, 181-82 (1983); Jill A. Stem et al., The New Video Marketplace and the Search for a Coherent Regulatory Philosophy, 32 CATH. U. L. ReV. 529, 541-43 (1983); Laurence H. Winer, The Signal Cable Sends-Part I: Why Can't Cable Be More Like Broadcasting?, 46 MD. L. REv. 212, 254-55 (1987).

223 DirecTV's basic package currently offers 105 channels for $\$ 31.99 /$ month, a price that is quite comparable to that charged by conventional cable services. DirecTV is also able to offer a wider array of movie and sports offerings than conventional cable systems. See DirecTV, DirecTV Packages, at http://www.directv.com/packages/packagespages/0,1336,516,00.html (last visited Dec. 12, 2001). The Dish Network, run by Echostar, typically prices its basic 50-channel service at $\$ 21.99 /$ month and its 100-channel service at $\$ 30.99$. At the time of this writing, the Dish Network was offering a promotional price of $\$ 9.00$ /month with free installation on its 100 -channel service. Dish Network, Dish Network Special Offers, at http://www.dishnetwork.com/content/promotions/index.shtml (last visited Dec. 12, 2001).

22417 U.S.C. $\$ \S 119,122$ (Supp. V 1999)

225 See Annual Assessment of the Status of Competition in Mkts. for the Delivery of Video Programming, 15 F.C.C.R. 978, 1012-13, ๆ7 71, 73 (2000) (Sixth Annual Report) [hereinafter Sixth Annual Report]; Austan Goolsbee \& AmIL PETRIN, THE CONSUMER Gains from Direct BROADCAST SATELLITES AND THE COMPETITION WITH CABLE TELEVISION 4, 27-28, 32 (Nat'l Bureau of Econ. Research, Working Paper No. 8317, May 29, 2001), available at http://gsbwww.uchicago.edu/fac/austan.goolsbee/research/satfin.pdf.

226 Specifically, the empirical analysis in the FCC's 2000 Report on Cable Industry Prices concluded that the demand for cable is somewhat price elastic, which suggests that there are substitutes for cable service. Implementation of Section 3 of the Cable Television Consumer Protection and Competition Act of 1992, 16 F.C.C.R. 4346, 4363, 148 (2001) (Report on Cable Industry Prices). The 
The effect has been striking. For the last several years, DBS subscribership has grown at a rate nearly twenty times that of cable subscribership. As Table I indicates, ${ }^{227}$ on a national level, DBS has now surpassed the level required by Congress to represent effective competition to cable operators, capturing eighteen percent of the MVPD market. ${ }^{228}$ Since DBS is in essence available to all U.S. households, the national numbers suggest that cable operators probably face effective competition in a large number of communities throughout the country. It appears to just be a matter of time until the monopoly control that cable operators have long exerted over the MVPD market completely erodes.

When DBS is included in the same product market as cable, it becomes clear that the MVPD market is too unconcentrated to support a credible leveraging argument. Once DBS and other MVPDs are included, the HHI of the national market for the purchase of video programming drops to 905, a level considered unconcentrated under the merger guidelines. $^{229}$

It thus appears that the national market for MVPDs is already too unconcentrated to support the conclusion that vertical integration could have any anti-competitive effects. The impending arrival of video-ondemand via the Internet promises to deconcentrate this market still further.

addition of a DBS coefficient to the model confirmed that DBS was in fact a substitute for cable service, since the presence of DBS was found to cause a statistically significant reduction in cable subscribership. Id. at 4364-65, ๆ 53.

227 Supra notes 153-155 and accompanying text.

228 National Cable \& Telecommunications Association, Cable \& Telecommunications Industry Overview 14 (2001), at http://www.ncta.com/pdf_files/Ind_Ovrvw_060801.pdf.

229 Recent HHls have been on a downward trajectory. See Eighth Annual Report, supra note 151 , at 100 tbl.C-4 (reporting HHIs of 954 for the year 2000, 923 for the year 1999, and 1096 for the year 1998); Annual Assessment of the Status of Competition in Mkts. for the Delivery of Video Programming, 13 F.C.C.R. 1034, 1121, I 155 (1998) (Fourth Annual Report) [hereinafter Fourth Annual Report] (reporting HHIs of 1166 for 1997 and 1013 for 1996); Annual Assessment of the Status of Competition in Mkts for the Delivery of Video Programming, 11 F.C.C.R. 2060, 2126-27, If $139-40$ (1997) (Second Annual Report) [hereinafter Second Annual Report] (reporting HHIs of 1098 for 1995 and 898 for 1994); 1990 Report on Cable Competition, supra note 207, at 5106 tbl.I (reporting HHI of 975 for 1990). It aiso treats AT\&T Broadband and Time Warner Cable as separate entities, even though AT\&T owns a twenty-four percent stake in Time Wamer Entertainment, since AT\&T has announced its intention to sell this holding. See Diane Mermigas, Schleyer's Charge: Keeping Status Quo, ELEC. MEDIA, Oct. 29, 2001, at 20.

EchoStar announced its plans to acquire Hughes's DirecTV unit. See Nikhil Deogun \& Andy Pasztor, GM Agrees to Sell Hughes to EchoStar, WALL ST. J., Oct. 29, 2001, at A3. In addition, AT\&T announced that it was selling its cable holdings to Comcast. See Deborah Solomon \& Robert Frank, AT\&T Picks Comcast to Get Cable Unit, WALL ST. J., Dec. 20, 2001, at A3. Even if these companies were to complete their mergers, total HHI would only increase to 1374 , still well below the 1800 level identified by the Vertical Merger Guidelines as the threshold for anti-competitive concem. 
Table IV. Concentration in the National Market for Purchase of Video Programming as of June 30, 2001

\begin{tabular}{lrr}
\hline $\begin{array}{lr}\text { Multichannel Video Programming } \\
\text { Distributor ("MVPD") }\end{array}$ & Share & HHI \\
\hline & & \\
AT\&T Broadband & $16.44 \%$ & 270 \\
Time Warner Cable & $14.35 \%$ & 206 \\
Hughes Electronics Corp. & $11.32 \%$ & 128 \\
Comcast Cable Communications & $9.53 \%$ & 91 \\
Charter Communications & $7.35 \%$ & 54 \\
EchoStar Communications & $6.98 \%$ & 49 \\
Cox Communications & $6.87 \%$ & 47 \\
Adelphia Communications & $6.51 \%$ & 42 \\
Cablevision Systems Corp. & $3.40 \%$ & 12 \\
Insight Communications & $1.54 \%$ & 2 \\
Other & $15.71 \%$ & 4 \\
& & \\
Total & $100.00 \%$ & 905 \\
\hline
\end{tabular}

Source: Eighth Annual Report, supra note 151, at 98 tbl.C-3.

2. Concentration and Barriers to Entry into the Market for Television Networks

The second structural precondition is that the secondary market-in this case, the market for cable networks-must be concentrated and protected by barriers to entry. An analysis of the industry strongly suggests that this precondition is not met either. As Subsection I.C.1 covers in some detail, the concentration levels in the market for television networks appear to fall below the thresholds established by the Vertical Merger Guidelines.

Indeed, the market for cable networks appears to be extremely elastic. The factors of production used to create these networks-talent and communication hardware-are readily available in markets already highly organized to supply these same inputs to other industries. ${ }^{230}$ The empirical record supports this conclusion as well. As Table V indicates, there are currently more than 294 cable networks operating in the U.S., and the FCC reports that an additional fifty-one networks are in the planning stages. ${ }^{231}$ In addition, the total number of cable networks has increased by more than

230 OWEN \& WILDMAN, supra note 169, at 222.

231 Eighth Annual Report, supra note 151, at 67, ๆ 160. 
four times over the last decade, and the level of vertical integration has dropped steadily as well. In the face of such data, it becomes all but impossible to maintain the existence of any significant barriers to entry into the market for cable networks.

\section{Table V. Vertical Integration of Cable Networks}

\begin{tabular}{|c|c|c|c|c|c|c|c|c|c|}
\hline & 1990 & 1994 & 1995 & 1996 & 1997 & 1998 & 1999 & 2000 & 2001 \\
\hline Total Networks & 70 & 106 & 129 & 147 & 172 & 245 & 283 & 281 & 294 \\
\hline Vertically Integrated Networks & 35 & 56 & 66 & 67 & 68 & 95 & 104 & 99 & 104 \\
\hline Pct. Vertically Integrated & $50 \%$ & $53 \%$ & $51 \%$ & $46 \%$ & $40 \%$ & $39 \%$ & $37 \%$ & $35 \%$ & $35 \%$ \\
\hline $\begin{array}{l}\text { Among Top } 15 \text { Networks by } \\
\text { Audience }\end{array}$ & 10 & 12 & 11 & 8 & 7 & 9 & 8 & 6 & 7 \\
\hline $\begin{array}{l}\text { Among Top } 20 \text { Networks by } \\
\text { Subscribers }\end{array}$ & 13 & 14 & 13 & 9 & 8 & 9 & 8 & 9 & 9 \\
\hline
\end{tabular}

Sources: Eighth Annual Report, supra note 151, at 66, I 157, 120-21 tbls.D-6 \& D-7; Annual Assessment of the Status of Competition in the Mkts. for the Delivery of Video Programming, 16 F.C.C.R. 6005, 6078-79, I 173, 6138-39 tbls.D-6 \& D-7 (2001) (Seventh Annual Report); Sixth Annual Report, supra note 225, 1057-58, ๆ 179, $1119-20$ tbls.D-6 \& D-7; Annual Assessment of the Status of Competition in Markets for the Delivery of Video Programming, 13 F.C.C.R. 24,284, 24,376, If 159 (1998) (Fifth Annual Report); Fourth Annual Report, supra note 229, 1122, I 158, $1231-34$ tbls.F-6 \& F-7; Annual Assessment of the Status of Competition in Mkts. for the Delivery of Video Programming, 12 F.C.C.R. 4358, 4429-30, ๆ 142, 4470-81 tbls.6 \& 7 (1997) (Third Annual Report); Second Annual Report, supra note 229, 2132, ๆ 150, 2163-64 tbls.6 \& 7; Annual Assessment of the Status of Competition in Mkts. for the Delivery of Video Programming, 9 F.C.C.R. 7442, 7522-23, \{โ161-62 \& n.434, 7526, $\{167$ (1994) (First Report); 1990 Report on Cable Competition, supra note 207, 5109-14 tbls.4, 5, $7 \& 8$.

That said, this conclusion is not unassailable. Some economists have long maintained that, when a market involves differentiated products, it is possible that all networks do not compete with one another equally and that submarkets may exist within the overall market for cable programmers. ${ }^{232}$ Indeed, there is substantial anecdotal evidence that certain networks, such as ESPN and CNN, may for all practical purposes be essential and have few real substitutes ${ }^{233}$ and that vertical integration

232 The seminal submarket case is Brown Shoe Co. v. United States, 370 U.S. 294, 325 (1962). Although it has largely lain fallow for some time, a number of recent cases have renewed interest in it. See Eastman Kodak v. Image Technical Servs., 504 U.S. 451, 464-65 (1992); Aspen Skiing Co. v. Aspen Highlands Sking Corp., 472 U.S. 585, 596 n.20 (1985); FTC v. Staples, Inc., 970 F. Supp. 1066, 1075 (D.D.C. 1997). For recent articles favoring the use of submarket analysis, see Jonathan B. Baker, Stepping Out in an Old Brown Shoe: In Qualified Praise of Submarkets, 68 Antitrust L.J. 203 (2000); and Thomas J. Campbell, Predation and Competition in Antitrust: The Case of Nonfungible Goods, 87 CoLUM L. REv. 1625 (1987). For recent analyses appiying submarket theory to electronic communications, see Patrick Bolton et al., Predatory Pricing: Strategic Theory and Legal Policy, 88 GEO. L.J. 2239, 2293-98 (2000); and James E. Meeks, Predatory Behavior as an Exclusionary Device in the Emerging Telecommunications Industry, 33 WAKE FOREST L. REV. 125, 132 (1998).

233 See S. REP. No. 102-92, at 24 (1992), reprinted in 1992 U.S.C.C.A.N. 1133, 1157; see also WATERMAN \& WEISS, supra note 21 , at 130 ("Although clearly an empirical question, there 
permitted some companies to forestall competition from networks that directly competed with their own, vertically integrated networks. ${ }^{234}$ Indeed, as recounted below, recent studies have lent some empirical support for the proposition. ${ }^{235}$ Submarket theory has its share of critics, however. A number of leading antitrust scholars have condemned it as a superfluous and confusing doctrine that adds nothing to the conventional analysis of what is a proper market while raising the danger that the relevant market will be defined too narrowly. ${ }^{236}$

Resolution of the controversy over the proper role of submarkets in antitrust analysis exceeds the scope of this Article. For current purposes, it suffices to point out that, even if submarket theory were accepted for all it is worth, it would not support the enactment of the prohibitions of vertical integration contained in the 1992 Cable Act. The existence of submarkets would justify intervening with respect to vertical integration involving only those cable networks that comprised the submarket, such as CNN or ESPN. It would not justify the indiscriminate type of prohibition of all vertical integration without regard to the type of programming involved that is embodied in the 1992 Cable Act.

\section{Potential Efficiency Justifications for Vertical Integration in the Cable Industry}

The final stage of the basic analytical approach described above is an assessment of whether vertical integration is likely to permit firms to realize efficiencies. Given the similarity of the cost structures involved, it should come as no surprise that the potential efficiencies resulting from vertical integration in the cable industry are quite similar to those created by vertical integration in broadcast television. Just as was the case in broadcasting, the large, up-front costs associated with creating each program make it especially important that cable programmers be able to

\footnotetext{
seems to be a consensus in the industry that the lack of more than one or two of the most well-known networks would seriously handicap a multichannel competitor to an established cable system.").

234 See WATERMAN \& Weiss, supra note 21, at 55-56, 68-69 (describing Time Warner's efforts to prevent entry of a general news service that would compete directly with CNN); Tasneem Chipty, Vertical Integration, Market Foreclosure, and Consumer Welfare in the Cable Television Industry, 91 AM. ECON. REV. 428, 429 \& n.7, 437 (2001).

235 See infra Subsection II.B.5.a.

236 See 2A PHILlip E. AREEDA, HERBert HovenkaMP \& JoHN L. SOlow, ANTITRUST LAW T553c, at 167, 172-77, (1995); Phillip Areeda, Monopolization, Mergers, and Markets: A Century Past and Future, 75 CAL. L. Rev. 959, 979-80 (1987); David A. Balto, Antitrust Enforcement in the Clinton Administration, 9 CORNELl J.L. \& PUB. POL'Y 61, 73 n.63 (1999); Lawrence C. Maisel, Submarkets in Merger and Monopolization Cases, 72 GEO. L.J. 39 (1983); Timothy J. Muris, Economics and Antitrust, 5 GEO. MASON L. REV. 303, 312 (1997); Joshua A. Newberg, Antitrust for the Economy of Ideas: The Logic of Technology Markets, 14 HARV. J.L. \& TECH. 83, 90 n.27 (2000); see also Rothery Storage \& Van Co. v. Atlas Van Lines, 792 F.2d 210, 218 n.4 (D.C. Cir. 1986), cert. denied, 479 U.S. 1033 (1987).
} 
obtain guaranteed distribution before making their initial investments in the programming. In addition, cable programming exhibits the same type of product complementarities as broadcast programming. As a result, the potential efficiencies resulting from vertical integration end up being quite comparable.

\section{a. Elimination of Static Transaction Costs and Double Marginalization}

Importance of Guaranteed Distribution. First, as was the case in broadcasting, ${ }^{237}$ the existence of large, up-front, first-copy costs for producing cable programming and the relatively low marginal costs associated with conveying the program to another viewer causes costs to decline across all relevant volumes. As a result, cable programming exhibits a natural tendency towards broad-scale distribution, since profitability now depends upon amortizing the fixed cost investment across as many sales as possible. ${ }^{238}$

The existence of such fixed costs makes access to a large portion of the market one of the primary determinants of economic success. Programmers who can obtain guaranteed distribution have substantial incentive to make efficient investments in programming. Conversely, cable programmers that lack a guaranteed market face risks that can depress investment in programming below optimal levels. ${ }^{239}$ These considerations are particularly important for new networks, which face even greater risks. Guaranteed distribution allows new networks to invest in their programs with greater confidence. ${ }^{240}$ Indeed, industry participants confirm that vertical integration was essential in getting programming stars such as CNN, C-Span, the Discovery Channel, BET, and TNT off the ground. ${ }^{241}$

The efficient functioning of the cable industry thus depends in no small part on the ability of cable programmers to ensure that they will have access to a sufficient number of cable operators. This is not to say that all programmers must secure universal distribution or that programming must capture a dominant share in order to be viable. Indeed, minimum viable

237 See supra Subsection I.A.3.a.

58.

238 See OWEN \& WILDMAN, supra note 169, at 245; WATERMAN \& WEISS, supra note 21, at

239 Leland Johnson, TOWARD COMPETITION IN CABle TeleVision 60 (1994); OWEN \& WILDMAN, supra note 169, at 245; WATERMAN \& WEISS, supra note 21 , at $61 \mathrm{n} .11$; Olson \& Spiwak, supra note 21 , at 291.

240 WATERMAN \& WEISS, supra note 21, at 132.

241 See 1990 Report on Cable Competition, supra note 207, at 5009, ๆ 83, 5037, ๆ 144(a); David Waterman, Vertical Integration and Program Access in the Cable Television Industry, 47 FED. Сомм. L.J. 511, 520 (1995). 
scale appears to be small relative to the national market. ${ }^{242}$ My point is that the equilibrium levels for cable programming will exhibit a natural propensity towards as wide a distribution as possible and that artificial limits on cable programmers' ability to secure such distribution may lead them to underinvest in programming. Although it is possible that policy makers could turn to regulation to guarantee such access, it is also possible that private ordering would be even more effective. For example, cable programmers could use contractual provisions to guarantee such access. Doing so would involve a large number of such negotiations that can lead to significant transaction costs. In addition, the inevitable incompleteness of these contracts would leave the parties unable to eliminate all of these risks. If these transaction costs are significant enough, cable programmers may find it more efficient to internalize those transactions within the boundaries of a single firm and instead use vertical integration to guarantee the access that they need in order to make efficient program investments. ${ }^{243}$

Programming Complementarities. In addition, bringing transmission and content under the same corporate umbrella can help control for the fact that the value of a particular cable network is not simply a function of its own intrinsic qualities, but depends as well on what other networks are being provided. The solution to this problem is simple. Allowing cable operators the freedom to choose what programming they will convey effectively internalizes these externalities by bringing them all under joint control. Conversely, restrictions limiting the cable operator's ability to refuse to carry particular programming (such as the must-carry and leased access provisions contained in the 1992 Cable Act) can lead to -a suboptimal program mix. This is particularly true where products are risky and difficult to value in advance, as is the case here. ${ }^{244}$

The Problem of Double Marginalization. As noted earlier, vertical integration can enhance efficiency by allowing the integrated firm to transfer inputs at marginal cost. ${ }^{245}$ In the case of cable television, the marginal cost of duplicating and distributing programming to additional viewers is arguably so close to zero that any attempt to charge a positive price can reduce net economic welfare. Bringing programming and distribution under the same corporate umbrella draws attention away from the transfer price charged for programming and leads the vertically integrated entity to maximize its profits solely in terms of the price of the

242 Time Warner Entm't Co. v. FCC, 240 F.3d 1126, $1130-39$ (D.C. Cir.), cert denied, $122 \mathrm{~S}$. Ct. 644 (2001).

2431990 Report on Cable Competition, supra note 207, at 5009, T 84; OWEN \& WILDMAN, supra note 169, at 245; Chipty, supra note 234, at 431-32.

244 See OWEN \& WILDMAN, supra note 169 , at $220,245$.

245 See supra notes 84-88 and accompanying text. 
final good. In so doing, vertical integration has the potential to yield a more economically efficient result.

\section{b. Elimination of Strategic Behavior}

In addition, the existence of large sunk costs and externalities creates the danger that cable programmers and cable operators will act opportunistically in an attempt to capture a greater percentage of the available profits. Vertical integration and vertical contractual restraints can allow cable programmers and cable operators to avoid incurring the transaction costs associated with protecting themselves against this possibility.

Hold Up. As noted earlier, the sunk cost investments needed to create original programming expose cable programmers to the possibility of opportunistic behavior. Cable programmers will not invest in programming unless it is likely that they will be able to recover both the fixed costs associated with creating the programming as well as the marginal costs of distribution. Once the first-copy costs are sunk, however, it is possible for the cable operators to hold out ex post in an attempt to drive price down to marginal cost. Thus, the danger of being unable to recover sunk costs can lead cable programmers that are unable to protect themselves ex ante against this possibility not to invest in creating new programming even when doing so would enhance welfare. While it is theoretically possible to use contractual devices to guard against such opportunistic behavior, such contracts may be costly to negotiate and, in any event, will not be able to anticipate every possible contingency. Thus, if the levels of risk and the costs of negotiation are relatively high, it may be more efficient for firms to use vertical integration to protect themselves against such sunk cost opportunism, since any attempt to hold up would simply redistribute profits between levels of production without having any effect on the firm's overall return. ${ }^{246}$

Free Riding. There appear to be two different ways in which free riding may lead to a systematic underinvestment in cable programming. First, cable operators have the incentive to attempt to free ride on other cable operators' contribution to the first-copy costs of production. Efficient production of any high fixed cost good requires all those purchasing that good to bear part of those fixed costs. Cable operators, however, have the incentive to shirk on bearing those costs. Ideally, a cable operator would prefer to rely on other cable operators to cover the up-front costs

246 Id. (citing Franklin M. Fisher, The Financial Interest and Syndication Rules in Network Television: Regulatory Fantasy and Reality, in ANTITRUST AND REGULATION 263, 273 (Franklin M. Fisher ed., 1985)); WATERMAN \& WEISS, supra note 21, at 47; Olson \& Spiwak, supra note 21, at 290-91. 
associated with creating the program in the first instance and would simply pay the marginal costs associated with distributing the program. Even though such free riding also causes a decline in the attractiveness in the cable operator's own programming, the decline would only be in proportion to its share of the national market. Although the various cable operators around the country would mutually benefit from restoring the investment in programming to efficient levels, the transaction costs associated with forging and monitoring such an agreement would potentially be huge. Since tying the fortunes of the cable operators and the cable programmers together allows the cable operator to internalize the negative externality effect on program supply, thereby reducing the cable operators' incentives to shirk in the first instance, vertical integration offers another way for cable programmers to solve this problem. ${ }^{247}$

Second, even cable operators who do not shirk on price may attempt to free ride on the promotional efforts of other cable operators. ${ }^{248}$ Like most industries, there is an optimal level of promotion for the cable industry. Promotional efforts have the effect of increasing the market, which in turn allows the fixed costs to be spread over a larger viewer base. However, as before, cable operators do not capture all of that benefit, gaining only in proportion to national market share. Again, the ideal position for a cable operator is for other cable operators to undertake the promotional efforts necessary to build the audience for a particular network to its optimal level, while that operator gains the benefit of the efforts of other operators while simultaneously avoiding paying the costs of promotion. In other words, it attempts to free ride on the promotional efforts of other operators. If enough operators shirk in this manner, the industry will offer a suboptimal level of promotion. Even though all would be better off if they could mutually agree to engage in higher levels of promotional activity, there is no mechanism through which the various operators could coordinate their actions, and, even if there were, the costs of forging and enforcing such an agreement would likely be large. Thus, even a cable operator who foregoes the opportunity to free ride in terms of contribution to fixed costs may attempt to free ride in terms of promotion. Again, vertical integration has the potential of eliminating the incentives for shirking, since doing so would internalize both the gains and losses from shirking within the same firm. ${ }^{249}$

247 WATERMAN \& WEISS, supra note 21 , at 74-76. Waterman and Weiss also offer a formal model of this problem. Id. at 78-86.

248 See generally supra notes 97-99 and accompanying text (discussing Lester Telser's pathbreaking work on free riding on promotional activities).

249 See 1990 Report on Cable Competition, supra note 207, at 5010, ๆ 86; Waterman, supra note 241 , at 521 . 
Again, it bears repeating that it is not my purpose to argue that such transaction cost efficiencies actually exist. As I noted earlier, the existence of such benefits is far from uncontrovertible. ${ }^{250}$ My point is simply that such efficiencies are sufficiently plausible to justify hesitating before erecting any regulatory barriers to vertical integration in the cable industry. Such considerations are better handled in the case-by-case context of an antitrust court applying the rule of reason than through the more categorical per se approach represented by a regulatory solution.

\section{The Special Problem of Rate Regulation}

There is one significant risk resulting from vertical integration in the cable television industry that does not exist with respect to the broadcast television industry. As noted earlier, the existence of rate regulation at one level of production can provide a substantial anti-competitive motive for vertical integration or vertical restraints. This is because a monopolist who is barred by rate regulation from earning all of the available monopoly profits in one market can attempt to tie its product to an unregulated product in an adjacent, competitive market. In the absence of rate regulation on the second level, vertical integration could thus allow the monopolist to evade the consequences of regulation altogether. ${ }^{251}$ As commentators have pointed out in the past, cable operators facing rate regulation at the retail level may have an incentive to vertically integrate backwards into programming. ${ }^{252}$

Recent changes in the regulatory and technological environment have effectively rendered this argument toothless. This is because a provision included in the Telecommunications Act of 1996 eliminated rate regulation of all but the basic tier of cable programming services. ${ }^{253}$ Even the basic tier is subject to deregulation if a cable operator faces competition from another MVPD that can reach fifty percent of the households in the cable operator's franchise area and actually reaches fifteen percent of those households. ${ }^{254}$ The emergence of DBS as a major competitor to cable makes it extremely likely that rate regulation will soon come to an end in most cities, since DBS is essentially universally available and, as Table I indicates, has already surpassed the fifteen percent threshold required under the statute on a nationwide level. ${ }^{255}$ As a

250 See supra notes $108-114$ and accompanying text.

251 See supra note 80 and accompanying text.

252 See J.A. Ordover et al., Nonprice Anticompetitive Behavior by Dominant Firms Toward the Producers of Complementary Products, in ANTITRUST AND REGULATION, supra note 246, at 115 , 127-28.

25347 U.S.C. $\$ 543(\mathrm{a})(1)$, (b) (1994).

254 Id. $\S 543(D)(1)(\mathrm{B})$.

255 See supra Subsection I.C.1. 
result, this argument will likely soon be rendered moot, since the elimination of rate regulation would effectively undercut its core premise.

\section{Empirical Evidence on Vertical Integration in the Cable Industry}

It thus appears as a matter of theory that, in the cable industry, as it is currently structured, vertical integration is unlikely to harm competition. On the contrary, the existence of potential transaction cost savings flowing from vertical integration suggests that, if anything, the various limits on vertical integration imposed by the 1992 Cable Acts may actually be harming consumers. With regard to cable, however, we have the benefit of more than just theory. There is an excellent body of empirical work studying the impact of vertical integration on the cable industry. These studies provide us with greater insight into the potential anti-competitive impact of vertical integration identified in theoretical literature.

\section{a. Efficiency Effects vs. Strategic Effects}

Of particular interest for our purposes is a group of studies examining the overall impact of vertical integration on competition. ${ }^{256}$ There have been two lines to these studies, one focusing on basic cable networks and the other focusing on premium cable networks. A recent article by Tasneem Chipty brings both of these lines of empirical inquiry together in insightful ways. ${ }^{257}$ What is most singular about Chipty's work, however, is its attempt to evaluate the overall impact that the various pro-competitive and anti-competitive effects have on total consumer surplus.

The methodologies underlying these lines of study are similar. ${ }^{258}$ They begin by comparing the carriage decisions of vertically integrated cable operators and non-vertically integrated cable operators. Unsurprisingly, these studies uniformly found that cable operators were more likely to carry networks with which they were vertically affiliated. The greater willingness to carry vertically affiliated networks is ultimately ambiguous, however, since it is consistent with both foreclosure (i.e., the operator is trying to use vertical integration to prevent the emergence of new competitors) and an efficiency justification (i.e., vertical integration

256 For discussions of the early empirical work on the cable industry, see OWEN \& WILDMAN, supra note 169, at 246-50; see also Klass \& Salinger, supra note 128, at 692.

257 Chipty, supra note 234.

258 The only other paper of which I am aware that attempted to analyze the welfare impact of vertical integration in the cable industry is George S. Ford \& John D. Jackson, Horizontal Concentration and Vertical Integration in the Cable Television Industry, 12 REV. INDUS. ORG. 501 (1997). Ford and Jackson concluded that, although vertical integration lowered programming costs, it also led to an overall increase in the price charged to consumers that on balance caused consumer welfare to drop. Ford and Jackson's analysis was limited to a single, own-price effect. 
allows the realization of cost reductions that makes the vertically affiliated network more attractive than the unaffiliated network).

These studies solved this conundrum by also looking at the willingness of vertically integrated cable operators to carry unaffiliated networks. If vertical integration were motivated by foreclosure, one would expect that the increased willingness to carry affiliated networks be offset by a decreased willingness to carry unaffiliated networks. In contrast, if vertical integration were motivated by efficiency concerns, one would expect that the increased willingness to carry vertically affiliated networks would be matched by an increased willingness to carry unaffiliated networks, since the cost savings would allow the cable operator to engage in more efficient operations.

The conclusions drawn by these initial studies differed with respect to basic cable and premium cable networks. With respect to basic cable networks, the early studies by Benjamin Klein, Robert Crandall, and the National Telecommunications and Information Administration uniformly found the evidence to be more consistent with an efficiency story than a foreclosure story. Each study found that greater willingness to carry affiliated networks was correlated with a greater willingness to carry unaffiliated programming. Since any pure foreclosure story would have required a reduction in the amount of unaffiliated programming carried, these studies rejected the notion that vertically integrated cable operators were engaging in any systematic discrimination against unaffiliated programmers. ${ }^{259}$

Studies of premium cable networks tended to draw the opposite conclusion. For example, a 1997 study by David Waterman and Andrew Weiss found that vertical integration with premium cable networks did tend to lead to some foreclosure, since vertically integrated cable operators were simultaneously more likely to carry affiliated premium networks and less likely to carry unaffiliated premium networks. ${ }^{260}$ In addition, vertical integration appeared to reduce the total number of networks carried by the cable operator. ${ }^{261}$ Waterman and Weiss were unable to determine whether these effects indicated that vertical integration on the whole yielded procompetitive or anti-competitive effects. ${ }^{262}$

Chipty's study confirmed and extended these conclusions, by finding evidence indicating that vertical integration had both competitive and anti-

259 OWEN \& WILDMAN, supra note 169, at 246-50 (describing these studies).

260 WATERMAN \& WEISS, supra note 21 , at 90 . For an earlier version of this study, see David Waterman \& Andrew A. Weiss, The Effects of Vertical Integration Between Cable Television Systems and Pay Cable Networks: 1988-1989, 72 J. ECONOMETRICS 357 (1996).

261 WATERMAN \& WEISS, supra note 21 , at $98-100$.

262 Id. at 103, 105, 142-43; see also OWEN \& WILDMAN, supra note 169, at 246 (noting that a study conducted by Michael Salinger found some evidence of discrimination by vertically integrated MSOs against competing premium movie channels). 
competitive effects. To determine the possible anti-competitive effects, Chipty measured the extent to which certain cable operators carried a home shopping channel with which they were vertically integrated (QVC) and compared it with the extent to which those same operators carried a home shopping channel with which they were not vertically affiliated (HSN). Chipty found that cable operators that were vertically integrated with QVC were simultaneously more likely to carry QVC and less likely to carry HSN than were non-vertically affiliated cable operators. ${ }^{263}$ Chipty similarly found that vertically integrated cable operators were more likely to carry premium cable networks with which they were vertically integrated and less likely to carry unaffiliated cable services that compete directly with those networks. ${ }^{264}$ Thus, Chipty concluded that vertical integration, regardless of whether it involves basic or premium cable networks, does result in some degree of market foreclosure. ${ }^{265}$

At the same time, however, Chipty found significant evidence that vertical integration yielded efficiencies. First, if vertical integration did not yield efficiencies, one would not expect it to have any effect on the total number of networks that a particular cable operator carried. Chipty found, however, that cable operators that were vertically integrated with basic cable networks tended to carry more total networks than non-vertically integrated cable operators, a result indicating that vertical integration leads to some gains in efficiency. ${ }^{266}$ Second, if vertical integration were driven solely by anti-competitive motives, one would expect to see those vertically integrated cable operators who had already decided to carry a home shopping network to replace HSN with QVC. Absent some efficiency gains from vertical integration, one would not expect foreclosure to make it any more or any less likely that any given cable operator would carry a home shopping network in the first instance. Chipty found, however, that vertical integration did significantly increase the likelihood that cable operators would carry a home shopping network. Such a result would not have occurred unless vertical integration had provided sufficient efficiencies to change the basic economics of the carriage decision. ${ }^{267}$ Lastly, Chipty compared the vertically integrated cable operators' success in signing up cable subscribers with that of nonvertically integrated cable operators. If no promotional efficiencies resulted from vertical integration, one would not expect vertically integrated operators to have any more success in attracting customers than

263 Chipty, supra note 234 , at $437-39$.

264 Id. at 439.

265 Id. at $429,439-40,450$

266 Id. at $433,435-36,450$. This conclusion applied only to cable operators that were vertically integrated only with basic cable networks. Cable operators that were also vertically integrated with premium cable networks tended to offer fewer networks. Id. at 450 .

267 Id. at $439,450$. 
non-vertically integrated cable operators. Chipty found, however, that cable operators that were vertically integrated with cable programmers were significantly more successful in signing up customers than were nonvertically integrated cable operators, a result that suggested that vertical integration does yield efficiencies in cable operators' ability to promote cable services. ${ }^{268}$

Most importantly for our purposes, Chipty conducted a series of welfare calculations to determine whether the pro-competitive effects dominated the anti-competitive effects or vice versa. These calculations uniformly indicated that vertical integration had a positive impact on consumer welfare, and the majority of these calculations found the positive impact to be statistically significant. ${ }^{269}$ These findings ultimately led Chipty to conclude that vertical integration does not harm consumers; if anything, it may provide substantial benefits to them. ${ }^{270}$

\section{b. Vertical Integration vs. Vertical Restraints}

The empirical literature on cable television also addressed a separate question. As noted earlier, a cable operator seeking to use vertical integration to harm competition can do so in two ways. First, it can vertically integrate with an essential cable network and refuse to offer that network to any competing MVPD. Alternatively, it can forego vertical integration and instead simply enter into a contract with a key cable network that either guarantees exclusivity or requires the network to charge competing MVPDs prohibitively high prices. If cable operators could achieve the same anti-competitive effects through vertical contractual restraints as vertical integration, then it is thus theoretically arguable that the presence or absence of vertical integration is actually irrelevant. The real source of market power would flow from horizontal concentration in the national market for the purchase of video programming at the MSO level. The presence or absence of vertical integration would not affect the leverage provided by this horizontal market power in any way. ${ }^{271}$ Although, under this argument, vertical integration would have no impact on the anti-competitive effects, it would still have potentially profound effects on the firms' ability to realize the available pro-competitive benefits. As discussed earlier, vertical integration can enable firms to achieve greater efficiencies than vertical

268 Id. at $443,450$.

269 Id. at $448-49$.

270 Id. at $430,449-50$.

271 See OWEN \& WILDMAN, supra note 169, at 221-22; WATERMAN \& WEISS, supra note 21 , at $56-57,67,129-32$. Note that the statutory prohibition of exclusive dealing applies only to vertically integrated operators. See 47 U.S.C. $\$ 548$ (c) (1994). As a result, all non-vertically integrated operators remain free to pursue vertical integration or exclusive dealing strategies. 
contractual restraints. Thus, although the choice of strategies arguably has negligible impact on competition, the potential impact on the procompetitive effects may be profound.

Waterman and Weiss designed an empirical study to test this argument. ${ }^{272}$ If the real source of anti-competitive behavior were vertical integration and not horizontal market power, one would expect vertically integrated programmers to enter into a higher percentage of exclusive dealing contracts than non-vertically integrated programmers. However, if the real source of market power were vertical integration rather than horizontal concentration, one would expect the price premium charged by vertically integrated programmers to be higher than that charged by nonvertically integrated programmers.

Waterman and Weiss's study refuted the notion that vertical integration was the source of anti-competitive market power. Although this consideration was largely rendered moot by the industry-wide abandonment of exclusive dealing contracts in the early 1990s, their review of the available empirical evidence revealed that both vertically integrated and non-vertically integrated cable programmers were similarly prone to enter into exclusive dealing contracts. ${ }^{273}$ More important were their findings regarding the size of the premium charged to competing MVPDs. A review of the prices charged to two different types of competing MVPDs revealed that there was no significant difference between the premium charged by vertically integrated cable programmers and the premium charged by non-vertically integrated cable programmers. ${ }^{274}$ Waterman and Weiss thus found that vertically integrated and non-vertically integrated firms exhibited precisely the same type of potentially anti-competitive behavior. As a result, they concluded that there was no reasonable justification for treating vertically integrated firms in a different manner than non-vertically integrated firms. In either situation, the ability to harm competition stemmed from the horizontal market power possessed by the cable operators and not from the vertical practice employed. ${ }^{275}$

In sum, both the theory and the empirical evidence suggest that vertical integration is unlikely to harm competition in the cable industry. As a result, the restrictions on vertical integration contained in the 1992 Cable Act appear to be unjustified. Indeed, there is great irony in the suggestion that cable networks are too weak to confront cable operators, since the broadcast regulations discussed in Part I are based on the exact

272 See WATERMAN \& WEISS, supra note 21 , at 132-41. For an earlier version of this study, see Waterman, supra note 241 .

273 WATERMAN \& WEISS, supra note 21 , at 134-35

274 Id. at $133,138$.

275 Id. at 147. 
opposite assumption. In broadcasting, the fear was that powerful networks would overwhelm the local entities responsible for delivering the programming to the home. In cable, the concern is that powerful local video distributors will overwhelm the poor, hapless networks. Given the substitutability of cable and broadcasting, both of these propositions cannot hold simultaneously. It seems that policy makers are trying to have it both ways.

\section{The Problematic Nature of Compelled Access}

As noted earlier, one of the most distinctive features of the restrictions on vertical integration contained in the 1992 Cable Act is the imposition of compelled access requirements. For example, the must-carry provisions require cable operators to provide free carriage to all full-power local television stations. ${ }^{276}$ In addition, both cable operators and cable programmers must make their facilities available to unaffiliated parties on reasonable and non-discriminatory terms. ${ }^{277}$ In essence, access is the regulatory analog to the "essential facility doctrine" developed under antitrust law. The concern is that cable companies will use their control over the monopoly bottleneck in transmitting multichannel programming to harm competition in the market for cable programming. ${ }^{278}$

Some scholars have lauded the imposition of access requirements on local cable operators as a salutary development. ${ }^{279}$ Indeed, the shift to access may represent a fundamental change in approach to regulatory policy. A recent survey of the regulatory changes taking place in six different regulated industries conducted by Joseph Kearney and Thomas Merrill identified compelled access to monopoly facilities as one of the central features of what they view as a new regulated industries paradigm. ${ }^{280}$

I take a less sanguine view of these developments, however. In fact, I believe that the access requirements imposed by the 1992 Cable Act suffer from several conceptual and practical problems that undercut its utility as a basis for media regulation.

27647 U.S.C. $\$ \S 534,535(1994)$.

277 Id. $\S \S 532$ (leased access), 548(c)(2)(B) (program access).

278 See Turner Broad. Sys., Inc. v. FCC, 512 U.S. 622, 670 (1994) (Stevens, J., concurring); OWEN \& WILDMAN, supra note 169, at 236-40.

279 See, e.g., Jerome A. Barron, The Electronic Media and the Flight From First Amendment Doctrine: Justice Breyer's New Balancing Approach, 31 U. MICH. J.L. REFORM 817 (1998); Timothy J. Brennan, Vertical Integration, Monopoly, and the First Amendment, 4 J. MEDIA ECON. 57 (1990); Chen, supra note 21 , at $1498-99$.

280 Kearney \& Merrill, supra note 22, at 1364-83. 
1. The Relationship Between Compelled Access and Leveraging and Foreclosure Theory

First, a review of the findings and legislative history accompanying the 1992 Cable Act reveals that these access requirements were enacted out of the concern that a vertically integrated cable operator would be able to use its control over the retail level of production to harm competition in the wholesale market occupied by the cable networks and to bar the emergence of new competition at the retail level. ${ }^{281}$ Properly understood, such access requirements represent a version of leveraging and foreclosure theory and are thus subject to the same criticisms and caveats discussed above. Specifically, such regulations only make sense if the actor in question actually has monopoly power over the primary market and poses a real threat to the competitiveness of the secondary market. ${ }^{282}$ As detailed above, neither of these preconditions appears to hold with regards to cable television.

\section{The Administrability of Compelled Access}

Furthermore, scholars of competition policy generally agree that compelled access is, in many ways, quite problematic as a remedy. If regulators compel non-discriminatory access without putting any restrictions on the price charged, the monopolist will simply charge the full monopoly price. While such access would be beneficial to the monopolist's competitors, it provides no benefits to consumers, since the monopoly is left intact, and no improvements in price or output can be expected. ${ }^{283}$ Absent some regulation of the terms and conditions of access, compelled access represents something of an anomaly. As Professors Areeda and Hovenkamp note, the purpose of the competition policy "is not to force firms to share their monopolies, but to prevent monopolies from occurring or to break them down when they do occur."284

Thus, if an access remedy is to benefit consumers, it must necessarily include a requirement that the rates charged be reasonable. Any attempt at regulating rates would likely be extremely difficult to administer. Since the monopolist has already evinced a lack of willingness to deal with its competitor, the relationship is likely to be surrounded by disputes over the

281 S. REP. NO. 102-92, at 25-26 (1992), reprinted in 1992 U.S.C.C.A.N. 1133, 1158-59.

282 3A AREEDA \& HOVENKAMP, supra note 118 , ๆ $770 \mathrm{~b}$, at $167, \uparrow 772 \mathrm{c} 3$, at $192, \uparrow 773 \mathrm{~d}$, at 213; OWEN \& WILDMAN, supra note 169, at 236-40, 245; Posner, supra note 67, at 947 n.65; David J. Gerber, Note, Rethinking the Monopolist's Duty to Deal: A Legal and Economic Critique of the Doctrine of "Essential Facilities," 74 VA. L. REV. 1069, 1084 (1988). 208.

283 3A AREEDA \& HOVENKAMP, supra note 118, 1773, at 199; POSNER, supra note 69, at

284 3A AREEDA \& HOVENKAMP, supra note $118, \eta 771 \mathrm{~b}$, at 174. 
terms and conditions of the compelled access. As Professors Areeda and Hovenkamp have noted, once access is ordered,

[t]he plaintiff is likely to claim that the defendant's price for access to an essential facility (1) is so high as to be the equivalent of a continued refusal to deal, or (2) is unreasonable, or (3) creates a 'price squeeze' in that the defendant charges so much for access and so little for the product it sells in competition with the plaintiff that the latter cannot earn a reasonable profit. ${ }^{285}$

The disputes, moreover, will not be limited just to price. The parties are likely to disagree on non-price terms and conditions as well. ${ }^{286}$

As a result, the relationship will require significant ongoing supervision to a degree that resembles public utility regulation. ${ }^{287}$ It goes without saying that rate regulation in declining cost industries has been plagued by complicated valuation and second-best pricing problems that have bordered on insurmountable. Previous attempts at imposing rate regulation on cable television have largely been a failure, as the variability in the quality of cable programming has frustrated efforts to impose meaningful rate regulation. ${ }^{288}$

The FCC's history with policing access regimes provides ample reason to question whether it is institutionally capable of executing this charge. For example, leased access has been plagued by precisely the type of problems predicted by Areeda and Hovenkamp. Simply put, the regulatory regime went almost entirely unused, with the various parties disagreeing vehemently on the reason for the regime's failure. Firms that sought leased access complained that local cable operators demanded excessively high prices and failed to bargain in good faith, while the cable operators claimed that the lack of leased access reflected a lack of demand for it. ${ }^{289}$ Even more spectacular has been the inability of the FCC and the state public utility commissions to use access requirements to foster

285 Id. $\uparrow 774 \mathrm{e}$, at $227-28$; see also id. $\uparrow 765 \mathrm{c}$, at 103-04, $\uparrow 772$, at 197 .

286 Id. ๆ 773, at 216-17, ๆ 774e, at 227-28, ๆ 787, at 281-82; see also POSNER, supra note 69, at 211; POSNER \& EASTERBROOK, supra note 68, at 762-63; Keith N. Hylton, Economic Rents and Essential Facilities, 1991 BYU L. REV. 1243, 1283-84 (1991); Bruce M. Owen, Determining Optimal Access to Regulated Essential Facilities, 58 ANTITRUST L.J. 887, 890, 893 (1990); Gregory J. Werden, The Law and Economics of the Essential Facility Doctrine, 32 ST. LouIS U. L.J. 433, 460-61 (1987).

287 POSNER, supra note 69, at 211. It should be noted that such problems may be avoided if the owner of the bottleneck facility opens it to other customers. When that is the case, a regulatory authority can simply order non-discrimination in terms and conditions. This solution will not work, however, if the bottleneck owner devotes all available capacity to vertically affiliated entities.

288 See Thomas W. Hazlett \& MatThew L. Spitzer, Public Policy TOWARd Cable Television (1997); Gregory S. Crawford, The Impact of the Household Demand and Welfare, 31 RAND J. ECON. 422 (2000).

289 See Time Warner Entm't Co. v. FCC, 93 F.3d 957, 970 (D.C. Cir. 1996); 1990 Report on Cable Competition, supra note 207, at 5048, II 177; Donna M. Lampert, Cable Television: Does Leased Access Mean Least Access?, 44 FED. COMM. L.J. 245 (1992). 
competition in local telephone markets as mandated by the Telecommunications Act of 1996. The FCC's experience in policing other access regimes thus provides little reason to be optimistic that it will be able to manage the myriad problems associated with administering a regime of compelled access in this instance.

\section{Compelled Access and Dynamic Efficiency}

Compelled access regimes are thus extremely questionable from the standpoint of static efficiency, since it is far from clear whether they can deliver the requisite benefits in price and quantity needed to justify the enterprise. Even more profound is the impact that compelled access regimes have on dynamic efficiency. From the perspective of dynamic efficiency, the only viable way to solve the problems caused by monopoly bottlenecks is the appearance of a new entrant that directly competes with the bottleneck facility. Access regimes, however, may actually retard such entry.

Access dampens investment in two ways that harm consumers. First, it is now well recognized that resources are most likely to receive the appropriate level of conservation and investment if they are protected by well-defined property rights. As Garrett Hardin pointed out in his pathbreaking work on the "Tragedy of the Commons," resources that are in effect jointly owned tend to be overused and receive suboptimal levels of investment. ${ }^{290}$ Hardin's insights apply with equal force to compelled access regimes. Since any benefits gained from investments in capital or research must be shared with competitors, forcing a monopolist to share its resources reduces incentives to improve their facilities and pursue technological innovation. ${ }^{291}$

In addition, compelling access to an input also discourages other firms that need the input from entering into business alliances with potential alternative suppliers of the input. ${ }^{292}$ In effect, forcing a monopolist to share an input rescues other firms from having to supply the relevant input for themselves. ${ }^{293}$ For example, allowing cable networks to use access requirements to reach audiences may well be depriving DBS of the parties most likely to invest in helping it build out its facilities. In effect, compelled access cuts DBS off from its most natural strategic partners. As a consequence, it preempts the only solution to the bottleneck

290 Garrett Hardin, The Tragedy of the Commons, 162 SCIENCE 1243 (1968)

291 3A AREEDA \& HOVENKAMP, supra note 118, I773b2, at 203-04, I773b3, at 206-07, $9774 \mathrm{c}$, at $220-21$

292 Id. $\ 771 \mathrm{~b}$, at $174-76$, \773a, at 201; Hylton, supra note 286 , at 1261.

293 3A AREEDA \& HOVENKAMP, supra note 118, ๆ 773a, at 201. 
problem that is viable in the long run (i.e., the development of a viable alternative to the bottleneck facility).

Thus, access should not be compelled whenever the resource is available from another source, even if it is only available at significant cost and in the relatively long run. ${ }^{294}$ This is particularly true in technologically dynamic industries, in which the prospects of developing new ways either to circumvent or to compete directly with the bottleneck are the highest. ${ }^{295}$ The inevitable lag in adjusting regulation also raises the risk that regulations, such as access, that protect incumbents from new entry will continue to exist long after the justifications for enacting the regulation have long disappeared. ${ }^{296}$

\section{The Future of the Vertical Integration Provisions of the 1992 Cable Act}

It thus appears that the case for restricting vertical integration in the cable industry is quite weak. The relevant markets appear to be too unconcentrated and unprotected by barriers to entry to permit vertical integration to have significant anti-competitive effects. In addition, the cost structure and complementarities associated with television programming make it quite possible that vertical integration in the cable industry would yield significant efficiency benefits.

But perhaps the most important aspect of my analysis of the regulation of vertical integration in the cable industry revolves around the imposition of access remedies. As the foregoing discussion reveals, access remedies represent something of an embarrassment to competition policy. This is because access remedies simply demand that the monopoly power be shared, rather than broken up. As a result, access remedies are unlikely to promote static efficiency. The dynamic efficiency problems resulting from access requirements are, if anything, even more profound. By rescuing competing firms from having to develop alternative sources of supply, access remedies deprive those firms who are seeking to deploy technologies that would compete with the bottleneck of their natural strategic partners.

Despite these problems, however, the initial FCC and judicial decisions on these provisions evinced little inclination to challenge the

294 Id. $\lceil 773 \mathrm{~b} 2$, at 203-05, $7774 \mathrm{c}$, at $220, \uparrow 787 \mathrm{cl}$, at 290; David McGowan, Regulating Competition in the Information Age: Computer Software as an Essential Facility Under The Sherman Act, 18 HASTINGS COMM. \& ENT. L.J. 771, 804-06 (1996); John T. Soma et al., The Essential Facilities Doctrine in the Deregulated Telecommunications Industry, 13 BERKELEY TECH. L.J. 565, 594-96 (1998).

295 OWEN \& WILDMAN, supra note 169 , at 245 (1969).

296 Richard A. Posner, Natural Monopoly and Its Regulation, 21 STAN. L. REV. 548, 611-15 
current regulatory regime. There are at least some indications that this climate may be beginning to change. As noted earlier, ${ }^{297}$ a recent D.C. Circuit decision struck down the thresholds established by the FCC to implement the subscriber and channel occupancy provisions contained in the 1992 Cable Act. ${ }^{298}$ In addition, there are open proceedings before the FCC that could permit greater vertical integration in the cable industry, ${ }^{299}$ the prohibition on exclusive programming contracts is set to expire next year, ${ }^{300}$ and the FCC has commenced proceedings to evaluate whether the prohibition should be extended. ${ }^{301}$ It thus seems that the final chapter of this debate has yet to be written.

\section{Open Access to Cable Modem Systems and the New Economy Theories of Technological Change}

Although broadcast and cable television remain important sources of information and entertainment programming, it goes without saying that the most singular media-related development of the last several years has been the arrival of the Internet. In just five short years, the Internet has revolutionized communications in ways that until recently were inconceivable. The vast majority of U.S. households receive Internet service through an analog modem attached to a conventional telephone line. Now known as "narrowband" technology, conventional telephonebased connections permit theoretical connection speeds of 56.6 thousand bits per second ("kbps"), with actual connection speeds typically falling in the range of $30-40 \mathrm{kbps} .{ }^{302}$ Under the typical narrowband setup, an Internet user uses a conventional telephone line, provided by a local telephone company such as Verizon, SBC, Qwest, or BellSouth, to connect to any one of a large number of Internet service providers ("ISPs"), such as America Online, MSN or Earthlink. The ISP in turn provides access to the content and other services residing on a global network of computers interconnected by what are known as Internet "backbones." Since local telephone companies allow any ISP with a local or toll-free telephone number to operate on their system, narrowband consumers typically face a wide range of choices in ISPs.

297 See supra notes 212-213 and accompanying text.

298 Time Wamer Entm't Co. v. FCC, 240 F.3d 1126, $1130-39$ (D.C. Cir.), cert. denied, 122 S. Ct. 644 (2001)

299 Implementation of Section 11 of the Cable Television Consumer Protection and Competition Act of 1992, 16 F.C.C.R. 17,312 (2001) (Further Notice of Proposed Rulemaking).

30047 U.S.C. $\$ 548(\mathrm{c})(5)(1994)$.

301 Implementation of the Cable Television Consumer Protection and Competition Act of 1992, 16 F.C.C.R. 19,074 (2001) (Notice of Proposed Rulemaking).

302 Although most conventional modems are technically capable of carrying up to $56.6 \mathrm{kbps}$, the physical characteristics of the telephone lines that those modems use to connect to the Internet limit speeds to the $30-40$ kbps range. 
More and more, however, U.S. consumers have been turning to "broadband" technologies that allow subscribers to achieve actual speeds in excess of one million bits per second $(1 \mathrm{Mbps}){ }^{303}$ Although several different broadband technologies exist, cable modem systems, which provide broadband services via coaxial cables originally designed to carry television programming, have taken the early lead, having signed up well over five million households. Unlike narrowband systems, however, broadband providers typically require their customers to use a designated ISP.

The emergence of cable modem systems has in turn raised serious questions about whether and how this new industry should be regulated. The most salient regulatory question has centered on whether the FCC should require cable modem system operators to offer consumers a broader range of ISP choices. The ensuing debate over "open access" 304 has largely centered on the classic type of vertical integration arguments discussed above. For example, Professor James Speta has led a group of scholars challenging the notion that vertical integration or exclusive dealing arrangements with ISPs can enable cable modem systems to increase monopoly profits. ${ }^{305}$ On the other side of the equation, a group of distinguished scholars have applied the tools of game theory, network economics, and innovation dynamics to propose new theories about how such vertical integration could harm competition. ${ }^{306}$

This Part will analyze the various economic arguments surrounding open access, following the same organizational pattern as the previous discussions of broadcast and cable regulation. Section A will begin by reviewing the structure of the cable modem industry, the current regulatory regime governing that industry, as well as the economic arguments advanced in support of that regime. Section B will use the basic economic model of vertical integration developed above to conduct a static efficiency analysis that evaluates the extent to which vertical integration is likely to threaten competition in the cable modem industry. I conclude that

303 Most DSL and cable modem users can expect speed somewhere in the neighborhood of 1.5 Mbps. Theoretical speeds are much higher. See Speta, Handicapping, supra note 21, at 52, 56 (noting that ADSL and cable modems have a theoretical maximum of $10 \mathrm{Mbps}$ and $27 \mathrm{Mbps}$ respectively).

304 This particular term is contested. While proponents of this particular regulatory reform call it "open access," opponents refer to it as "forced access." See AT\&T-MediaOne Merger, supra note 5 , at 9866, ๆ 114.

305 Speta, Vertical Dimension, supra note 21, at 996; see also Benjamin, supra note 26, at 297-98; John E. Lopatka \& William H. Page, Internet Regulation and Consumer Welfare: Innovation, Speculation, and Cable Bundling, 52 HASTINGS L.J. 891, 907-13 (2001); Phil Weiser, Paradigm Changes in Telecommunications Regulation, 71 U. CoLO. L. REV. 819, 834 (2000).

306 See Chen, supra note 13; Hausman et al., supra note 13; Lemley \& Lessig, supra note 16; Rubinfeld \& Singer, supra note 13; Kevin Werbach, A Layered Model for Internet Privacy, 1 CoLo. J. ON TElECOMM. \& HIGH TECH. L. (forthcoming Spr. 2002), available at http://www.edventure.com' conversation/article.cfm?Counter $=2414930$. 
the structure of the broadband industry renders it unlikely that such combinations will pose any significant anti-competitive threat and that in fact such combinations might well lead to significant transaction cost efficiencies.

Section $\mathrm{C}$ will then apply the framework developed in the discussion of cable access requirements to evaluate open access in terms of dynamic efficiency. I conclude that imposing open access would retard the deployment of cable modem services by rescuing competing ISPs from having to invest in building out alternative means for reaching high-speed broadband customers. In so doing, open access would deprive companies attempting to deploy alternative broadband technologies, such as DSL and satellite broadband services, of their natural strategic partners.

Finally, Section D will take on the New Economy arguments advanced by Professors Mark Lemley, Lawrence Lessig, and others contending that open access is required in order to maintain the uniform, "end-to-end" architecture upon which innovation on the Internet depends. My review of the economic literature suggests that the relationship between open access and innovation is far more complex than these scholars suggest. In fact, an analysis of the formal models reveals that requiring all broadband providers to adhere to a uniform set of protocols may discourage, rather than promote, innovation. It thus appears that imposing vertical structural restrictions on cable modem services would be just as unjustified as the imposition of similar restrictions to broadcasting and to cable television.

\section{A. The Cable Modem Industry and the Open Access Debate}

\section{The Structure of the Cable Modem Industry}

Despite claims that the Internet is fundamentally different from other media, the vertical structure of the narrowband and broadband markets are remarkably similar to other markets. As was the case with broadcasting and cable, it is quite easy to map the high-speed broadband industry onto the three-stage chain of production and distribution consisting of manufacturing, wholesaling, and retailing that typifies most conventional industries. ${ }^{307}$

The manufacturing stage consists of those companies that generate the webpage content and Internet-based services that end users will actually consume. The wholesale stage is occupied by the ISPs, which, in the words of two noted open access advocates, add value through their

307 For application of a similar taxonomy, see Lopatka \& Page, supra note 21, at 897. 
"unique aggregation and presentation of content that allowed for easy consumption by end users." 308 As was the case with respect to broadcast and cable television, firms often operate at both the manufacturing and wholesale stage by controlling proprietary content and providing services such as chat rooms and instant messaging. ${ }^{309}$ Finally, cable modem providers and other companies who deliver the content and service packages assembled by the ISPs to end customers occupy the retail stage. I will refer to this stage of production as broadband transport services.

\section{Regulatory Consideration of Open Access}

Questions about vertical integration in the cable modem industry first arose during the FCC's review of AT\&T's proposed acquisitions of TCI and MediaOne. In those proceedings, a number of parties argued that allowing AT\&T to bring both physical transmission and ISP services under the same corporate umbrella would allow AT\&T to use its control over cable to harm competition in the market for ISPs. As a result, these parties asked the FCC to impose an "open access" requirement, which would have forced AT\&T to allow independent ISPs to interconnect with AT\&T's cable modem service network on non-discriminatory terms. ${ }^{310}$

Consistent with its longstanding policy of non-regulation of computer-based services, ${ }^{311}$ the FCC refused to impose open access as a merger condition in either case. ${ }^{312}$ In so ruling, the FCC rejected arguments that such vertical linkages threatened competition. ${ }^{313}$ On the contrary, the FCC concluded that refusing to impose open access would be more effective in encouraging the deployment of high-speed broadband services. ${ }^{314}$ To the extent that such problems existed, they were primarily horizontal rather than vertical and would remain regardless of whether the mergers went through. ${ }^{315}$

Since cable operators are subject to municipal as well as federal regulation, open access advocates pressed their arguments before municipal regulators. Some of these municipal authorities were more accommodating than the FCC, either mandating open access by municipal ordinance $^{316}$ or requiring it as a condition for the transfer of a license

308 Rubinfeld \& Singer, supra note 13 , at 634.

309 See AT\&T-TCI Merger, supra note 6 , at $3193, \uparrow 65$.

310 Id. at 3197-98, T75; AT\&T-MediaOne Merger, supra note 5, at 9866, ๆ7 114-15.

311 See, e.g., OXMAN, supra note 7, at 8-12.

312 AT\&T-TCI Merger, supra note 6, at 3205-08, 17 92-96; AT\&T-MediaOne Merger, supra note 5 , at $9872-73, \Upsilon 127$.

313 AT\&T-MediaOne Merger, supra note 5, at 9872-73, ๆ 127.

314 AT\&T-TCI Merger, supra note 6, at 3206, $\uparrow 94,3229-32$, $\uparrow \uparrow 147-48$.

315 Id. at $3207, \uparrow 96$.

316 See Comcast Cablevision of Broward County, Inc. v. Broward County, 124 F. Supp. 2d 685, 686-87 (S.D. Fla. 2000). 
needed to complete AT\&T's acquisitions of TCI and MediaOne. ${ }^{317}$ Although this municipal-based strategy was soon cut short by a series of judicial decisions holding that the FCC had exclusive jurisdiction over the issue, ${ }^{318}$ these early successes represented the first acceptance of open access as a policy matter.

It was not until the FCC's consideration of the AOL-Time Warner merger that the open access advocates were able to garner sustainable victories. On January 11, 2001, within two years of rejecting calls for open access in AT\&T's acquisitions of TCI and MediaOne, the FCC abruptly reversed course and endorsed the FTC's requirement that Time Warner and America Online negotiate open access with at least three unaffiliated ISPs as a condition to their merger. ${ }^{319}$ It is expected that the FCC will offer more definitive guidance after it completes an ongoing Notice of Inquiry on the issue. ${ }^{320}$

\section{The Economic Theory Underlying the Open Access Debate}

As noted earlier, open access advocates have based their arguments on a wide range of economic theories. The first set of theories should be quite familiar by now. The first theory argues that vertical integration between cable modem providers and ISPs enables the combined entity to harm competition in the market for ISPs by discriminating against unaffiliated content. ${ }^{321}$ This corresponds to the traditional concern about leverage. The second theory focuses on the danger that cable modem providers will use their control over proprietary content to obstruct the emergence of DSL and other broadband alternatives. ${ }^{322}$ This strategy corresponds to the traditional concerns about foreclosure.

The other theories draw on a more diverse range of economic concepts. For example, Professors Lemley and Lessig argue that innovation in Internet-based technologies depends upon the preservation of interoperability ${ }^{323}$ Other scholars have employed such new economic tools as game theory ${ }^{324}$ and network economics ${ }^{325}$ to support their calls for open

317 See MediaOne Group, Inc. v. County of Henrico, 257 F.3d 356, 360 (4th Cir. 2001); AT\& T Corp. v. City of Portland, 216 F.3d 871, 875 (9th Cir. 2000).

318 See MediaOne, 257 F.3d at 360;AT\&T, 216 F.3d at 875.

319 AOL-Time Warner Merger, supra note 10, at 6568-69, $\$ 57$.

320 See Inquiry Concerning High-Speed Access to the Intemet Over Cable and Other Facilities, 15 F.C.C.R. 19,287 (2000) (Notice of Inquiry). Open access is also likely to emerge as in issue in obtaining regulatory approval of Comcast's acquisition of AT\&T's cable properties that was announced as this Article was going to press. See Yochai J. Dreazen, AT\&T, Comcast Likely to Get Regulators' Nod, WALL ST. J., Dec. 21, 2001, at A3.

321 See Rubinfeld \& Singer, supra note 13, at 636 (calling this strategy "content discrimination").

322 See id. (calling this strategy "conduit discrimination").

323 Lemley \& Lessig, supra note 16, at 930-46.

324 See Rubinfeld \& Singer, supra note 13. 
access. After applying the analytical structure developed in the foregoing discussions to the cable modem industry, I will proceed to evaluate these New Economy theories.

\section{B. Structural Market Conditions}

As the framework developed earlier reveals, in order to succeed, foreclosure and leveraging strategies depend on the existence of market power in the primary market (broadband transport) as well as a real threat of anti-competitive effects in the secondary market (ISPs). A review of the current deployment of broadband services renders these claims untenable on their face. The broadband transport market is too unconcentrated and the ISP market insufficiently protected by barriers to entry to allow vertical integration to have significant anti-competitive effects. In addition, it is possible to identify a number of efficiency justifications for such integration. Thus, under the conventional economic analysis, it is quite likely that imposing open access would actually harm, rather than benefit, competition.

\section{Concentration in the Market for Broadband Transport}

The first issue in determining whether vertical integration can harm competition in the cable modem industry is concentration in the primary market. Open access advocates have generally concluded without much analysis that such power exists. In so concluding, they have fallen into two misconceptions, one resulting from confusion about the proper definition of the relevant market, and the other stemming from treating the cable modem industry as a unified whole.

Regarding the first misconception, some analyses have argued that the fact that many communities have only one cable system inescapably implies that cable modem providers have monopoly power in the market for broadband transport services. ${ }^{326}$ The problem with this approach is that it focuses on the wrong market. It focuses on the local market in which end users meet their broadband transport provider. As I pointed out in the discussion regarding vertical integration in the cable television industry, if this is the appropriate market, then any restrictions on vertical integration would be largely irrelevant, since even complete vertical disintegration in

325 See Hausman et al., supra note 13, at 161-64

326 Lemley \& Lessig, supra note 16, at 965 (asserting that cable modem providers have market power in the market for broadband transport because "[c]able companies do have monopolies over cable wires in their local service area by government fiat"). 
the industry would not change the fact that end users would only have limited options in broadband transport service providers. ${ }^{327}$

The key to clearing up this misconception is to realize that open access is not designed to mitigate the exercise of monopoly power in the local markets in which retailers meet end consumers. Rather, its purpose is to protect competition in the national market in which broadband transport providers obtain content from the ISPs. Thus, the proper question is not whether the broadband transport provider has monopoly control over broadband users in any particular city, but rather whether that provider has market power in the national market for obtaining broadband content. The fact that a particular cable modem operator may have a local monopoly in a particular city is irrelevant so long as each network has access to a sufficient number of users in other cities around the U.S.

The second misconception is represented by the argument that cable modem providers clearly have market power because cable modem systems account for approximately seventy percent of the broadband market. ${ }^{328}$ This leads Daniel Rubinfeld and Hal Singer to declare that the HHI for residential broadband access to be $5673 .{ }^{329}$ The flaw in this argument is that, in addition to treating the relevant markets as local in scope, it treats the entire cable modem industry as if it were a single company. Although the cable modem industry may control seventy percent of the market, that industry is made up of a number of smaller players, none of whom have anything approaching a seventy percent share. It is thus impossible to determine the degree of concentration simply by looking at the overall penetration of the cable modem industry. In order to understand the appropriate degree of concentration in the relevant market, it is necessary to calculate HHIs on a company-by-company basis.

Turning now to the HHI calculation, there can be no question that cable modem services have taken the early lead in the broadband race. ${ }^{330}$ Cable modem services are now available in nearly sixty percent of all U.S. households, ${ }^{331}$ and cable modem providers signed up more than 5.4 million subscribers as of June $30,2001 .{ }^{332}$ Even if we were to define cable modem

327 See supra Subsections II.B.1, II.B.5.b.

328 Hausman et al., supra note 13, at 155; Lemley \& Lessig, supra note 16, at 952.

329 Rubinfeld \& Singer, supra note 13, at 649.

330 After initially declining to decide the issue, AT\&T-TCI Merger, supra note 6 , at 3205 , $\uparrow$ 92; AT\&T-MediaOne Merger, supra note 5, at 9866, \116, the FCC squarely concluded that narrowband and broadband constitute separate markets. AOL-Time Warner Merger, supra note 10, at 78-88, If 69-73. A recent econometric study indicates that the price of narrowband service does not constrain the price of broadband access. Jerry A. Hausman et al., Cable Modems and DSL: Broadband Internet Access for Residential Customers, 91 AM. ECON. REV. 302, 303-04 (2001).

331 National Cable \& Telecommunications Association, Industry Statistics, at http://www.ncta.com/industry_overview/indStat.cfm?indOverviewID=2.

332 Residential Broadband Customer Count Tops 10 Million, CABLE DATACOM NEws (Sept. 1, 2001), at http://www.cabledatacomnews.com/sep01/sep01-1.html. 
systems as a product market unto itself, however, it is far from clear that it is sufficiently unconcentrated to support leveraging or foreclosure as anticompetitive strategies. ${ }^{333}$

Table VI. Total High-Speed Lines as of June 2001
(Over 200 kbps in at least one direction)

\begin{tabular}{lrrrrr}
\hline & & & & \multicolumn{2}{c}{ Percent Change } \\
& & & & June 2000- & Dec. 2000- \\
Technology & June 2000 & Dec. 2000 & June 2001 & Dec. 2000 & June 2001 \\
\hline & & & & & \\
Cable modems & $2,284,491$ & $3,582,874$ & $5,184,141$ & $57 \%$ & $43 \%$ \\
DSL & 951,583 & $1,977,101$ & $2,693,834$ & $108 \%$ & $36 \%$ \\
Other & $1,131,360$ & $1,509,899$ & $1,738,366$ & $33 \%$ & $15 \%$ \\
& & & & & \\
Total & $4,367,434$ & $7,069,874$ & $9,616,341$ & $62 \%$ & $36 \%$ \\
\hline
\end{tabular}

Source: High-Speed Services Report, supra note 335, at 6 tbl.1.

But as noted earlier, proper calculation of HHIs requires consideration of substitutes for cable modem service. The evidence suggests that DSL has become an effective competitor to cable modem systems, capturing more than three million subscribers ${ }^{334}$ and growing at rates comparable to that of cable modem services. ${ }^{335}$ Market research indicates that some subscribers prefer the fact that DSL is not subject to the privacy and congestion problems that afflict cable modem systems. ${ }^{336}$ Although it was once true that DSL was only available in households within roughly 3.5 miles of a large telephone facility known as a central office switch, ${ }^{337}$ recent technological developments have made it possible to extend DSL's reach through the use of "remote terminals" and "loop extenders. ${ }^{, 338}$ In addition, DSL providers have lowered adoption costs by offering substantial promotional discounts and free DSL modems. ${ }^{339}$

333 A calculation based on the available data reveals an HHI of 1720. See Industry Statistics, supra note 331 .

334 Id.

335 Federal COMmunications COMmission, High-SPEED SERVICES FOR INTERNET ACCESS: SUBSCRIBERSHIP AS OF JUNE 30, 2001, at 5 (Feb. 2002), at http://www.fcc.gov/Bureaus/ Common_Carrier/Reports/FCC-State_Link/IAD/hspd0202.pdf [hereinafter High-Speed Services Report].

336 William P. Rogerson, The Regulation of Broadband Telecommunications, the Principle of Regulating Narrowly Defined Input Bottlenecks, and Incentives for Investment and Innovation, 2000 U. CHI. LEGAL. F. 119, 147 n.13.

337 Lemley \& Lessig, supra note 16 , at $2,37$.

338 See Donny Jackson, Shifting Gears: DSL Vendors Target ILECs with Retooled Products and New Standards, TELEPHONY, July 2, 2001, at 60; Michael Martin, Vendors Focus on Bringing 
When DSL numbers are combined with cable modem numbers, it becomes clear that concentration levels in the market for high-speed

Table VII. Concentration in the Market for Broadband Transport Services as of June 30, 2001

\begin{tabular}{lrrr}
\hline Provider & $\begin{array}{c}\text { Subscribers } \\
\text { (thousands) }\end{array}$ & Share & HHI \\
\hline Time Warner Cable & 1,409 & $16 \%$ & 258 \\
AT\&T Broadband & 1,346 & $15 \%$ & 235 \\
SBC Communications & 1,037 & $12 \%$ & 139 \\
Verizon Communications & 840 & $10 \%$ & 92 \\
Cox Communications & 668 & $8 \%$ & 59 \\
Comcast Cable Communications & 676 & $8 \%$ & 58 \\
Charter Communications & 419 & $5 \%$ & 23 \\
BellSouth Corp. & 381 & $4 \%$ & 19 \\
Cablevision Systems Corp. & 368 & $4 \%$ & 18 \\
Qwest Communications & 360 & $4 \%$ & 17 \\
Covad Communications & 333 & $4 \%$ & 14 \\
Adelphia Communications & 253 & $3 \%$ & 8 \\
RCN Corp. & 95 & $1 \%$ & 1 \\
Rhythms NetConnections & 83 & $1 \%$ & 1 \\
Insight Communications & 82 & $1 \%$ & 1 \\
Mediacom LLC & 80 & $1 \%$ & 1 \\
Broadwing & 51 & $1 \%$ & 0 \\
Other cable modem & 50 & $1 \%$ & 0 \\
Other DSL & 249 & $3 \%$ & 1 \\
& & & \\
Total & 8,780 & $100 \%$ & 944 \\
\hline
\end{tabular}

Source: Residential Broadband Customer Count Tops 10 Million, CABLE DATACOM NEWS (Sept. 1, 2001), at http://www.cabledatacomnews.com/sep01/sep01-1.html.

DSL to Non-Metro Users, NETWORK WORLD EDGE, June 11, 2001, at 28; Vince Vittore, Making DSL Go for the Long Run, TELEPHONY, Dec. 11, 2000.

339 See, e.g., John Cook, DSL Providers Jump at Chance to Pick Up New Subscribers, Seattle Post-InTElligenCER, Dec. 5, 2001, at Cl; Microsoft, Major Phone Firms in DSL Deal, SAN DiEgo UNION-TRIB., Oct. 16, 2001, at C10. 
broadband fall far below the levels that traditionally have led to antitrust concerns. ${ }^{340}$

Furthermore, when a market is undergoing explosive growth, it is the projected levels of concentration rather than current levels of concentration that matter more. The FCC's own projections indicate that the competition between DSL and cable modem will only intensify over the next several years. While the FCC estimates that by 2004 cable modem service will reach eighty-four percent of U.S. households and 15.2 million subscribers, it also estimates that, by that time, DSL will approach parity with cable modems, reaching eighty percent of U.S. households and capturing a total subscribership of 13 million. ${ }^{341}$

\section{Table VIII. Projected Subscribership for Broadband Transport Services}

\begin{tabular}{|c|c|c|c|c|}
\hline \multirow{3}{*}{$\begin{array}{l}\text { Broadband } \\
\text { Technology }\end{array}$} & \multirow{2}{*}{\multicolumn{2}{|c|}{$\begin{array}{c}\text { As of Dec. } 31,2000 \\
\text { Subscribers (millions) }\end{array}$}} & \multicolumn{2}{|c|}{ Projected Dec. 31, 2004} \\
\hline & & & \multirow{2}{*}{$\begin{array}{c}\text { Subscribers } \\
\text { (millions) }\end{array}$} & \multirow{2}{*}{$\begin{array}{l}\text { National } \\
\text { Coverage }\end{array}$} \\
\hline & Projected & Actual & & \\
\hline Cable modems & 3.2 & 3.6 & 15.2 & $84 \%$ \\
\hline DSL & 2.0 & 2.0 & 13.0 & $80 \%$ \\
\hline Wireless & $\mathrm{n} / \mathrm{a}$ & $\mathrm{n} / \mathrm{a}$ & 3.0 to 4.4 & $34 \%$ \\
\hline Satellite & $\mathrm{n} / \mathrm{a}$ & 0.06 & 1.2 to 4.6 & $100 \%$ \\
\hline
\end{tabular}

Sources: Second Advanced Services Report, supra note 4, at 20,984-86, 20,988, 20,990, 9 Tा 187, 189, 191, 196-197, 202; High-Speed Services Report, supra note 335, at 6 tbl.1.

In addition, there are two satellite broadband providers currently operating: DirecWay and Starband. Although the service is not yet quite comparable to that provided by DSL and cable modems, ${ }^{342}$ they do possess one advantage: they are already available on a nationwide basis and are

340 As noted earlier, AT\&T announced that it was selling its cable holdings to Comcast as this Article was going to press. See Solomon \& Frank, supra note 229. Consummation of this deal, upon regulatory approval, would not materially affect my conclusions. The combination of AT\&T and Comcast would create a single entity with twenty-three percent of the broadband transport market, with a resulting $\mathrm{HHI}$ contribution of 526 , an increase of 233 points over the HHI contributions of AT\&T and Comcast when treated as separate entities. Total HHI would only increase to 1178 , still well below the 1800 level identified by the Vertical Merger Guidelines as the threshold for anticompetitive concern.

341 Second Advanced Services Report, supra note 4, at 20,984-88, ๆ 187, ๆ 189, ๆ 191 , ๆ 195. These estimates contradict the suggestion that DSL is unlikely to exert competitive pressure on cable modem systems over relevant time horizons. See Hausman et al., supra note 13, at 149-51.

342 Satellite broadband is somewhat slower than DSL and cable modem service, achieving peak download speeds of 400-500 kbps and peak upload speeds of 128-150 kbps. Users also need to pay a significant up-front fee for hardware and installation. In addition, at seventy dollars per month, it is priced somewhat higher than DSL and cable modem service. John Yaukey, Satellite Broadband, TENNESSEAN, Sept. 18, 2001, at 4E. 
thus able to reach rural areas that are likely to remain unserved by either cable modems or DSL. ${ }^{343}$ The FCC reports projected subscription rates of between 1.2 to 4.6 million, primarily concentrated outside urban areas. ${ }^{344}$

Other companies have begun to invest in a microwave technology known as multipoint distribution systems ("MDS") that was originally intended to provide television programming in competition with local cable systems and convert it into providing high-speed broadband services. ${ }^{345}$ Estimates suggest that these fixed wireless services should reach thirty-four percent of U.S. households and obtain somewhere between 3.0 and 4.4 million subscribers in $2004 .{ }^{346}$

Furthermore, we are just seeing the beginnings of the deployment of third-generation (" $3 G$ ") wireless devices, which promise to provide yet another platform for high-speed broadband access on a mobile basis. Unlike current wireless Internet connections, which can only achieve speeds between 9.6 to $28 \mathrm{kbps}, 3 \mathrm{G}$ devices offer the promise of delivering data at speeds comparable to that offered by cable modem services and DSL. ${ }^{347}$

This is not to say that broadband deployment has gone smoothly. Each of the major broadband technologies has confronted its share of problems. ${ }^{348}$ Indeed, it remains quite possible that some unforeseen development may force one of the contenders for broadband dominance to fall by the wayside. For the purposes of this Article, it suffices to observe that the market for broadband transport services as it is currently constituted is insufficiently concentrated for vertical integration to raise any significant anti-competitive concerns. With regard to the future broadband market, regulators must take special care not to exert undue influence on the final technological outcome. The indeterminacy about the final market position of the various platforms only serves to underscore the risks attending any regulatory intervention at this point in the industry's development.

343 Second Advanced Services Report, supra note 4, at 20,937, \56, 20,990, \202.

344 Id. at $20,990, \Upsilon 202$.

345 This includes both multichannel multipoint distribution services ("MMDS") and local multipoint distribution services ("LMDS"). See id. at 20,988-89, ๆ7 197-99.

346 Id. at 20,988, ๆ 197.

347 See James H. Johnston, The Next New Thing: Third Generation Wireless, LEGAL Times, Jan. 18,2001 , at 25 (noting that $3 \mathrm{G}$ systems will operate at up to $384 \mathrm{kbps}$ if the user is walking and 2 Mbps if the user is stationary).

348 As noted earlier, DSL providers have been subject to a significantly higher degree of regulation than cable modem providers. In addition, DSL deployment has been plagued by service problems and a number of high-profile bankruptcies. See Dissatisfied Customers Sue Verizon over DSL Installation, L.A. TiMES, Jan. 29, 2001, at C5; Kalpana Srinivasan, Cable Net Providers Taking the Lead, Hous. CHRON., June 12,2001, at 4. At the same time, the collapse of Excite@Home represented a significant setback for the cable modem industry. See Mylene Mangalindan, Excite@Home's Decision to Shut Down Carries Bitter Fallout for Investors, WALL ST. J., Dec. 6, 2001, at B8. 


\section{Concentration and Barriers to Entry into the Market for ISPs}

In addition, the structure of the ISP market makes it extremely unlikely that cable modem providers pose any realistic threat to competition. As the FCC has recognized, the market for ISPs has historically been quite competitive ${ }^{349}$ and the low degree of concentration in the broadband market discussed makes it all but impossible for any cable modem service provider to use vertical integration to foreclose other ISPs from obtaining the high-speed broadband access they need.

In addition, the current wave of explosive growth further lowers the barriers to entry faced by ISPs. Currently, approximately one-third of all U.S. households are on-line, with the vast majority (ninety-two percent) obtaining their services via narrowband connections. ${ }^{350}$ The FCC projects that the number of on-line households will double over the next three years, with almost all of the new growth representing new broadband users. ${ }^{351}$ Even if existing users were for some reason unlikely to switch from their current services, the availability of such a large number of new customers should be more than sufficient to render most foreclosure strategies pointless. ${ }^{352}$

349 AT\&T-TCI Merger, supra note 6, at 3206, ๆ 93.

350 Second Advanced Services Report, supra note 4, at 20,983, $\uparrow 186$.

351 Id.

352 It should also be noted that the FCC has consistently maintained that all DSL technologies constitute network elements that the incumbent local telephony companies (called incumbent local exchange carriers or ILECs) must offer to their competitors on an unbundled basis. Deployment of Wireless Servs. Offering Advanced Telecomms. Capability, 15 F.C.C.R. 385 (1999) (Order on Remand) (affirming that ILECs are subject to the obligations imposed by Section 251 of the Communications Act in connection with the offering of advanced services); Deployment of Wireline Servs. Offering Advanced Telecomms. Capability, 13 F.C.C.R. 24,012, 24,031-34, fi 34-44 (1998) (Memorandum Opinion and Order, and Notice of Proposed Rulemaking). Given the easy access to DSL, it is hard to see how vertical integration by a cable modem provider could serve to restrict entry.

I have serious doubts as to whether compelling access to DSL systems represents good policy. There seems little justification for compelling access to services that are not natural monopolies and, as noted above, the relevant markets are insufficiently concentrated for vertical integration to pose a threat to competition. In addition, by subjecting the different broadband transport to different regulatory regimes, the FCC risks being responsible for picking the technological winner. A recent D.C. Circuit decision recently overturned a recent FCC order on unbundled access to DSL systems and remanded it for further proceeding. See WorldCom, Inc. v. FCC, 246 F.3d 690 (D.C. Cir. 2001) (vacating and remanding the FCC's classification of DSL-based advanced services as "telephone exchange services" or "exchange access"). Recent regulatory proposals suggest that the FCC may be ready to release DSL from its access obligations. See Appropriate Framework for Broadband Access to the Intemet over Wireline Facilities, FCC 02-42 (F.C.C. rel. Feb. 15, 2002) (Notice of Proposed Rulemaking); Review of Regulatory Requirements for Incumbent LEC Broadband Telecomms. Servs., 16 F.C.C.R. 22,745 (2001) (Notice of Proposed Rulemaking); Review of Section 251 Unbundling Obligations of Incumbent Local Exch. Carriers, 16 F.C.C.R. 22,781 (2001) (Notice of Proposed Rulemaking). 
3. Potential Efficiencies from Combining Cable Modem and ISP Services

The final step in the conventional analysis is to evaluate whether vertical integration is likely to yield significant efficiencies. An analysis of the cable modem industry reveals that many of the potential efficiencies identified with respect to broadcast and cable television may well exist with respect to cable modem service as well.

\section{a. Elimination of Static Transaction Costs and Double Marginalization}

Importance of Guaranteed Distribution. Like all media products, the creation of broadband content necessarily requires significant, up-front, first-copy costs that are large in comparison to the marginal costs of distribution, which tend to be negligible. This cost structure creates a natural tendency for broadband content to seek widescale distribution, since economic efficiency increases as the fixed cost investment is amortized over an increasingly large volume of users. ${ }^{353}$

As a result, the equilibrium level of distribution in the broadband market is likely to be fairly widescale. It is quite logical then for ISPs and other content providers either to enter into contracts that guarantee them access to all of a cable modem system's customers or to integrate vertically with cable modem systems. This is not to say that content providers unable to secure universal distribution will be barred from entering, since it is clear that the minimum viable scale is small relative to the national market. My point is that the erection of artificial regulatory barriers preventing ISPs from entering into such arrangements with cable modem systems can increase the risks associated with creating new broadband content, a development which would correspondingly depress investment in content below optimal levels, as well as retard or deter the entry of new content providers.

The Problem of Double Marginalization. As noted earlier, vertical integration can enhance efficiency by allowing the integrated firm to transfer inputs at marginal cost. ${ }^{354}$ Once broadband content has been created, the marginal cost of duplicating and distributing it to additional users is negligible. As a result, if the transaction between the broadband content provider and the broadband transport service provider occurs across a firm boundary, it is inevitable that the content provider will charge the transport provider a positive price that exceeds marginal cost,

353 Rubinfeld \& Singer, supra note 13 , at $642-44$

354 See supra notes $84-88$ and accompanying text 
which, in turn, will reduce allocative efficiency. Vertical integration would allow the combined entity to ignore the appropriate transfer price and instead focus solely on the price charged for the final delivery of the service. Doing so should allow the entity to eliminate the markup charged by the content provider and price the final good closer to the welfaremaximizing level.

Caching. Open access would potentially raise a number of technical problems as well. Modern ISPs minimize off-network traffic by "caching," a process in which the ISP gathers information from popular websites and stores it at its headend. Thus, the ISP can serve all of its customers who are interested in accessing a popular site with a single query to that site's server. Once the ISP has stored that content at its headend, all interested subscribers can access the content without having to tie up resources outside of the ISP's proprietary system. ${ }^{355}$

Like all systems involving fixed costs, however, caching systems must spread their costs over as large a number of subscribers as possible in order to be economically viable. If other ISPs are allowed access to cable modem systems, each ISP's caching costs will be spread across fewer subscribers, a result which would raise the cost of providing high-quality service. Worse yet, the unaffiliated ISPs would either have to create caching systems of their own, a result which would duplicate costs and waste resources, or would simply provide consumers with a lower quality product. ${ }^{356}$ Neither alternative seems particularly attractive.

Economies of Scope. Allowing ISPs to integrate with cable modem systems would also enable broadband providers to take advantage of the available economies of scope. For example, requiring open access would prevent cable modem systems from realizing the transaction cost economies associated with marketing, billing, and servicing both products together. Joint provision can be particularly important when the overall performance of the final product depends upon inputs provided by two different companies and when consumers have trouble distinguishing which of the two companies is responsible for any performance inadequacies. In such cases, the two companies may simply blame each other for the system's poor performance. Customers that experience unsatisfactory performance with an emerging technology may simply choose to drop the product without attempting to identify the cause of the poor performance. ${ }^{357}$ In such cases, allowing a single company to provide

355 Hausman et al., supra note 13 , at 160.

356 See Bruce M. Owen \& Gregory L. Rosston, Cable Modems, Access and Investment Incentives 18-19 (Dec. 1998) (unpublished manuscript), available at http:/gullfoss2.fcc.gov/prod/ecfs/ retrieve.cgi?native_or_pdf-pdf\&id_document $=6006242167$.

357 See J. Gregory Sidak, An Antitrust Rule for Software Integration, 18 YALE J. ON REG. 1, 9-10 (2001). 
both complementary services better enables it to ensure the overall performance of the system. As the Supreme Court has implicitly recognized in an early cable television case, such concerns are particularly important in the case of new products, such as cable modem service, since an emerging industry's "short and long-term well-being depend[s] on the success of the first systems sold." 358

Such economies of scope appear to exist in the cable modem industry. As experience in other telecommunications sectors has revealed, joint marketing of services can prove to be an essential means of competition. Absent some ability to guarantee a quality end-to-end product, cable modem systems will place less promotional efforts behind their products and risk alienating customers who have unsatisfactory experiences. ${ }^{359}$

Finally, the overall speed performance is a product of both the characteristics of the cable modem system, but also the server technology employed by the ISP. In addition, system performance is also determined in no small part by the degree of compatibility between the cable modem system and the ISP. ${ }^{360}$ A customer receiving unsatisfactory service may often be unable to discern whether the problem lies with the cable modem system or with the ISP. In a fledgling industry like the cable modem industry, the user may well form his or her opinion without determining the true cause of the poor performance. Integrating cable modem systems and ISPs simplifies the coordination of decisions in ways that avoid such problems and ensure end-to-end quality. It also allows customers to call a single service desk that is responsible for solving all of their problems.

\section{b. Elimination of Strategic Behavior}

Hold Up. The presence of the large upfront fixed costs discussed above also leaves both cable modem and content providers vulnerable to being held up. Like other creators of media content, broadband content providers must make significant up-front investments in their content. They will not do so unless they can expect to recover those fixed costs later. Once the content is created, however, content providers are vulnerable to hold-up behavior, since once the costs of creating the content

358 United States v. Jerrold Elecs Corp., 187 F. Supp. 545, 557 (E.D. Pa. 1960), aff'd, 365 U.S. 567 (1961) (per curiam); see also Owen \& Rosston, supra note 356, at 19 ("In the early stages of a technology with competitive alternatives, reputation may be a critical feature of marketing. Therefore integrated service leading to high quality, customer service and ultimately customer satisfaction may be very pro-competitive.").

359 Owen \& Rosston, supra note 356, at 13-14.

360 Henry B. McFarland, Economic Perspectives on Requiring Unbundled Access to Cable Broadband Networks 22 (unpublished manuscript, presented at the 2000 Annual Meeting of the ABA Section of Antitrust Law, July 11, 2000), available at http://www.abanet.org/ftp/pub/antitrust/ committees/communication/econ_perspec.doc. 
are sunk, the content owners' customers can try to beat them down to marginal cost.

Conversely, cable modem providers are similarly vulnerable to sunk cost opportunism. They are making a multi-billion dollar investment in their physical plant. Once the costs are sunk, cable modem providers bear the risk of being beaten down to levels at which the fixed-cost investment can no longer be recovered. ${ }^{361}$ The traditional method for redressing both of these concerns is either vertical integration or long-term exclusive dealing contracts. If unable to rely on such exclusive dealing arrangements, an inherently unstable situation results in which the reservation prices overlap significantly and in which both sides are left to settle on price through strategic behavior.

Free Riding. Integrated provision can be particularly important when a new technology is involved, since the need for presale services typically required by the introduction of a new technology increases the dangers of classic Telserian free riding. ${ }^{362}$ If multiple ISPs are available, they will all have the incentive to underinvest in promotional activities, an effect that can be particularly damaging in the early days of a new business when the burden of the sunk costs is spread over the smallest number of customers. ${ }^{363}$ Furthermore, the speeds attainable via cable modem systems are determined by both the quality of the transport network provided by the cable operator, as well as the amount of server space provided by the ISP. A cable modem subscriber that receives poor service may not be able to determine whether it is the ISP or the transmission provider that is the cause of the problem. ${ }^{364}$ This ambiguity creates some incentive for each party to shirk. Furthermore, as the courts recognized in one of the earliest decisions involving cable television, inability to manage this potential problem may drastically increase the risks involved in deploying the new technology, since customers that experience unsatisfactory performance with emerging technologies may simply choose to drop the product without attempting to identify the cause of the poor performance. ${ }^{365}$

The potential for congestion also raises the possibility of free riding. Since each user and each ISP do not internalize all of their costs, each has inadequate incentives to conserve bandwidth. ${ }^{366}$ In addition, the cable modem provider will eventually have to make additional capital investments to upgrade its system to accommodate increases in traffic. Theoretically, simply forcing each ISP to bear the full costs of their usage

361 Owen \& Rosston, supra note 356, at 22.

362 Telser, supra note 97.

363 Owen \& Rosston, supra note 356, at 13-14.

364 McFarland, supra note 360, at 23; Owen \& Rosston, supra note 356, at 14.

365 United States v. Jerrold Elecs. Corp., 187 F. Supp. 545, 556-57 (E.D. Pa. 1960), aff'd, 365 U.S. 567 (1961) (per curiam).

366 McFarland, supra note 360, at 23. 
could solve such problems. To the extent that open access is limited to marginal cost, however, the existence of such externalities also gives ISPs the incentive to free ride on the cable modem provider by avoiding making any contribution to the additional capital costs that the ISP itself is responsible for creating. Even if regulators attempt to allocate such fixed costs fully, the allocation of fixed costs has proven quite difficult and even arbitrary. In addition, rate making authorities have had little success setting the appropriate cost of capital to reflect the true ex ante risks once the market has arrived in the ex post world.

Adverse Selection. Broadband transport services are also subject to two types of adverse selection problems. The first stems from the inability to determine ex ante which portions of the cable modem network are likely to be the most profitable. In such cases, a unified provider can focus on average profitability, trusting that those areas which turn out to be relatively less profitable will tend to be balanced by other areas that turn out to be relatively more profitable. Open access, however, allows competing ISPs to wait until the relative profitability of each part of the network is revealed and then to simply offer ISP services only in the most attractive areas of the network. Not only does this allow the competing ISP to avoid bearing its fair share of the overall risk of the venture, it also prevents the cable modem provider from using the different parts of the system to offset these risks.

In addition, cable modem service is subject to a second adverse selection problem resulting from the fact that cable modem systems are subject to congestion. Cable modem providers cannot measure the intensity with which particular individuals use the system. In the absence of the ability to sort customers, unaffiliated ISPs can avoid the costs of their use of the bandwidth and have inadequate incentives to conserve bandwidth. Unless vertical integration is allowed and open access is forbidden, the cable modem provider has little choice but to engage in costly measures to meter usage, to build in contractual protections, or to sort users. ${ }^{367}$

It is thus possible to identify several plausible ways in which vertical integration can promote efficiency in the cable modem industry. It is not my purpose to prove that such efficiencies actually exist in any particular case. The mere possibility of such efficiencies serves to rebut arguments that vertical integration is so unlikely to be pro-competitive that the practice may be prohibited without any inquiry into the facts of specific cases.

367 Id. at 23-24. 


\section{Post-Chicago Models of Open Access}

The only major post-Chicago analysis of open access to appear to date was offered by economists Daniel Rubinfeld and $\mathrm{Hal}$ Singer in connection with the AOL-Time Warner merger. ${ }^{368}$ Rubinfeld and Singer base their analysis on two closely related articles, the first being the discursive analysis proffered by Michael Riordan and Steven Salop ${ }^{369}$ and the second being the formal model derived by Janusz Ordover, Garth Saloner, and Steven Salop ${ }^{370}$ from which the Riordan and Salop analysis draws its theoretical justification. ${ }^{371}$

The heart of Ordover, Saloner, and Salop's analysis is its reliance on a form of oligopolistic competition known as "Bertrand competition.",372 One of the unique qualities of Bertrand competition is that it supposes that two competitors are sufficient to drive the price down to competitive levels. Thus, unlike under other oligopolistic analyses in which reductions in the number of competitors gradually lead to increasingly anticompetitive results, under Bertrand competition, the existence of as few as two competitors is sufficient to drive prices down to the levels that would result under perfect competition. This phenomenon is known as the "Bertrand paradox." Thus, any reduction in the number of competitors does not force the market away from the perfectly competitive result until only two competitors remain. The elimination of one of these two remaining competitors, however, causes the market to shift abruptly and discontinuously from the perfectly competitive result to the monopolistic result. $^{373}$

The Ordover, Saloner, and Salop model takes advantage of this large discontinuous change to generate the only model that indicates that vertical integration unambiguously leads to higher prices for consumers. ${ }^{374}$ It posits a market composed of successive duopolies, in which two input suppliers sell to two downstream manufacturers. Despite the extreme concentration of both of these levels of production, the market is presumed to be completely efficient, since under Bertrand competition the existence of two input suppliers is sufficient to yield the perfectly competitive result. Vertical integration between one of the suppliers and one of the manufacturers causes the input market to change from a duopoly to a

368 Rubinfeld \& Singer, supra note 13.

369 Id. at 642-43, 647, 653-54, 656-57 (citing Riordan \& Salop, supra note 131)

370 Id. at 655 (citing Ordover et al., supra note 131).

371 See William E. Cohen, Competition and Foreclosure in the Context of Installed Base and Compatibility Effects, 64 ANTITRUST L.J. 535, 562 n.162 (1996); Reiffen \&Vita, supra note 72, at 922 n.16, 925 .

372 On Bertrand competition, see generally CARLTON \& PERLOFF, supra note 135, at 166-72; CHURCH \& WARE, supra note 135, at 256-70; and TIROLE, supra note 24, at 205-06.

373 Ordover et al., supra note 131, at 127.

374 Snyder \& Kauper, supra note 135, at 594. 
monopoly. The resulting price increase by the non-vertically integrated firm unambiguously causes welfare to fall.

The post-Chicago models upon which Rubinfeld and Singer base their analysis have been subjected to several conceptual criticisms. The most questionable aspect of these models is the extent to which their result depends on the Bertrand paradox. Bertrand models depend upon a number of strong assumptions that may not hold with respect to the markets involved in the open access debate. For example, classic Bertrand models assume that the goods produced by the duopolistic competitors are perfect substitutes for one another. It is generally acknowledged that the Bertrand paradox collapses if the products are non-homogeneous, since any degree of product differentiation will give the firms sufficient market power to raise prices above competitive levels. ${ }^{375}$ Bertrand competition assumes that the duopolistic competitors will take their rival's prices as fixed and will not anticipate any actions. As Timothy Muris, the newly appointed Chairman of the FTC, has noted, such an assumption is empirically untested and is likely to be theoretically unsound. ${ }^{376}$

In addition, the anti-competitive effect described in the OrdoverSaloner-Salop model depends on the assumption that only two firms exist at each level of production. The existence of a third competitor (or a potential entrant) will cause the anti-competitive effects to disappear. ${ }^{377}$ In addition, in order for the Bertrand paradox to spring, the firm that vertically integrates must use all of the input it produces internally. If the company continues to sell the input to other customers, vertical integration does not have the effect of reducing the number of competitors. As David Reiffen has pointed out, Ordover, Saloner, and Salop fail to explain why or how a company could precommit to forego external sales. ${ }^{378}$

Finally, these models fail to take into account the possibility of efficiencies resulting from the merger. By assuming that two firms are sufficient to force price down to competitive levels, the Ordover, Saloner, and Salop model, by its nature, precludes any possible welfare benefits resulting from the elimination of double marginalization even though the successive duopoly structure strongly suggests that such efficiencies would exist. ${ }^{379}$ In addition, the model fails to take into account the possibility that vertical integration could rationalize input substitution in ways that

375 See, e.g., CARLTON \& PERLOFF, supra note 135, at 217; CHURCH \& WARE, supra note 135 , at 258-64; TIROLE, supra note 24 , at $212,277-78$.

376 Muris, supra note 236, at 311.

377 See Klass \& Salinger, supra note 128, at 682; Snyder \& Kauper, supra note 135, at 594. (1992)

378 David Reiffen, Equilibrium Vertical Foreclosure; Comment, 82 AM. ECON. REV. 694

379 See Hovenkamp, Post-Chicago, supra note 128, at 325-26; Klass \& Salinger, supra note 128, at 681-82; Reiffen \& Vita, supra note 72, at 929; Snyder \& Kauper, supra note 135, at 594-95. For the discussion on double marginalization, see supra notes 84-88 and accompanying text. 
promote efficiency, ${ }^{380}$ as well as the possibility of significant transaction cost savings. These problems have led even those economists firmly committed to regulatory intervention to question the utility of Bertrand models. ${ }^{381}$ Although some of the refinements offered by Riordan and Salop mitigate some of these problems, these concerns raise serious questions as to whether vertical integration yields such unambiguously anti-competitive outcomes so as to justify prohibiting it as a regulatory matter.

For the purposes of this Article, we need not come to any definitive resolution of these issues. As Rubinfeld and Singer acknowledge, the models upon which they base their argument depend on the same structural assumptions employed in my analysis. Specifically, Rubinfeld and Singer acknowledge that (1) the market for broadband transport services must be concentrated and burdened by high switching $\operatorname{costs}^{382}$ and (2) the market for ISPs must be concentrated and protected by barriers to entry. ${ }^{383}$ Their support for compelling open access as a condition of the AOL-Time Warner merger depended upon their assumption that the HHI in the residential broadband transport market was 5673, that DSL was unlikely to emerge as a competitor to cable modem service, and that switching costs among the services was likely to be high. ${ }^{384}$ Thus any disagreement with their position can be resolved simply by showing that these preconditions have not been met. For the reasons discussed above, ${ }^{385}$ I believe that such preconditions have not been met with respect to open access.

\section{The Empirical Evidence on Open Access}

Despite the relative youth of the broadband transport industry, one relevant empirical study on open access has already appeared in the literature. Thomas Hazlett and George Bittlingmayer designed an event study to determine the impact that positive and negative news concerning open access had on three different metrics: (1) a general index of Internet stocks, (2) the stock price of Excite@Home (to serve primarily as a control), and (3) the stock price of America Online. All three were

380 See Reiffen \& Vita, supra note 72, at 929-30; Snyder \& Kauper, supra note 135, at 595. For the discussion on the welfare impact of vertical integration when inputs can be used in variable proportions, see supra notes 72-79 and accompanying text.

381 F.M. Scherer, Comment, in BROOKINGS PAPERS: MiCroeConomics 323 (1991) ("We economists love ... Bertrand models because we can have a good bash at them with the powerful tools of calculus. ... We have known at least since Edward Chamberlain published his famous book nearly sixty years ago that [Bertrand models are based on] unrealistic assumptions."). $539-45)$.

382 Rubinfeld \& Singer, supra note 13, at 648-50 (citing Riordan \& Salop, supra note 131, at

383 Id. at 646-47 \& n.54 (citing Riordan \& Salop, supra note 131, at 533).

384 Id. at $649-52$.

385 See supra Subsections III.B.1-2. 
adjusted for changes in the S\&P 500 index. If vertical integration and exclusivity did not yield net efficiency benefits and open access on balance enhanced efficiency, one would expect that setbacks to open access would have negative impacts on the Internet index and the stock price of AOL, while victories for open access would have a positive impact on both metrics. In fact, precisely the opposite was true, as setbacks to the open access movement were correlated with an increase in both the Internet index and the stock price of AOL, with the former effect being statistically significant. Hazlett and Bittlingmayer thus concluded that the data tended to be more consistent with the idea that vertical integration yielded net efficiency benefits than with the hypothesis that open access would be more beneficial. ${ }^{386}$ Although changes in stock prices and indices are subject to numerous other influences and, as a result, are admittedly imperfect measures of efficiency, in the absence of better evidence, this study does provide some preliminary support for the position that vertical integration in the cable modem industry may promote efficiency.

\section{The Problematic Nature of Compelled Access as a Remedy}

For the same reasons described more completely in the discussion of the use of access remedies in cable television, ${ }^{387}$ it is likely that open access will prove problematic as a remedy. First, as noted earlier, access remedies by their nature depend on theories of leveraging and foreclosure that have largely been discredited ${ }^{388}$ and, in any event, depend on the existence of structural preconditions, including market power in the primary market and the existence of barriers to entry in the secondary market, that are not satisfied in the current case.

Second, the terms under which access is compelled are likely to be very difficult to administer. If the FCC were to compel access without imposing any restrictions on price, a cable modem provider would simply charge the monopoly price. While such access would clearly benefit other ISPs by rescuing them from having to make the capital investments that would have otherwise been required for them to secure carriage through other means, it would provide no tangible benefit to consumers, as price and output would remain at monopoly levels. Attempts at forcing prices below monopoly levels, however, would force regulators to referee a

386 Thomas W. Hazlett \& George Bittlingmayer, The Political Economy of Cable "Open Access," 2001 STAN. TECH. L. REV,, (forthcoming Fall 2001), available at http:/www.manhattaninstitute.org/hazlett/working_01_06.pdf.

387 See supra Subsection II.C.

388 See e.g., Speta, Vertical Dimension, supra note 21, at 996. 
never-ending series of disputes over the terms and conditions of access, a role for which the FCC has historically proven ill-suited. ${ }^{389}$

Most importantly, the economic literature suggests that open access would harm dynamic efficiency as well, by slowing the deployment of high-speed broadband services. The fact that any positive developments would need to be shared with competitors would represent a deviation from the well-defined property rights needed to provide cable modem operators with the incentive to engage in efficient levels of investment in their own technology. ${ }^{390}$ In addition, compelled access would also rescue unaffiliated ISPs from having to support the development of alternative broadband providers. These unaffiliated ISPs represent the natural strategic partners for DSL, satellite, and other broadband transport providers seeking to build services to compete directly with cable modem services. Providing unaffiliated ISPs with access to cable modem systems would remove any incentive to support such initiatives.

This insight underscores the core problem in the broadband industry, which is the paucity of providers capable of delivering broadband transport services into the home. An open access regime would do nothing to alleviate this central problem, since choice among ISPs will not provide consumers with any additional options for broadband transport services. Giving consumers their choice of ISP will thus not allow them to pay less than the monopoly price. Likewise, allowing vertical integration between cable modem services and ISPs will not make this problem any worse. On the contrary, open access will make the problem worse by preventing cable modem providers from realizing the available efficiencies and by depriving DSL and other alternative broadband transport providers of their natural strategic partners

\section{The New Economy Arguments: The Effect of Standardization on Innovation}

Open access advocates have gone far beyond the conventional economics of vertical integration and instead have turned to arguments inspired by various features of the New Economy. Led by Professors

389 See Owen \& Rosston, supra note 356 , at 20-22; McFarland, supra note 360 , at 27; see also supra text accompanying note 289 . As noted earlier, such problems can be mitigated if the bottleneck facility sells to multiple customers. See supra note 287 . Following the collapse of Excite@Home, it is increasingly likely that each broadband transport provider will be paired with a dedicated ISP.

390 Owen \& Rosston, supra note 356, at 15, 17; Daniel Shih, Comment, Open Access or Forced Access: Should the FCC Impose Open Access on Cable-Based Internet Service Providers?, 52 ADMIN. L. REV. 793, 806 (2000). This argument is not, as Lemley and Lessig suggest, that monopoly profits are needed to "prim[e] the pump." Lemley \& Lessig, supra note 16, at 957-62. Well-defined property rights play an essential role in encouraging investment even when monopoly power is not involved. 
Lemley and Lessig's recent article, this distinguished group of scholars has raised a wide range of arguments based on innovation theories and network economics. First advanced as considerations that should guide merger policy, ${ }^{391}$ more recent work has suggested that these arguments should serve as a guide to regulatory policy as well. ${ }^{392}$ The importance of these arguments justifies discussing them in detail.

Professors Lemley and Lessig's central contention is that the failure to impose open access would threaten innovation on the Internet. In their eyes, innovation on the Internet depends on the maintenance of the "endto-end" design principle that has ensured that the Internet has remained fully interoperable since its inception. At the core of this principle is the belief that the functions of the Internet involved in transporting data between computers should be as simple and general as possible and should not be tailored towards any particular application. The computers connected to the ends of the network (rather than the network itself) should provide the functionality of particular applications. Put more simply, the connections between the computers should be as "dumb" as possible and should focus on carrying bits and bytes between computers as quickly as possible without performing any additional functions. The "intelligence" in the network should instead reside at the edges. ${ }^{393}$

Professors Lemley and Lessig believe that innovation on the Internet depends upon the continued standardization provided by this end-to-end architecture. As a result, they condemn the agglomeration of broadband transport providers and ISPs that threatens this standardization by permitting proprietary networks to introduce a greater degree of intelligence into the body of the network itself. In addition, Lemley and Lessig contend that the end-to-end architecture of the Internet encourages innovation by shifting the locus of creativity away from centralized control by dominant firms and towards a more diverse array of smaller innovators. ${ }^{394}$ Lemley and Lessig also assert that the empirical evidence indicates that creativity is better spurred by more competitive market structures. ${ }^{395}$

Finally, Lemley and Lessig argue that open access is necessary to ensure the new type of competition that is emerging in the New Economy. Drawing on the work of Timothy Bresnahan, ${ }^{396}$ they contend that

391 Mark A. Lemley \& Lawrence Lessig, Open Access to Cable Modems, 22 WHITTIER L. REV. 3 (2000) (reprinting ex parte declaration filed in connection with the AT\&T-MediaOne merger).

392 Lemley \& Lessig, supra note 16, at 971.

393 Id. at $931-32$.

394 Id. at 943.

395 Id. at 961.

396 Timothy F. Bresnahan, New Modes of Competition: Implications for the Future Structure of the Computer Industry, in COMPETIIION, INNOVATION AND THE MICROSOFT MONOPOLY: 
competition in the broadband industry will differ from competition in more conventional industries. Bresnahan argues that, unlike in conventional industries in which the manufacturing, wholesale, and retail levels are each occupied by several participants engaging in vigorous competition, the presence of large economies of scale will cause each level of the broadband industry to become dominated by a single player. Although strategic entry barriers and cost asymmetries appear to play some role, the primary cause of market concentration at each level is the presence of strong network externalities. ${ }^{397}$ Jerry Hausman, Gregory Sidak, and Hal Singer advance a similar argument. ${ }^{398}$ They argue that the existence of network economic effects can allow the early leader in the race to provide broadband Internet access to "lock in" subscribers and content providers. The existence of these network externalities can deter innovation by making it prohibitively expensive for subscribers and content providers to switch to alternative platforms, even when it might be in their best interests to do so. ${ }^{399}$

These scholars should be applauded for advancing such an important and innovative perspective. Clearly any policy evaluation in this area must take into account the impact of standardization and network externalities on innovation. That said, my review of the literature on the relationship between innovation, standardization, concentration, and network economics reveals that the relationship between these factors is more ambiguous than Professors Lemley, Lessig, and those advancing similar arguments would have us believe. If anything, it appears that permitting competing proprietary standards to emerge might help to mitigate, rather than exacerbate, some of the problems that may also emerge. Finally, the literature raises serious questions regarding the propriety of open access as a solution. In fact, the argument offered by Timothy Bresnahan, upon which Lemley and Lessig rely, suggests that even if firms achieve dominance over particular levels of production, open access may ultimately prove counterproductive.

\section{The Tradeoff Between Standardization and Product Diversity}

First, it bears noting that standardization and openness can deter, as well as encourage, innovation. Scholars who have studied the problems of standardization in the face of network economic effects have long

ANTITRUST IN THE Digital MARKETPlace 155 (Jeffrey A. Eisenach \& Thomas M. Lenard eds., 1999).

397 Id. at $159-65$.

398 Jerry A. Hausman et al., supra note 13, at 129.

399 Id. at 161-62, 163-64; see also Jerry A. Hausman et al., Cable Modems and DSL: Broadband Internet Access for Residential Customers, 91 AM. ECON. REV. 302, 306 (2001). 
recognized that standardization necessarily limits product variety by "prevent[ing] the development of promising but unique and incompatible new systems., ${ }^{, 400}$ The resulting limits on possible innovation leave consumers with a narrower range of products from which to choose. ${ }^{401}$ Indeed, the introduction of proprietary standards may simply represent the natural outgrowth of heterogeneous consumer preferences. ${ }^{402}$ Professors Lemley and Lessig implicitly concede as much when they recognize that it is the need for greater security and the growth of e-commerce that is leading network providers to move away from standard protocols and to introduce greater levels of intelligence into the network itself. The clear consumer benefits provided by the development of the commercial potential of the Internet lead Lemley and Lessig to recognize that a move towards proprietary standards may be "inevitable." of security flaws in certain commonly used Internet protocols only serves to underscore the potential security dangers associated with the use of uniform standards. ${ }^{404}$

Similarly, even scholars concerned about the dangers of closed systems have acknowledged that exclusivity can similarly serve procompetitive functions, in that it "can serve to differentiate products and networks, to encourage investment in these networks, and to overcome free-riding." ${ }^{405}$ As a result, these scholars have uniformly rejected applying a rule of per se illegality to such arrangements. ${ }^{406}$

\section{The Relationship Between Market Concentration and Innovation}

Professors Lemley and Lessig further oppose permitting cable modem providers to exert too much control over the architecture of the Internet on

400 Michael L. Katz \& Carl Shapiro, Systems Competition and Network Effects, 8 J. ECoN. PERSP. 93, 110 (1994).

401 See id. (noting that "the primary cost of standardization is loss of variety: consumers have fewer differentiated products to pick from"); Joseph Farrell \& Garth Saloner, Standardization. Compatibility, and Innovation, 16 RAND J. ECON. 70, 71 (1985) (counting "reduction in variety" as one of the "important social costs" of standardization).

402 See Katz \& Shapiro, supra note 400, at 106 (noting that "market equilibrium with multiple incompatible products reflects the social value of variety"); S.J. Liebowitz \& Stephen E. Margolis, Should Technology Choice Be a Concern of Antitrust Policy?, 9 HARV. J.L. \& TECH. 283, 292 (1996) ("Where there are differences in preference regarding alternative standards, coexistence of standards is a likely outcome.").

403 Lemley \& Lessig, supra note 16, at 939.

404 See Hiawatha Bray, Software Flaw May Pose Risk for Net Users, Boston Globe, Mar. 13, 2001, at D2 (discussing security flaw in TCP/IP); James Glanz, Cryptologists Discover Flaw in EMail Security Program, N.Y. TIMES, Mar. 21, 2001, at A14 (discussing security flaw in commonly used encryption program).

405 Carl Shapiro, Exclusivity in Network Industries, 7 GEo. MASON L. Rev. 673, 678 (1999).

406 Id. ("I am certainly not proposing a per se rule against exclusivity in a network context."); TIROLE, supra note 24 , at 186 ("Theoretically, the only defensible position on vertical restraints seems to be the rule of reason. . . Legality or illegality per se . . seems unwarranted."). 
the grounds that "the empirical evidence suggests quite strongly that it is competition, not monopoly, that best spurs creativity." proposition, they cite two pieces of data: (1) a recent study by Professor Howard Shelanski ${ }^{408}$ of the speed with which innovations in the telecommunications industry were deployed and (2) the empirical evidence about the relationship between market concentration and innovation on the Internet. ${ }^{409} \mathrm{My}$ own review of both of these sources reveals that the relationship between market concentration and innovation is more ambiguous than Lemley and Lessig suggest.

The Shelanski Study. This ambitious work identified ten recent innovations in telecommunications and measured both the market structure under which each was deployed, as well as the length of time between the initial deployment of the technology and the time each technology was deployed in thirty percent of the relevant network points. ${ }^{410}$ Specifically, Professor Shelanski identified whether a particular innovation was deployed under one of three market structures: (1) monopoly conditions, (2) "concentrated oligopoly conditions," defined as competition restricted to two or three firms, and (3) "competitive oligopoly conditions," defined as competition among more than three firms. ${ }^{411}$ Professor Shelanski then calculated the average deployment time for technologies deployed under monopoly conditions ( 9 years), concentrated oligopoly conditions ( 8 years), and competitive oligopoly conditions (4.3 years). This led Professor Shelanski to conclude that faster deployment times correlate with more competitive market structures. ${ }^{412}$

The care with which Professor Shelanski frames his empirical study makes it particularly important to pay close attention to the caveats that he attaches to his work. First of all, Shelanski himself concedes that his results are far from conclusive. Given the relatively small number of observations and the high degree of variance within each category, it comes as no surprise that Shelanski made no attempt to evaluate whether the differences were statistically significant. Even a casual review of the numbers reveals that even a small change in almost any of them would

407 Lemley \& Lessig, supra note 16, at 961

408 Howard A. Shelanski, Competition and Deployment of New Technology in U.S. Telecommunications, 2000 U. CHI. LEGAL F. 85

409 Lemley \& Lessig, supra note 16, at 961-62.

410 Shelanski, supra note 408 , at 99.

411 According to Shelanski, four innovations were deployed under monopoly conditions: touch-tone dialing, digital stored-program-control switching, ISDN transmission, and electronic storeprogram-control switching. Three other innovations were deployed under concentrated oligopoly conditions: SS-7 signaling, fiber-optic transport, and automatic switching. Three other innovations were deployed under competitive oligopoly conditions: DSL service, cable modem service, and digital wireless telephony. See id. at 98-114 (describing these various innovations in detail).

412 Id. at 115. 
Table IX. Deployment of Ten Telecommunications Innovations

\begin{tabular}{llll}
\hline $\begin{array}{l}\text { Market } \\
\text { Structure }\end{array}$ & Technology & $\begin{array}{l}\text { Time to } 30 \% \\
\text { Deployment }\end{array}$ & $\begin{array}{l}\text { Average Time } \\
\text { to Deployment }\end{array}$ \\
\hline & Touch-tone dialing & 4 years & \\
Digital stored-program- & 7 years & \\
control switching & 9 years \\
& ISDN transmission & 9 years & \\
& $\begin{array}{l}\text { Electronic stored-program- } \\
\text { control switching }\end{array}$ & 14 years & \\
\hline $\begin{array}{l}\text { Concentrated } \\
\text { Oligopoly }\end{array}$ & FS-7 signaling & 4 years & \\
& & 6 years & 8 years \\
& Automatic switching & 12 years & \\
\hline $\begin{array}{l}\text { Competitive } \\
\text { Oligopoly }\end{array}$ & Cable modem service & 3 years & 4.3 years \\
& Digital wireless & 7 years & \\
\hline
\end{tabular}

Source: Shelanski, supra note 408 , at 116.

likely have a drastic impact on the results. It also bears mentioning that Shelanski's study focused on the time it took to deploy technologies that had already been developed rather than innovative activity proper. ${ }^{413}$ Indeed, as Shelanski specifically notes, many of the innovations that he studied had lain fallow for several years after their initial development. ${ }^{414}$ As such, his study is more properly regarded as focusing on investment rather than innovation, since it measures the time it took to deploy technologies that had already been developed rather than the time needed to create the technological innovations in the first place. Shelanski also

413 See id. (noting that the key measurement in the study was the length of time between the date of initial deployment and the date when thirty percent deployment was reached).

414 See id. at 99 (touch-tone dialing was developed in the late 1950 s, but not deployed until 1963), 105 (SS-7 signalling was developed in the 1970s, but not deployed until 1987), 111 (DSL was developed in 1989, but not deployed until 1996). 
correctly notes that finding a correlation says nothing about causation. ${ }^{415}$ Indeed, as Joseph Schumpeter famously suggested, it is quite possible that innovative activity causes market concentration and not the other way around. ${ }^{416}$

In addition, Shelanski recognizes that the speed with which a new technology is deployed depends on a wide range of considerations aside from market concentration. Differences in costs and benefits can have a large impact on deployment rates. ${ }^{417}$ Similarly, the leading commentary on product diffusion has recognized that a wide range of factors can affect the speed of product diffusion, including (1) the relative advantage conferred by the new product, (2) the compatibility of the new product with existing products, (3) the complexity of the product, (4) the new product's trialability, and (5) the observability of the innovation to others. ${ }^{418}$ Other relevant factors include initial costs, ongoing costs, risk and uncertainty, scientific credibility, and social approval. ${ }^{419}$ Most importantly, since all of the innovations studied occurred in a heavily regulated industry, Shelanski was unable to determine whether some other factor correlated with market concentration might, in fact, be the true causal driver of the effect he observed. These would include a wide variety of factors, including "pricing rules, service requirements, subsidy flows and other regulatory and institutional factors."

Finally, and most importantly, the conclusion that Shelanski draws suggests that he would disagree with any attempts to draw simple policy inferences from his work. Shelanski simply argues that the data provided "sufficient support for an initial presumption that competition and implementation of new technology are mutually reinforcing, rather than conflicting, objectives." ${ }^{421} \mathrm{He}$ concedes that the record is too mixed and the data points too few to support a conclusive presumption. His work thus does not support the kind of categorical determination against such

415 Id. at 117.

416 JOSEPH A. SCHUMPETER, CAPITALISM, SOCIALISM AND DEMOCRACY 81-86 (1942).

417 Shelanski, supra note 408, at 114-15.

418 EVERETT M. ROGERS, DIFfusion OF INNOVATIONS 240-51 (4th ed. 1995). This framework represents the basic analytical approach reflected in many of the leading marketing textbooks. See, e.g., Philip Kotler, MARKet MANAGEMent 357 (Millennium ed. 1999); Thomas S. ROBERTSON, JOAN ZIELINSKI, \& SCOTT WARD, CONSUMER BEHAVIOR 373-76 (1984).

419 KoTler, supra note 418, at 442; Minhi Hahn, Sehoon Park, \& Andris A. Zoltners, Analysis of New Production Diffusion Using a Four-Segment Trial-Repeat Model, 13 MARKETING SCI. 224 (1994); Vijay Mahajan, Eitan Muller, \& Frank M. Bass, Diffusion of New Products: Empirical Generalizations and Managerial Uses, 14 MARKETING SCl. G79 (1995); Fareena Sultan, John U. Farley, \& Donald R. Lehmann, Reflection on "A Meta-Analysis of Applications of Diffusion Models," 33 J. MARKETING RES. 247 (1996).

420 Shelanski, supra note 408 , at 86 .

421 Id. at 117. 
consolidation that would be embodied in a regulation imposing open access. Indeed, Shelanski's other work strongly suggests the contrary. ${ }^{42}$

Empirical Studies of the Relationship Between Concentration and Innovation. Professors Lemley and Lessig suggest that "the empirical evidence suggests quite strongly that it is competition, not monopoly, that spurs creativity. ${ }^{, 423}$ My own review of the extensive empirical literature on this question indicates that, as a general matter, the relationship between innovation and market structure is more ambiguous than Lemley and Lessig suggest. ${ }^{424}$ While some studies found that increases in research and development tended to be associated with high market concentration, ${ }^{425}$ other studies came to precisely the opposite conclusion. ${ }^{426}$ Still others studies argued that the relationship between market concentration and innovation was non-linear. Under these analyses, innovative activity is at its lowest when the market is either highly competitive or monopolistic and at its highest at moderate levels of concentration. If the level of innovation were drawn as a function of market concentration, the resulting pattern would thus appear as an "inverted-U." ${ }^{, 427}$ Still other studies suggest

422 See Shelanski, supra note 25 , at $739-44$ (arguing that competition could slow the deployment of broadband transport services).

423 Lemley \& Lessig, supra note 16 , at 48.

424 For useful surveys of the empirical literature, see MORTON I. KAMIEN \& NANCY L. SCHWARTZ, MARKET STRUCTURE AND INNOVATION 86-91 (1980); SCHERER \& ROSS, supra note 72, at 644-51; PAUl. STONeman, THE EConomic ANalysis of TeChNOlogiCal Change 46-49 (1983); Wesley M. Cohen \& Richard C. Levin, Empirical Studies of Innovation and Market Structure, in 2 HANDBOOK OF INDUSTRIAL ORGANIZATION, at 1059, 1074-78 (Richard Schmalensee \& Robert Willig eds., 1989).

425 See, e.g., EDWIN MANSFIELd, INDUSTRIAL RESEARCH AND TECHNOLOGICAL INNOVATION: AN ECONOMETRIC ANALYSIS (1968); F.M. SCHERER, INNOVATION AND GROWTH: SCHUMPETERIAN PERSPECTIVES 59-64 (1984); Louis Amato \& J. Michael Ryan, Market Structure and Dynamic Performance in U.S. Manufacturing, 47 S. ECON. J. 1105 (1981); A.J. Buxton, The Process of Technical Change in UK Manufacturing, 7 APPLIED ECON. 53 (1975); Douglas F. Greer \& Stephen A. Rhoades, Concentration and Productivity Changes in the Long and Short Run, 43 S. ECON. J. 1031 (1976); D. Hamberg, Size of Firm, Oligopoly, and Research: The Evidence, 30 CANADIAN J. ECON. \& POL. SCI. 62 (1964); Ira Horowitz, Firm Size and Research Activity, 28 S. ECON. J. 298 (1962); Albert N. Link, An Analysis of the Composition of R\&D Spending, 49 S. ECON. J. 343 (1982); Edwin Mansfield, Industrial Research and Development Expenditures: Determinants, Prospects, and Relation to Size of Firm and Inventive Output, 72 J. POL. ECON. 319 (1964); Edwin Mansfield, Composition of $R$ and $D$ Expenditures: Relationship to Size of Firm Concentration, and Innovative Output, 63 REV. ECON. \& STAT. 610 (1981); J.B. Rosenberg, Research and Market Share: A Reappraisal of the Schumpeter Hypothesis, 25 J. INDUS. ECON. 101 (1976); see also DANIEL HAMBERG, R\&D: ESSAYS ON THE ECONOMICS OF RESEARCH AND DEVELOPMENT 64-65 (1966) (finding a positive correlation between industry concentration and research and development spending but calling it weak).

426 See, e.g., BARRY BOZEMAN \& ALBERT N. LINK, INVESTMENTS NN TECHNOLOGY 53 (1983); Zoltan J. Acs \& David B. Audretsch, Innovation in Large and Small Firms: An Empirical Analysis, 78 AM. ECON. REV. 678, 686-87 (1988); Arun K. Mukhopadhyay, Technological Progress and Change in Market Concentration in the U.S., 1963-77, 52 S. ECON. J. 141 (1985); Oliver E. Williamson, Innovation and Market Structure, 73 J. POL. ECON. 67 (1965).

427 See, e.g., F.M. Scherer, Market Structure and the Employment of Scientists and Engineers, 57 AM. ECON. REV. 524 (1967); John D. Culbertson, Should Antitrust Use the Schumpeterian Model?: The Case of the Food Industries, in ISSUES AFTER A CENTURY OF FEDERAL COMPETITION POLICY 103, 106-07 (Robert L. Wills et al., eds., 1987); Richard C. Levin et al., $R \& D$ 
that understanding the relationship requires the study of variables. ${ }^{428}$ In particular, many studies have focused on the level of "technological opportunity" available to a particular industry, ${ }^{429}$ with some studies finding concentration to be particularly conducive to innovation when technological opportunity is high $^{430}$ and other studies finding the contrary. ${ }^{431}$ Given this confusing welter of information, it comes as no surprise that surveys of this literature have tended to describe it as

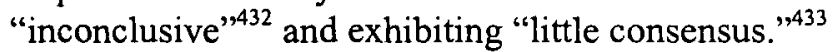

Thus, as Professors Lemley and Lessig acknowledge, ${ }^{434}$ there appears to be little empirical basis for believing that, as a general matter, higher levels of innovation are associated with lower levels of market concentration. In the end, their argument turns on their own observations on the relationship between open architecture and innovation with respect to the Internet and their belief that past performance has been sufficiently

Appropriability, Opportunity, and Market Structure: New Evidence on Some Schumpeterian Hypotheses, 75 AM. ECON. REV. 20 (1985); John T. Scott, Firm Versus Industry Variability in R\&D Intensity, in R\&D, PATENTS AND PRODUCTIVITY 233 (Zvi Griliches ed., 1984); B. Wahlroos \& M. Backström, R\&D Intensity with Endogenous Concentration, Evidence for Finland, 7 EMPIRICAL ECON. 13 (1982); Thomas Monroe Kelly, The Influences of Firm Size and Market Structure on the Research Efforts of Large Multiple-Product Firms 85-86 (1970) (unpublished Ph.D. dissertation, Oklahoma State University) (on file with author).

428 Reinhard Angelmar, Market Structure and Research Intensity in High-TechnologicalOpportunity Industries, 34 J. INDUS. ECON. 69 (1985); William S. Comanor, Market Structure, Product Differentiation, and Industrial Research, 81 Q.J. ECON. 639 (1967); J. Lunn \& S. Martin, Market Structure, Firm Structure, and Research and Development, 27 Q. REV. ECON. \& BUS. 31 (1986); Dennis C. Mueller \& John E. Tilton, Research and Development Costs as a Barrier to Entry, 2 CANADIAN J. ECON. 570 (1969); Ronald E. Shrieves, Market Structure and Innovation: A New Perspective, 26 J. INDUS. ECON. 329 (1978); Robert W. Wilson, The Effect of Technological Environment and Product Rivalry on R\&D Effort and Licensing of Inventions, 59 REV. ECON. \& STAT. 171 (1977).

429 See KAMIEN \& SCHWARTZ, supra note 424, at 91 ("There is agreement that the relation [between research efforts and concentration] may vary with the 'technological opportunity class' of the industry."). For useful surveys of this literature, see Cohen \& Levin, supra note 424, at 1083-90; KAMIEN \& SCHWARTZ, supra note 424, at 58-64, 88-90; SCHERER \& ROSS, supra note 72, at 646-49; STONEMAN, supra note 424 , at $47-49$.

430 Kelly, supra note 427; Almarin Phillips, Patents, Potential Competition, and Technical Progress, 56 AM. ECON. REV. 301 (1966); F.M. Scherer, Firm Size, Market Structure, Opportunity and the Output of Patented Inventions, 55 AM. ECON. REV. 1097 (1965); Scott, supra note 427.

431 F.M. SCHERER, INNOVATION AND GROWTH: SCHUMPETERIAN PERSPECTIVES 24-46 (1984); W.J. Adams, Firm Size and Research Activity: France and the United States, 84 Q.J. ECON. 386 (1970); P. A. Geroski, Innovation. Technological Opportunity, and Market Structure, 42 OXFORD ECON. PAPERS 586 (1990); Steven Globerman, Market Structure and R\&D in Canadian Manufacturing Industries, 13 Q. REV. ECON. \& BUS. 59 (1973); Henry G. Grabowski, The Determinants of Industrial Research and Development: A Study of the Chemical, Drug, and Petroleum Industries, 76 J. POL. ECON. 292 (1968); John Lunn, An Empirical Analysis of Process and Product Patenting: A Simultaneous Equation Framework, 34 J. INDUS. ECON. 319 (1986); Lunn \& Martin, supra note 428; Rosenberg, supra note 425; Shrieves, supra note 428.

432 Cohen \& Levin, supra note 424, at 1061.

433 KAMIEN \& SCHWARTZ, supra note 424 , at 91.

434 Lemley \& Lessig, supra note 16, at 961 (recognizing that whether competition or monopoly better fosters innovation "is not a question that can be answered a priori, but only by reference to actual cases"). 
meritorious to justify erecting a presumption in favor of the status quo. ${ }^{435}$ Lemley and Lessig may well be correct. Unfortunately, it is impossible to verify such a claim, since one cannot determine whether the world would have been more or less innovative had the Internet taken a different structure. Given that the imposition of open access is tantamount to a declaration that vertical integration in this industry is per se illegal, the unlikelihood of economic harm and the real possibility of efficiencies identified by conventional vertical integration theory would seem to make it more appropriate to place the burden of proof on those who would impose open access regulation. The ambiguities surrounding the relationship between market structure and innovation should lead us to require more than casual empiricism before enacting what would amount to a declaration of per se illegality.

\section{Network Externalities and Vertical Competition}

Finally, in relying on the work of Timothy Bresnahan, ${ }^{436}$ Professors Lemley and Lessig implicitly base their argument in favor of preserving the Internet's end-to-end architecture on a theory of network externalities. As I noted earlier, other open access advocates have advanced similar arguments. ${ }^{437}$ My principal concern about such arguments is that, all too often, the existence of network externalities is automatically associated with the phenomena of "tipping" and "lock in." An examination of the economic literature reveals that reducing network externalities to the harms to innovation associated with these phenomena is far too simplistic and that a correct application of network economic principles yields a far more complex (and ambiguous) perspective.

\section{a. The Ambiguous Impact of Network Economic Effects on Innovation}

As noted above, network economics are almost invariably cited for the fact that the presence of network externalities can harm innovation by causing an inferior technology to become locked in. A review of the leading articles on the subject reveals that such a perspective is far too simplistic. As Joseph Farrell and Garth Saloner have pointed out, a consumer's decision to adopt a new technology actually gives rise to two distinct and countervailing externalities. When the value of a network

435 Id. at $933,961-62$.

436 Id. at 942. In his other work, Lemley recognizes that the policy implications of network economics are quite ambiguous. See Mark A. Lemley \& David McGowan, Legal Implications of Network Economic Effects, 86 CAL. L. REV. 479, 498-99, 591-601 (1998).

437 E.g., Hausman et al., supra note 13, at 161-64. 
depends on the number of people using the network, any decision to adopt a new technology enhances the value of the new network to those who have already adopted it as well as to those who will adopt it in the future. ${ }^{438}$ Because the person adopting the new technology is thus unable to capture all of the benefits created by his or her adoption decision, individuals may refrain from adopting a new technology even when it would be socially beneficial for them to do so. ${ }^{439}$ The existence of such positive externalities (i.e., benefits that the person adopting the new technology is unable to capture) may make the market reluctant to adopt a new technology, even when doing so is in society's best interest. This can cause markets to become "locked in" to obsolete technologies, a phenomenon that Farrell and Saloner refer to as "excess inertia.,"440

At the same time, however, the adoption of a new technology also gives rise to a countervailing negative externality that may produce precisely the opposite effect. This is because any decision to adopt a new technology also lowers the value of the old technology by reducing the number of people using it. Individuals considering adopting a new technology thus do not fully internalize the costs created by their decision. This may make an individual willing to adopt a new technology even when the net costs to society exceed the net benefits, a situation variously called "excess momentum" 441 or "insufficient friction." 442 It is thus theoretically possible that the presence of network economic effects may accelerate, rather than retard, the pace with which new technologies are adopted. The impact of network externalities on innovation thus depends upon which of these two externalities dominates. This is an empirical question that cannot be simply asserted.

In addition, the economic literature also identifies a number of other features relevant to the broadband transport industry that can mitigate, or even eliminate, whatever problems are caused by network externalities. For example, excess inertia can be overcome if the value of the new product introduction exceeds the value of maintaining standardization. ${ }^{443}$ As Steven Kaplan and Mark Ramseyer succinctly put it, "an entrenched

438 Joseph Farrell \& Garth Saloner, Installed Base and Compatibility: Innovation, Product Preannouncements, and Predation, 76 AM. ECON. REV. 940, 941 (1986).

439 Farrell and Saloner also point out that this burden will rest particularly heavily on the earliest adopters, and that "[o]nce the first potential adopters decide not to adopt the new technology, ... the excess inertia only becomes worse." $/ d$. at 942 .

$440 \mathrm{Id}$.

441 Id.

442 Michael L. Katz \& Carl Shapiro, Product Introduction with Network Externalities, $40 \mathrm{~J}$. INDUS. ECON. 55, 73 (1992).

443 Katz \& Shapiro, supra note 400, at 106 (observing that new, incompatible standards may emerge despite the presence of network externalities if "consumers . . care more about product attributes than network size"); S.J. Liebowitz \& Stephen E. Margolis, The Fable of the Keys, 33 J.L. \& ECON. 1, 4 (1990) (noting that the "greater the gap in performance between the two standards, ... the more likely that a move to the efficient standard will take place"). 
inefficient technology is potentially a twenty-dollar bill lying on the sidewalk., ${ }^{, 444}$ A sufficiently large difference in value should be sufficient to overcome whatever inertia exists. Even in the absence of such differences in valuation, convertibility or interoperability may limit the inhibition of innovation. ${ }^{445}$ Thus, even if owners of proprietary networks optimize their systems in ways that favor their own applications, the problems stemming from network externalities may be ameliorated if the network owner preserves the ability to run the basic Internet protocols, notwithstanding the fact that the proprietary changes imposed by the system owner may cause those protocols to run less efficiently.

Most importantly for our purposes, explosive growth of the kind that the broadband transport industry is currently undergoing can render the network externalities largely irrelevant. ${ }^{446}$ As Stan Liebowitz and Stephen Margolis have observed, "If a market is growing rapidly, the number of users who have made commitments to any standard is small relative to the number of future users. ${ }^{, 447}$ In such cases, the fact that a particular firm may currently dominate a market is of little consequence. People concerned about lock-in will focus on the size of the network that will exist in the future, not the size of the one that exists today.

It is thus far from clear whether the broadband transport industry is susceptible to becoming locked in to any technology at this point. But the questions will become more complex still. As the next subsection will demonstrate, even when problematic network externalities are present, it is far from clear that standardization and preventing firms from controlling large portions of the network are the best way to solve the problem. On the contrary, the economic literature suggests that such steps might exacerbate these problems further.

\section{b. Proprietary Networks as a Solution to Network Externalities}

Even if a market is subject to network externalities, it is arguable that insisting on standardization will make the problem worse and not better. First, the existence of multiple standards can mitigate many of the

444 Steven N. Kaplan \& J. Mark Ramseyer, Those Japanese Firms with their Disdain for Shareholders: Another Fable for the Academy, 74 WASH. U. L.Q. 403, 405 (1996).

445 Lemley \& McGowan, supra note 436, at 516; Liebowitz \& Margolis, supra note 443, at 5; S.J. Liebowitz \& Stephen E. Margolis, Should Technology Choice Be a Concern of Antitrust Policy, 9 HARV. J.L. \& TECH. 283, 310, 312 (1996).

446 Katz \& Shapiro, supra note 442, at 67, 73 (concluding that exponential market growth effectively prevents excess inertia); Liebowitz \& Margolis, supra note 445, at 292 ("Entrenched incumbents are less entrenched when consumers react to new sales ....").

447 Liebowitz \& Margolis, supra note 445, at 312. 
problems caused by network economic effects. As Michael Katz and Carl Shapiro have noted:

Customer heterogeneity and product differentiation tend to limit tipping and sustain multiple networks. If the rival systems have distinct features sought by certain customers, two or more systems may be able to survive by catering to consumers who care more about product attributes than network size. Here, market equilibrium with multiple incompatible products reflects the social value of variety. ${ }^{448}$

Even in the absence of such customer heterogeneity, permitting proprietary networks to develop may also solve the network externality problem in the way that economics traditionally solves externality and investment problems: by creating well-defined property rights in the resource. The benefit that a person connected to a network receives from other people's adoption decision increases with the percentage of the network that the person controls. Allowing a single firm to control a significant portion of the network would thus allow the firm to internalize more of the benefits of the larger network and give it the incentive to make the investments needed to get the ball rolling. ${ }^{449}$ Indeed, a formal model proposed by Katz and Shapiro indicates that competition among proprietary networks is more likely to lead to the adoption of the socially optimal technology than is competition between non-proprietary networks or competition between a proprietary and a non-proprietary network. ${ }^{450}$ Another of Katz and Shapiro's models found that "the sponsor of a new technology earns greater profits than its entry contributes to social welfare. In other words, markets with network externalities in which new technologies are proprietary exhibit a bias towards new technologies."451 Thus, the suggestion that the existence of proprietary networks tends to retard innovation is far from unassailable.

The presence of firms that occupy a large proportion of a particular network may make that network less susceptible to becoming locked in to any particular technology. Large suppliers and customers of the network

448 Katz \& Shapiro, supra note 400, at 106 (citing Joseph Farrell \& Garth Saloner, Standardization and Variety, 20 ECON. LETTERS 71 (1986)); Liebowitz \& Margolis, supra note 445, at 292 ("Where there are differences in preference regarding alternative standards, coexistence of standards is a likely outcome.").

449 Katz \& Shapiro, supra note 400, at 101; Katz \& Shapiro, Technology Adoption in the Presence of Network Externalities, 94 J. POL. ECON. 822, 825 (1986); S.J. Liebowitz \& Stephen E. Margolis, Are Network Externalities a New Source of Market Failure?, 17 RES. L. ECON. 1, 11, 13 (1995). The fear of being held up after committing to a network might make consumers reluctant to join proprietary networks. Katz and Shapiro describe a number of ways that a network owner can allay such fears. See Katz \& Shapiro, supra note 400, at 104-05, 107.

450 Katz \& Shapiro, supra note 449 , at $825,838-39$.

451 Katz \& Shapiro, supra note 442 , at 73. 
also suffer less from the problems caused by network externalities since their sheer size allows them to be the primary beneficiaries of their own adoption decisions. ${ }^{452}$ As a result, "large buyers are natural candidates to be the network sponsor." ${ }^{\text {,453 }}$ The existence of large players thus represents one way in which the problems of network externalities may be circumvented. Far from being a bane, such firms may be a blessing in disguise.

\section{c. The Ultimate Ambiguity of Vertical Competition}

Finally, even assuming that the network externalities ultimately prove intractable and cause the market to become locked in to particular technologies, it is far from clear whether regulatory intervention would be appropriate. The most complete exposition of this approach appears in the work of Timothy Bresnahan, upon which Lemley and Lessig rely. ${ }^{454}$ Bresnahan's focus is on a market in which the presence of network externalities, strategic entry barriers, and cost asymmetries leads each horizontal layer of a chain of production to become dominated by a single firm. Once these firms achieve dominance over each horizontal layer of the market, the nature of competition changes. Unlike the standard industrial organization framework, under which multiple firms compete at each level, what emerges is a distinctly Schumpeterian (if not Kuhnian) form of competition, ${ }^{45}$ characterized by "long eras of stable buyer-seller relationships," during which players focus on making incremental improvements to the existing platforms, "punctuated by epochs of radical change" resulting from major leaps forward in technology. ${ }^{456}$

Under this theory, Bresnahan regards many of the features that trouble other commentators as nothing more than the result of market equilibrium. For example, the existence of dominant firms is inevitable rather than problematic. As Bresnahan notes, "there will be a client-side dominant firm (whether its name is Microsoft or not)., ${ }^{457}$ In addition, competition in such a market is likely to be characterized by what Bresnahan calls "divided technical leadership," in which firms with similar technical and marketing capabilities attempt to seize control over key

\footnotetext{
452 Katz \& Shapiro, supra note 400 , at 102-03.

453 Jd. at 102.

454 Lemley \& Lessig, supra note 16, at 942 (citing Bresnahan, supra note 396).

455 ThOMAS KuhN, THE STRUCTURE OF A SCIENTIFIC REVOluTION (1962); SCHUMPETER, supra note 416 , at $83-85$.

456 Bresnahan, supra note 396 , at 161 ; see also id. at 169 ("It is not easy to spring customers loose from the network effects of the incumbent's standard, not even for an entrant from an adjacent layer. The most common trigger for an outbreak of epochal vertical competition is a major technological dislocation.").

457 Id. at 194.
} 
platform elements. ${ }^{458}$ Since the different platform elements act as complements, each firm depends, in the short run, on the cooperation of other firms in keeping prices from any one layer from being too high and in making sure that the components remain compatible. ${ }^{459}$ In the long run, however, the companies vie to capture the rents generated by other layers primarily by channeling their energy into inventing new platform components. ${ }^{460}$ Over time, firms can be expected to push constantly at the boundaries between the layers, either by attempting to expand into additional technologies or by advancing their own technology in ways that affect the interfaces between layers. ${ }^{461}$ Thus, although the emergence of proprietary standards and the move to integrate into adjacent markets may well represent an attempt to monopolize a market in an anti-competitive manner, they may also be nothing more than the logical outgrowth of vertical competition. The problem is that it can be very hard to distinguish the two. ${ }^{462}$

It is not at all clear that this model fits the cable modem industry. At present, no firm controls more than sixteen percent of the high-speed broadband market. The current level of competition from DSL and the regulatory constraints limiting the ability of cable operators to increase their geographic footprint make it unlikely that any cable modem operator will be able to achieve dominance in the future. ${ }^{463}$

Even if the theory does apply, it is far from clear what policy makers should do about it. Kevin Werbach somewhat conclusorily asserts that the proper solution is to impose open access and other regulations that help insure that the interfaces between the various layers remain open. ${ }^{464}$ In contrast, Bresnahan is more circumspect about the possible benefits flowing from open access. His analysis suggests only two policy goals. First, policy makers could attempt to encourage dominant firms operating within an "era" to become more innovative. Bresnahan questions the wisdom of this goal since vertical competition already provides substantial incentives for dominant firms to innovate within eras and any failure to do so will have the pro-competitive consequence of hastening the arrival of

458 Id. at 166 . Bresnahan identifies several factors driving dominant firms to attempt to disadvantage other firms operating at a different level. Since the goods sold are typically complementary, each firm depends upon keeping firms at other levels from charging high prices, failing to innovate, and making their products incompatible. In addition, each firm has the incentive to attempt to capture rents generated by another layer. Id.

459 Id.

$460 \quad I d$.

461 Id. at 168 .

462 Id. at 172.

463 See Hazlett \& Bittlingmayer, supra note 386, at 22-23; Lopatka \& Page, supra note 21, at 915.

464 See Werbach, supra note 306. 
the next epoch. ${ }^{465}$ Indeed, regulatory intervention into the interfaces between the various layers might actually hurt competition by locking in the existing relationships in ways that decrease the level of vertical competition.

Second, policy makers could attempt to speed the arrival of the next wave of epochal competition by making it easier for competitors to dislodge the incumbent dominant firm. As a general matter, this would require the government to promote the emergence of a new technology platform. ${ }^{466}$ Bresnahan finds this second policy goal to be problematic for several reasons. Not only does it require users to abandon considerable investments that they have already made in the existing platforms, it also requires policy makers to forecast which new platform should be the winner and do so at an early stage in the technology's development, when such judgments are hardest to make. Even worse, such a decision would likely be made on the basis of proprietary information supplied by the parties themselves. ${ }^{467}$ In addition, Bresnahan warns that policy making in this area tends to be influenced by certain biases that can lead to bad policy results. ${ }^{468}$ As a result, Bresnahan urges policy makers to refrain from intervening and instead to let the forces of the market determine the proper outcome. $^{469}$

Thus, the very model upon which Professors Lemley and Lessig rely does not necessarily support the imposition of open access. Indeed, given the high-rates of growth currently associated with both cable modems and DSL providers, it appears that, for the time being, the broadband transport industry is in the throes of an epochal phase of competition, in which radical technological change is transforming the market. In such a situation, there seems little purpose for the government to attempt to speed the arrival of the next epoch. On the contrary, according to Bresnahan, the real danger arises from the possibility that the government would be thrust into the position of picking technological winners and losers. Unfortunately, the current state of asymmetrical regulation, in which DSL providers are subject to significantly greater regulatory burdens than cable modem providers, makes it increasingly likely that the government will assume this role. Confronted with these dangers, I would heed Bresnahan's advice and allow the market to sort out the relative merits of these two technologies. I thus agree with Lemley and Lessig's call for regulatory symmetry in the broadband industry. ${ }^{470}$ Where we differ is that Lemley

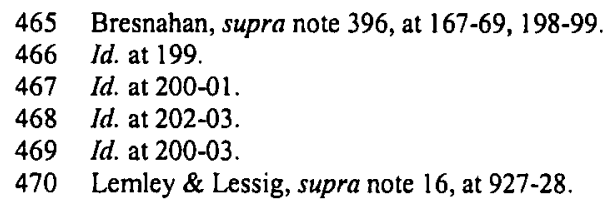


and Lessig would impose access requirements on both DSL and cable modems, whereas the symmetry I envision is one in which neither industry is subject to access regulation.

\section{Obstacles to an Integrated Approach to Vertical Media Regulation}

Many, if not most, of the economic principles I have described are far from new. Quite the contrary, many of the ideas on which I rely represent some of the most firmly established principles of competition policy. What then explains the failure to appreciate the relevance of the various economic principles? Three ideas come to mind.

\section{A. Misplaced Focus on Technological Differences Rather than Functional Similarities}

The most salient mistake identified by the foregoing analysis is the tendency to treat each technology as if it were a universe unto itself. Failing to recognize the emergence of cable networks as competitors to the broadcast networks, DBS as a competitor to cable, and DSL as a competitor to cable modem service tends to exaggerate the dominance of the supposedly dominant technology.

The first problem stems from a misconception about the important role that the existence of substitutes can play in dissipating market power. Courts long exhibited a tendency to treat each technology as if it were a universe unto itself. ${ }^{471}$ For example, courts hearing tying cases have historically presumed that the exclusive right to use a technology granted by a patent necessarily gave rise to market power. ${ }^{42}$ This presumption only makes sense if each technology is regarded as occupying a separate market. Courts and commentators have become increasingly aware that exclusive control over a particular technology confers no monopoly power when substitutes for that technology exist. ${ }^{473}$ In such cases, any attempt to

471 See generally HoVENKAMP, supra note 52, §3.9d, at 141-42, § 10.3c, at 400-01.

472 See, e.g., Jefferson Parish Hosp. Dist. No. 2 v. Hyde, 466 U.S. 2, 16 (1984) ("II]f the government has granted the seller a patent or similar monopoly over a product, it is fair to presume that the inability to buy the product elsewhere gives the seller market power."); United States Steel Corp. v. Fortner Enters., 429 U.S. 610, 619 (1977) ("Thus, the statutory grant of a patent monopoly ... represented tying product[s] that the Court regarded as sufficiently unique to give rise to a presumption of economic power."); United States v. Loew's Inc., 371 U.S. 38, 45, 45 n.4 (1962) ("The requisite economic power is presumed when the tying product is patented ...."; "[W] hen the tying product is patented ... sufficiency of economic power is presumed.").

473 Jefferson Parish, 466 U.S. at 37 n.7 (O'Connor, J., concurring) ("A common misconception has been that a patent . . . suffice[s] to demonstrate market power. . . . [A] patent holder has no market power in any relevant sense if there are close substitutes for the patented products."); $N$. Pac. Ry. Co. v. United States, 356 U.S. 1, 10 n.8 (1958) ("Of course it is common knowledge that a patent does not always confer a monopoly over a particular commodity."); Abbott Labs. v. Brennan, 952 F.2d 1346, 1354 (Fed. Cir. 1991) ("A patent does not of itself establish a presumption of market 
extract additional benefits will simply induce customers and suppliers to turn to the alternative technology instead.

Even if aware of this problem, policy makers at the FCC remain constrained by the technological approach embodied in the structure of the Communications Act of 1934 itself. As Kevin Werbach has pointed out, the Act divides the communications market horizontally, with each major technology being governed by a separate chapter in Title 47 of the U.S. Code and a separate bureau within the FCC. ${ }^{474}$ As a result, each regulatory decision is statutorily and bureaucratically programmed to address a single technology. ${ }^{475}$ This technological division could provide a satisfactory basis for policy making only so long as the various technologies did not act as substitutes for one another, since the FCC could focus on each medium in isolation and could craft solutions tailored to the particular type of communications conveyed, as well as to the economics underlying the means of transmission. For example, the regulatory model developed for telephony combined the natural monopoly economics of wire-based communications with the relatively uncomplicated free speech implications of person-to-person communications. The logical response was common carriage obligations combined with rate regulation. Conversely, with respect to broadcasting, the FCC attempted to craft a solution suited to the interference-related problems of spectrum-based communications, as well as the unique economic and First Amendment issues raised by mass media products, which tend to be differentiated and non-rivalrous and which tend to play a more important role in the political process.

The emergence of cable television began to cause this tidy division to unravel. Cable allowed mass media programming to reach consumers via the technology previously dedicated to personal communications. As a result, neither the telephony model nor the broadcast model could serve as an adequate basis for regulation. What followed was thirty years of

power in the antitrust sense."), cert. denied, 505 U.S. 1205 (1992); POSNER, supra note 69, at 172 n.3 ("A patent is actually a poor proxy for monopoly power .... (Some patents confer no monopoly power at all... ."); Kenneth W. Dam, The Economic Underpinnings of Patent Law, $23 \mathrm{~J}$. LEGAL STUD. 247, 249-50 (1994) ("[I]t became conventional to say that a patent is a monopoly. Nonetheless, it is readily apparent that the right to exclude another from 'manufacture, use, and sale' may give no significant market power ... ."); Edmund W. Kitch, Patents: Monopolies or Property Rights?, 8 RES. L. \& ECON. 31, 31 (1986) ("Since competitive forces which act upon a patent holder are readily identifiable, the patent holder cannot be assumed to have monopoly power."). Consistent with this insight, Congress amended the patent statute in 1988 to make clear that patent tying applies only when the patents have been shown to confer monopoly power. 35 U.S.C. $\$ 271$ (d)(5) (1994).

474 For example, telephony is governed by Title II of the Communications Act and is regulated by the Common Carrier Bureau. Broadcasting is governed by Title III of the Act and is regulated by the Mass Media Bureau. Cable television is governed by Title VI of the Act and is regulated by the Cable Services Bureau.

475 Werbach, supra note 306, at 2. 
Table X.

\begin{tabular}{|c|c|c|c|}
\hline & & \multicolumn{2}{|c|}{ Type of Speech Conveyed } \\
\hline & & $\begin{array}{c}\text { Personal } \\
\text { Communications }\end{array}$ & $\begin{array}{c}\text { Mass } \\
\text { Communications }\end{array}$ \\
\hline Means of & Wire-Based & Telephony & \\
\hline Transmission & Spectrum-Based & & Broadcasting \\
\hline
\end{tabular}

confusion, as both the FCC and the courts attempted first to fit cable into one of the existing regulatory boxes established by the Communications Act and then struggled with the limits imposed by the application of categories developed with another technology in mind. ${ }^{476}$ But the problems raised by cable were more profound than simply finding a new regulatory approach designed for the underlying characteristics of a new technology. For the first time, policy makers had to design a regulatory scheme that took into account not only the unique aspects of a new medium, but also the fact that the new medium could act as a substitute for another medium. Thus, the FCC could no longer treat each medium as a separate regulatory problem. Any solution would have to confront the more difficult problem of the interaction between two different media that each possessed different strengths. ${ }^{477}$

The results can perhaps most charitably be described as chaotic. Many of the FCC's early attempts to regulate the relationship between the broadcast and cable industries were either struck down by the courts ${ }^{478}$ or abandoned. ${ }^{479}$ In the end, the major policy disputes were not resolved until

476 At first, the FCC denied that cable fell into any of the conceptual categories established by the Communications Act. See Frontier Broad. Co., 24 F.C.C. 251 (1958) (Memorandum Opinion and Order). It soon reversed itself and asserted jurisdiction over cable on the basis of its authority to regulate the television industry. See Carter Mountain Transmission Corp., 32 F.C.C. 459, 464-65 (1962) (Decision). The Supreme Court eventually upheld the FCC's jurisdiction to act in United States v. Southwestern Cable Co., 392 U.S. 157 (1968). Placing cable within the broadcast regulatory scheme only raised additional complications, however. The natural monopoly characteristics of cable led the FCC to attempt to mandate leased access. The Supreme Court overtumed the FCC's leased access requirement on the grounds that the title of the Communications Act governing broadcasting forbade the imposition of common carriage obligations. See FCC v. Midwest Video Corp., 440 U.S. 689 (1979).

477 See Werbach, supra note 306 , at 10.

478 Most significantly, the courts struck down the FCC's earliest attempts to impose must carry requirements. See Century Communications Corp. v. FCC, 835 F.2d 292 (D.C. Cir. 1987), cert. denied, 486 U.S. 1032 (1988); Quincy Cable TV, Inc. v. FCC, 768 F.2d 1434 (D.C. Cir. 1985), cert. denied, 476 U.S. 1169 (1986). Courts also struck down the FCC's attempt to prohibit premium channels as well as the "anti-siphoning rules" designed to prevent movies and other programs that previously would have been shown on broadcast television from migrating to pay cable. See Home Box Office, Inc. v. FCC, 567 F.2d 9 (D.C. Cir.) (per curiam), cert. denied, 434 U.S. 829 (1977)

479 For example, in 1974 the FCC repealed a regulation attempting to introduce parity between broadcasting and cable by requiring cable operators to originate local programming. See Amendment of Part 76, Subpart G, of the Comm'n's Rules and Regulations Relative to Program Origination by Cable Television Syss; and Inquiry into the Dev. of Cable Casting Services to 
Congress enacted major cable legislation in 1984 and 1992 that established a separate title that largely prescribed the regulatory regime that would be applied. ${ }^{480}$ The enactment of those statutes did not end the confusion and the disputes over the proper scope of cable policy, however. Although the Acts largely resolved the major jurisdictional and substantive issues over cable regulation, they simply shifted the basis for dispute towards the First Amendment. $^{481}$

The arrival of wireless telephony completed the collapse of this neat regulatory division. The identity between the means of transmission and the type of speech transmitted disappeared altogether, as both mass market and private speech could be conveyed through either means of transmission.

Table XI.

\begin{tabular}{|c|c|c|c|}
\hline & \multicolumn{2}{|c|}{ Type of Speech Conveyed } \\
\hline & & $\begin{array}{c}\text { Personal } \\
\text { Communications }\end{array}$ & $\begin{array}{c}\text { Mass } \\
\text { Communications }\end{array}$ \\
\hline Means of & Wire-Based & Telephony & Cable \\
\hline Transmission & Spectrum-Based & Wireless & Broadcasting \\
\hline
\end{tabular}

Although the Telecommunications Act was trumpeted as a way to end the "balkanization" of communications technologies, ${ }^{482}$ it did little to dislodge the horizontal model of communications policy. ${ }^{483}$ It left the existing technologically-oriented structure of the Communications Act firmly in place. Even worse, it failed to take seriously the prospect that

Formulate Regulatory Policy and Rulemaking, 49 F.C.C.2d 1090 (1974) (Report and Order). In addition, the FCC later abolished rules in place since the mid-1960s that prevented most cable operators from importing broadcast signals from other cities. See Cable Television Syndicated Program Exclusivity Rules, 79 F.C.C.2d 663 (1980) (Report and Order) (repealing the prohibition on distant signal importation), aff'd sub nom. Malrite T.V. of N.Y. v. FCC, 652 F.2d 1140 (2d Cir.), cert. denied, 454 U.S. 1143 (1982); Amendment of Subpart D of Part 76 of the Comm'n's Rules and Regulations with Respect to Selection of Television Signals for Cable Television Carriage (Leapfrog Rules): $\$ \S 76.59(\mathrm{~b})(1)$ and (2), 76.61 (b)(1) and (2), and 76.63, 57 F.C.C.2d 625, 645 (1976) (Report and Order) (repealing the "anti-leapfrogging" rules that required those cable operators who were permitted to import distant signals do so only from adjacent cities).

480 Cable Television Consumer Protection and Competition Act of 1992, Pub. L. No. $102-$ 385, 106 Stat. 1460; Cable Communications Policy Act of 1984, Pub. L. No. 98-549, 98 Stat. 2779.

481 See, e.g., United States v. Playboy Entm't Group, Inc., 529 U.S. 803 (2000); Tumer Broad. Sys., Inc. v. FCC, 520 U.S. 180 (1997); Denver Area Educ. Telecomms. Consortium, Inc. v. FCC, 518 U.S. 727 (1996); Turner Broad. Sys., Inc. v. FCC, 512 U.S. 622 (1994); Time Warner Entm't Co. v. FCC, 240 F.3d 1126 (D.C. Cir.), cert. denied, 122 S. Ct. 644 (2001); Time Warner Entm't Co. v. U.S., 211 F.3d 1313 (D.C. Cir. 2000), cert. denied, 531 U.S. 1183 (2001); Time Warner Entm't Co. v. FCC, 93 F.3d 957 (D.C. Cir. 1996); Time Wamer Entm't Co. v. FCC, 56 F.3d 151 (D.C. Cir. 1995), cert. denied, 516 U.S. 1112 (1996).

482 See Krattenmaker, supra note 200, at 130, 156 (1996).

483 Werbach, supra note 306 , at 3. 
competition could arise from the same type of speech transmitted via different technology. ${ }^{484}$ Although the recent reorganization of the FCC along more functional lines is a welcome innovation, it does nothing to change the balkanized structure of the underlying substantive mandates that the FCC is charged with enforcing.

These problems are starting to plague the Internet as well. ${ }^{485}$ For example, the proper categorization of cable modem service remains elusive. At first, commentators tended to believe that it should be classified as a cable service. ${ }^{486} \mathrm{~A}$ pair of recent judicial decisions has classified cable modems as a telecommunications service. ${ }^{487} \mathrm{~A}$ recent Supreme Court decision declined to resolve the issue. ${ }^{488}$ Hopefully, the FCC will resolve the issue in the near future.

The problem, moreover, is about to get much worse. The impending shift of all networks to packet-switched technologies promises to cause all of the distinctions based on the means of conveyance and the type of speech conveyed to collapse entirely. Once all communications are reduced to bits and bytes, they can be transmitted via any technology. Once this occurs, the distinctions drawn in the columns and the rows represented in Table XI will no longer remain coherent as a regulatory approach. Even more importantly, the shift to packet-switched, dataoriented networks will cause all the different means of transmission to become substitutes for one another. The logical step is to adopt what Kevin Werbach has termed a "layered approach, ${ }^{, 489}$ which discards the current policy of technological compartmentalization in favor of treating the retail, wholesale, and manufacturing segments of the industry.

At this point, however, the existing statutory approach remains firmly entrenched, and as the recent experience with financial services reform reveals, any attempt to revise it promises to be time-consuming and

484 For example, when establishing the conditions under which a local telephone company faces sufficient competition to justify releasing it from its regulatory obligations, the Telecommunications Act of 1996 in effect disregarded the possibility of competition from wireless telephony. See 47 U.S.C. $\$ 271$ (c)(1)(A) (Supp. III 1997) ("For the purpose of this subparagraph, services provided pursuant to subpart K of part 22 of the Commission's regulations (47 C.F.R. 22.901 et seq.) shall not be considered to be telephone exchange services."). The problems with this approach are readily apparent in an era during which many cellular providers are encouraging customers to terminate their landline service and to regard their wireless phones as the only phone they will ever need.

485 For an excellent review and analysis of these issues, see Chen, supra note 13.

486 Shelanski, supra note 25, at 740-41; Speta, Handicapping, supra note 21, at 71-75; Shih, supra note 390 , at 801 .

487 AT\&T Corp. v. City of Portland, 216 F.3d 871, 878 (9th Cir. 2000); MediaOne Group, Inc. v. County of Henrico, 257 F.3d 356, 364-65 (4th Cir. 2001).

488 Nat'l Cable \& Telecomms. Ass'n v. Gulf Power Co., 122 S. Ct. 782, 788 (2002). The lower court had held that cable modem services were neither cable services nor telecommunications services. See Gulf Power Co. v. FCC, 208 F.3d 1263, 1276 (11th Cir. 2000), rev'd on other grounds sub nom. Nat'l Cable \& Telecomms. Ass'n v. Gulf Power Co., 122 S. Ct. 782 (2002).

489 Werbach, supra note 306, at 9-13. 
heavily politicized. We thus appear to be stuck with the statutory structure we now have, and the regulatory and institutional framework resulting from that structure makes any revolutionary shifts in approach all but impossible. So long as the underlying statutory framework remains in place, there remains a danger that the FCC will continue to analyze markets on a technology-by-technology basis without taking into account the extent to which services serve as substitutes for one another. ${ }^{490}$

\section{B. Lack of a Comprehensive Approach to the Economics of Vertical Integration}

Another key explanation is that policy makers and commentators are all too often incompletely versed in the basic economic insights of the past few decades of scholarship on vertical integration. The dangers of vertical integration seem quite intuitive: It seems obvious that a merger between the nation's largest ISP and its second largest cable operator would threaten competition. In fact, the Supreme Court accepted both leveraging and foreclosure as rationales for decades. Furthermore, there is a tremendous temptation to look at the real problems facing the competitors who are being shut out and forget that antitrust laws exist to benefit competition, not competitors. What the last half-century of economic theory has demonstrated is that, while vertical integration can harm competition, circumstances also exist in which vertical integration can promote efficiency.

In addition, antitrust and regulated industries law has done a relatively poor job of developing a sophisticated understanding of vertical integration. Both antitrust and regulatory policy are largely geared towards static efficiency concerns of price and quantity and consumer choice in the here and now. They seem badly designed to take into account dynamic efficiency considerations, such as the effect that compelled access has on incentives to invest and innovate. In addition, the law has tended not to give potential transaction cost efficiencies proper consideration. A review of the leading communications law and antitrust textbooks reveals that discussions of transaction cost considerations tend to be limited to brief descriptions of the possibility of free riding on pre-sale services. ${ }^{491}$ The

490 See Shelanski, supra note 25 , at 741 (noting that the need to place DSL and cable modems in particular regulatory boxes may lead the FCC to ignore any rivalry that may exist between those services).

491 For the discussions appearing in the leading communications law textbooks, see STUART Minor Benjamin, Douglas Gary LiCHTMan, \& Howard A. SHELANSKI, TeleCOMMUNiCATIONS LAW AND POLICY 293, 301 (2001); and MICHAEL BOTEIN, REgULATION OF THE ELECTRONIC MASS MEDIA 267, 285 (3d ed. 1998). For the discussions appearing in the leading antitrust textbooks, see PHILliP AREEDA \& LOUIS KAPLOW, ANTITRUST ANALYSIS: PROBLEMS, TEXT, AND CASES 614-15 (5th ed. 1997); CHARLES J. GOETZ \& FRED S. MCCHESNEY, ANTITRUST LAW: INTERPRETATION AND IMPLEMENTATION 464-66 (1998); MILTON HANDLER ET AL., CASES AND MATERIALS ON TRADE 
economic literature on vertical integration does not fare much better. In fact, the formal models of vertical integration routinely fail to take efficiencies into account. ${ }^{492}$

Finally, a proper understanding of vertical integration depends as much on the interaction between the various economic principles as it does on the principles themselves. Viewed in this manner, the nature of the disagreement between Professors Lemley and Lessig and Professor Speta over the dangers of monopoly leveraging begins to make sense. Professors Lemley and Lessig argue that Professor Speta's critique of leveraging suffers from a large prediction problem since cable modem providers are clearly engaging in vertical integration. ${ }^{493}$ It is true that, if viewed in isolation, the critique of leveraging would suggest that vertical integration would never occur. The conclusion changes dramatically when all of vertical integration theory is viewed as an integrated whole, since the existence of welfare-enhancing efficiencies provides a strong explanation of why vertical integration might be economically beneficial. Thus reconstructed, the argument is not that the critique of leveraging demonstrates that vertical integration is never profitable and thus never undertaken. A more comprehensive view of the vertical integration literature reveals that it is highly unlikely that vertical integration in the markets considered by this Article is being driven by anti-competitive motives. The fact that vertical integration is in fact occurring tends instead to suggest the existence of efficiencies from vertical integration. Thus, the supposed prediction problem that Professors Lemley and Lessig have identified simply disappears.

\section{Misconceived Analogies to Previous Legacy Monopolies}

Lastly, there is also a temptation for policy makers and commentators to draw inspiration from old regulatory patterns and models. The FCC's long history with rate regulation and common carriage obligations in both telephony and cable television, along with its perceived mandate to open

REgulation 582-84 (4th ed. 1997); THOMAS D. MORGAN, CASES AND MATERIALS ON MODERN ANTITRUST LAW AND ITS ORIGINS 604-06 (2d ed. 2001); and E. THOMAS SUllivan \& HERBERT Hovenkamp, antitrust Law, POlicy and Procedure: CaSes, Materials, Problems 420-21 (4th ed. 1999). Note that none of these texts contain an index entry for "transaction costs." Regulated industry textbooks provide somewhat more extended discussions of these issues. See JEFFREY L. harrison, Thomas D. Morgan, \& Paul R. Verkuil, Regulation and Deregulation: Cases AND MATERIALS 191-219 (1997); RICHARD J. PIERCE, JR., ECONOMIC REGULATION 261-74 (1994); SIDNEY A. SHAPIRO \& JOSEPH P. TOMAIN, REgUlATORY LAW AND POLICY: CASES AND MATERIALS 405-08 (2d ed. 1998). at 593 .

492 See Klass \& Salinger, supra note 128 , at $679,681-83$; Snyder \& Kauper, supra note 135 ,

493 Lemley \& Lessig, supra note 16, at $948,951$. 
markets, ${ }^{494}$ appear to lead to the imposition of compelled access on nondiscriminatory terms. It is all too easy to see a lot of Ma Bell in the modern incarnation of $\mathrm{Ma} \mathrm{Cable}{ }^{495}$

The comparison to AT\&T, however, is inapt. As noted earlier, compelled access makes sense only if the industry being regulated is truly a natural monopoly that has already entered its mature stage in which the technology has already been largely deployed and incremental revenue and customer growth is relatively slow. Regulatory solutions are easier to manage, in that regulators can predict the future with greater confidence. Investment incentives also play a lesser role. Such an approach, however, has little applicability to industries like high-speed broadband, which are undergoing explosive growth and technological change. In such industries, firms do not compete over switching over a fixed number of existing customers. Instead, firms engage in vigorous competition to capture new customers. In addition, investment incentives play a more central role in regulatory policy when a growing industry is involved, and regulators confront the nearly intractable task of having to predict which technologies are likely to emerge as superior. As a result, policy makers should think long and hard before extending regulatory solutions developed for mature markets to an industry that is growing rapidly at a time when the growing competition among communications channels that had previously been separate is beginning to erode the natural monopoly characteristics of all media.

Not only are there dramatic differences in the industries being regulated; there are also drastic differences in the size and scope of the two organizations being compared. There can be little question that AT\&T was able to use its absolute control over particular vertical levels of competition to squelch competition in other levels. ${ }^{496}$ There is a key difference between the two situations, however. Unlike the old AT\&T, which controlled the entire national market for long distance, local service, and telephone equipment, the current players in the telecommunications markets control only a limited portion of the national market. In fact, the largest MSO controls only seventeen percent of the national market for MVPDs and sixteen percent of the broadband transport market; the second

494 See Shelanski, supra note 25 , at 739 .

495 See Lemley \& Lessig, supra note 16, at 936-38. The specter of Ma Cable was largely dissipated by AT\&T's recent announcement that it was selling its cable properties to Comcast. See Solomon \& Frank, supra note 229.

496 For example, from 1900 to 1930 , AT\&T was able to use the market power provided by its long distance patents to quash the emergence of competitive providers of local telephone service. See Roger G. Noll \& Bruce M. Owen, The Anticompetitive Uses of Regulation: United States v. AT\&T, in THE ANTITRUST REVOLUTION 290, 292-93 (John E. Kwoka, Jr. \& Lawrence J. White eds., 1989). Later on, it was able to use its monopoly control over the nation's local telephone service to stifle the arrival of competition in the long distance markets. Id. at 302-06. 
largest controls only fifteen percent of both of those markets. As the D.C. Circuit recently held, given that the FCC has concluded that a new cable network need only reach twenty percent of the market to achieve minimum viable scale, the argument that either of these companies was in a position to unilaterally harm competition in the market for television networks is simply not credible. ${ }^{497}$

In addition, it is far from clear that the FCC's previous efforts to dislodge legacy monopolies should properly be viewed as success models. Although there are clearly some examples in which the FCC served to promote competition in telephone service, ${ }^{498}$ other commentators have been struck by the extent to which AT\&T was able to use the regulatory process to thwart competition. ${ }^{499}$ Indeed, both Chicago ${ }^{500}$ and PostChicago theorists ${ }^{501}$ agree that regulation can be a way to impose cost disadvantages on rivals and to create barriers to entry. These insights have been confirmed by a vibrant empirical literature identifying a wide variety of cases in which various forms of regulation were used precisely in this manner. ${ }^{502}$

A review of the history of mass media regulation reveals a long legacy of policies that frustrated the emergence of competition. With respect to broadcasting, even though policy makers had long regarded network dominance as one of the central problems plaguing the broadcast industry, subsequent analyses have shown that the maintenance of that dominance was almost entirely the result of regulatory policy. Indeed, the FCC had rejected a number of policy alternatives that would have allowed more networks to emerge. ${ }^{503}$ Even worse, those measures adopted to combat network dominance had the perverse effect of entrenching the

497 Time Wamer Entm't Co. v. FCC, 240 F.3d 1126, $1130-39$ (D.C. Cir.), cert. denied, 122 S. Ct. 644 (2001).

498 See, e.g., Use of the Carterfone Device, 13 F.C.C.2d 420, 424 (1968) (Decision).

499 E.g., Noll \& Owen, supra note 496; Kearney \& Merrill, supra note 22, at 1367.

500 See BORK, supra note 70, at 159, 347-64; Gary S. Becker, A Theory of Competition Among Pressure Groups for Political Influence, 98 Q.J. ECON. 371 (1983); Sam Peltzman, Toward a More General Theory of Regulation, 19 J.L. \& ECON. 211 (1976); Richard Posner, Taxation by Regulation, 2 BELL J. ECON. \& MGMT. SCI. 22 (1971); Richard Posner, Theories of Regulation, 5 BELL J. ECON. \& MGMT. SCI. 335 (1974); George J. Stigler, The Theory of Economic Regulation, 2 BELL J. ECON. \& MGMT. SCI. 3 (1971).

501 See Hovenkamp, After Chicago, supra note 128, at 276-77, 279; Salop \& Scheffman, supra note 131, at 268, 268-69; Williamson, supra note 118, at 293.

502 See Robert E. McCormick, The Strategic Use of Regulation: A Review of the Literature, in THE POLITICAL ECONOMY OF REGULATION 13, 18-25 (1984) (providing an excellent review of the early literature).

503 The central problem was the FCC's decision to allocate only three television stations to most markets. This decision all but foreordained that only three broadcast networks would develop. See NeW TEleVISION NETWORKS, supra note 28, at 67-81, 488-9; MisREGULATING TELEVISION, supra note 32, at 12-16; Henry Geller, A Modest Proposal for Modest Reform of the Federal Communications Commission, 63 GEO. L.J. 705, $707-18$ (1975); Thomas L. Schuessler, Structural Barriers to the Entry of Additional Television Networks: The Federal Communications Commission's Spectrum Management Policies, 54 S. CAL. L. REV. 875 (1981). 
existing broadcast networks, since steps taken to limit the profitability of network operations also served to make entry of new networks more difficult. ${ }^{504}$

The history of cable regulation is just as troubling. Even though cable television represented an obvious way to introduce greater competition in television programming, the FCC's initial response was to attempt to suppress its growth. ${ }^{505}$ Once cable became established, the central policy problem became cable's supposed position as a natural monopoly. As a result, one might have expected policy makers to embrace DBS when it began to emerge as an alternative to cable. Instead, policy makers established a regime that protected both broadcasting and cable from the emergence of this new rival by making it all but impossible for DBS to carry programming from the major broadcast networks in most areas. ${ }^{506}$ Even though Congress took a range of fairly drastic steps to curb the monopoly that cable television held over local markets, ${ }^{507}$ it did not revisit this fundamental decision to deny DBS the ability to carry local broadcast programming for more than a decade ${ }^{508}$ Thus, despite the fact that the central policy dilemma posed by cable was its tendency towards local monopoly, policy makers consistently adopted policies that failed to encourage the development of alternative video technologies.

Even the mere threat of access regulation can stifle the emergence of competition in an emerging industry characterized by large, up-front investments. Regulators have incentives to attempt to force firms to price at marginal cost after the initial fixed costs have been sunk that are quite similar to the incentives faced by private firms. While firms can use vertical integration or vertical contractual restraints to manage the possibility of such opportunistic behavior by business partners, the impossibility of merging with the government and the near-impossibility of estopping the government from imposing access regulation render the

504 See NEW TELEVISION NETWORKS, supra note 28, at 521-22; Chen, supra note 21, at 1454-56.

505 See, e.g., Stanley M. Besen, The Economics of the Cable Television "Consensus", 17 J.L. \& ECON. 39 (1974); Rolla Edward Park, The Growth of Cable TV and Its Probable Impact on Overthe-Air Broadcasting, 61 AM. ECON. REV. 69 (Papers \& Proc. 1971). As FCC Chairman Dean Burch candidly admitted, the FCC had interpreted its public interest mandate to include "the short-term protectionism for over-the-air broadcasting" against incursions by cable television. See Besen, supra, at 41 .

506 See 17 U.S.C. $\$ 119(\mathrm{a})(2)(\mathrm{B})$ (1994) (limiting the compulsory copyright license for satellite broadcasters' retransmission of broadcast programming to areas not already served by local broadcasters). In so doing, Congress explicitly acknowledged that the primary purpose of this restriction was to protect local broadcasters. See H.R. REP. No. 100-887, pt.1, at 8 (1988), reprinted in 1988 U.S.C.C.A.N. 5577, 5617 (recognizing that the original Satellite Home Viewer Act of 1988 was intended to protect the existing "network/affiliate distribution system").

507 See, e.g., Cable Television Consumer Protection and Competition Act of 1992, Pub. L. No. 102-385, 106 Stat. 1460.

508 See supra note 224 and accompanying text. 
risk of regulatory opportunism essentially intractable. ${ }^{509}$ The inability to render these risks more manageable will deter firms from making such fixed cost investments in the first instance.

Policy makers would thus do well to follow the advice of a recent study published by a staff member of the FCC's Office of Plans and Policy. This study cautioned against knee-jerk extension of the regimes devised to regulate the existing legacy monopolies to new technologies, such as high-speed broadband. On the contrary, the study concluded that the better policy response would be to deregulate the existing legacy monopolies as technologies converge. ${ }^{510}$

\section{Conclusion}

The history of vertical integration policy has been dominated by a search for simple policy inferences. The Harvard School's initial advocacy of what amounted to per se illegality gave rise to the Chicago School's call for a rule of reason approach to vertical integration. The Chicago School's eventual rejection of the rule of reason in favor of per se legality, in turn, spawned the post-Chicago reaction demonstrating that vertical integration can under some circumstances have anti-competitive effects. There can be no question that post-Chicago scholarship is greatly enhancing our understanding of the economics of vertical integration and is likely to make additional contributions in the future.

The problem is that many advocates are all too tempted to try to turn the post-Chicago literature into a basis for returning to a world in which vertical integration is once again regarded as per se illegal. As is the case with most economic problems, the economics of vertical integration are not susceptible to the type of simple policy inferences needed to support broad generalizations. Instead, the economic literature suggests that whether a particular instance of vertical integration harms competition is likely to depend on a fairly refined set of factual predicates. As such, the problems of vertical integration appear to be poorly suited to the type of per se resolution associated with the categorical approach inevitably associated with regulatory enactments. This is not to say that vertical regulation should be immune from governmental scrutiny. This position simply acknowledges that, to the extent that anti-competitive dangers exist, they are better addressed in a forum, such as an antitrust court, that can evaluate each situation on the basis of its individual facts.

509 See J. Gregory Sidak \& Daniel F. Spulber, Deregulation and Managed Competition in Network Industries, 15 YALE J. ON REG. 117, 122-25 (1998); see also Goldberg, supra note 114, at 432-36 (noting that market participants seek some assurance regarding the long-term availability of the market before investing).

510 OXMAN, supra note 7 , at $24-25$. 
Moreover, noting that the anti-competitive impact of vertical integration turns on the facts of specific cases does not mean that we cannot draw some generalizations about the circumstances under which such anti-competitive impacts are most likely to occur. As I have described above, there is a broad economic consensus that spans both the Chicago School and post-Chicago literature confirming the notion that vertical integration is unlikely to harm static efficiency unless certain structural preconditions are met. Specifically, vertical integration raises few anticompetitive concerns absent concentration and barriers to entry in the relevant markets. In addition, both approaches acknowledge that efficiency considerations might justify vertical integration even when these structural preconditions have been met. An application of this analytical framework to the broadcast television, cable television, and cable modem industries reveals that vertical integration in these industries is too unlikely to harm competition to justify broad regulatory prohibition.

Analyzing these markets in terms of dynamic efficiency only serves to reinforce this core conclusion. Regulatory restrictions on vertical integration harm dynamic efficiency by rescuing competitors from having to invest in developing alternative sources of supply that would ultimately break whatever monopoly bottleneck power that represents the true source of the anti-competitive harms. In addition, prohibitions on vertical integration can deter new entry in another way. By preventing firms from realizing available efficiencies, such regulations reduce the profitability of all operations. As commentators have noted, the fact that such a burden will weigh especially heavily on new entrants may lead such regulation to have the perverse effect of deterring entry, thereby entrenching whatever market power already possessed by incumbent firms.

Dynamic efficiency, of course, depends on innovation as well as investment incentives, and one can easily identify approaches that suggest that large integrated enterprises and considerations such as network economics can prevent the market from achieving an efficient level of innovation. A close review of the full range of the economic literature on innovation reveals a much more ambiguous story. Although some studies suggest that standardization, concentration, and network externalities can reduce innovation below welfare maximizing levels, other studies conclude that those same factors may play essential roles in ensuring that an appropriate amount of innovation does in fact occur. Thus, in the end, it appears that innovation-related theories do not provide a clear basis for adopting a skeptical stance towards vertical integration. The fact remains that, notwithstanding the many arguments to the contrary, vertical integration is not sufficiently likely to threaten competition as to justify imposing a categorical, regulatory prohibition of the practice. Such a result 
Vertical Integration and Media Regulation in the New Economy would be tantamount to return to the world of per se illegality that typified the now discredited economic thinking of the 1950s and 1960s. 
Appendix A. Broadcast and Cable Networks Ratings as of March 2001

\begin{tabular}{|c|c|c|c|}
\hline Company/Network & Rating & Company/Network & Rating \\
\hline Viacom & & AOL Time Warner & \\
\hline CBS & 8.6 & WB & 2.6 \\
\hline UPN & 2.5 & TBS Superstation & 1.9 \\
\hline Nickelodeon & 1.6 & TNT & 1.6 \\
\hline TNN & 1.1 & Cartoon Network & 0.8 \\
\hline MTV & 0.9 & $\mathrm{CNN}$ & 0.7 \\
\hline TV Land & 0.7 & $W_{G N}{ }^{1}$ & 0.6 \\
\hline Comedy Central $^{2}$ & 0.7 & Total & 8.2 \\
\hline $\mathrm{VHI}$ & 0.5 & & \\
\hline \multirow[t]{2}{*}{ Total } & 16.6 & Liberty Media & \\
\hline & & Discovery Channel $^{6}$ & 1.3 \\
\hline Walt Disney Co. & & $\mathrm{TLC}^{6}$ & 1.0 \\
\hline $\mathrm{ABC}$ & 8.7 & Court TV & 0.6 \\
\hline Lifetime ${ }^{3}$ & 2.0 & Travel Channel & 0.5 \\
\hline Disney Channel & 1.5 & Game Show Network & 0.5 \\
\hline$A \& E^{4}$ & 1.4 & Animal Planet ${ }^{6}$ & 0.5 \\
\hline History Channel ${ }^{4}$ & 0.9 & Odyssey Channel & 0.4 \\
\hline ESPN & 0.9 & Total & $\overline{4.8}$ \\
\hline Toon Disney & 0.5 & & \\
\hline ESPN2 & 0.4 & USA Networks ${ }^{8}$ & \\
\hline \multirow[t]{2}{*}{ Total } & 16.3 & USA Network & 1.9 \\
\hline & & Sci-Fi Channel & 0.8 \\
\hline News Corp. & & Total & 2.7 \\
\hline Fox & 6.3 & & \\
\hline Fox News Channel & 0.9 & Cablevision Systems & \\
\hline FX & 0.8 & $\mathrm{AMC}$ & 0.7 \\
\hline Fox Family Channel & 0.7 & Bravo & 0.4 \\
\hline $\mathrm{BET}^{5}$ & 0.6 & Total & 1.1 \\
\hline TV Guide Channel & 0.6 & & \\
\hline \multirow[t]{2}{*}{ Total } & 9.9 & E.W. Scripps Co. & \\
\hline & & HGTV & 0.7 \\
\hline General Electric & & Food Network & 0.4 \\
\hline NBC & 8.1 & Total & 1.1 \\
\hline $\mathrm{PaxTV}^{7}$ & 0.9 & & \\
\hline MSNBC & 0.4 & Landmark Communications & \\
\hline $\mathrm{CNBC}$ & 0.4 & Weather Channel & 0.3 \\
\hline Total & 9.8 & & \\
\hline
\end{tabular}

1 WGN is owned by the Tribune Company, which in turn owns a $25 \%$ stake in WB. Although WGN is a WB affiliate, it does not transmit WB programming outside the Chicago area.

2 Comedy Central is a joint venture between Viacom and HBO/AOL Time Warner and is allocated to the company with the largest holdings (Viacom).

Lifetime is a joint venture between ABC/Walt Disney (50\%) and the Hearst Corp. $(50 \%)$ and is allocated to the company with the largest holdings (Walt Disney). 


\section{Vertical Integration and Media Regulation in the New Economy}

$4 \quad \mathrm{~A} \& \mathrm{E}$ and the History Channel are joint ventures of $\mathrm{ABC} /$ Walt Disney (37.5\%), the Hearst Corp. (37.5\%), and NBC/General Electric (25\%), and are allocated to the company with the largest holdings (Walt Disney).

BET is a joint venture of BET Holdings, Microsoft Corporation, News Corp., USA Networks, and Liberty Digital and is allocated to the company with the largest holdings (News Corp.).

Discovery Communications, which operates the Discovery Channel, TLC, and Animal Planet, is a privately held company owned by Liberty Media Corp. (49\%), Cox Communications, Advance/Newhouse, and founder John S. Hendricks. It is allocated to the company with the largest holdings (Liberty Media Corp.).

7 NBC owns $32.5 \%$ of PaxTV.

B USA Networks, Inc., is a corporation owned by Liberty Media Corp. (20\%), Universal (9\%), and the public $(71 \%)$. Because of the large percentage of public holdings, it is presumed to set price independently.

Ratings for cable networks are taken from Basic-Cable Prime-Time Ratings, BRANDWEEK, June 11, 2001, at SR20, and represent prime-time ratings for the top forty cable networks for the first quarter of 2001. Notably, this data does not include data for premium movie or home shopping channels.

Ratings for the broadcast networks are taken from Broadcast Watch, BROADCASTING \& CABLE, Apr. 2, 2001, at 25, and represent season-todate prime time ratings as of Mar. 25, 2001. Although the time periods are not directly comparable and prime time ratings may not be representative of viewership during other times of day, these numbers should provide an adequate basis for making a rough estimate of market concentration.

Ownership information is taken from WATERMAN \& WEISS, supra note 21 , at $24-32$, and was verified by visiting the networks' websites. In the absence of a clear majority owner, I attempted to make the most conservative assumption in terms of calculating HHIs by allocating the ratings to the player with the largest rating share. 
Appendix B. Revenue of Twenty-Five Largest

Television Networks, Projected 2000 Revenue

\begin{tabular}{|c|c|c|c|}
\hline Company/Network & $\begin{array}{l}\text { Revenue } \\
\text { ( } \$ \text { billion) }\end{array}$ & Company/Network & $\begin{array}{l}\text { Revenue } \\
\text { (\$ billion) }\end{array}$ \\
\hline Walt Disney Co. & & Llberty Media & \\
\hline $\mathrm{ABC}$ & 4.4 & QVC & 3.3 \\
\hline ESPN & 2.1 & Discovery Channel & 0.6 \\
\hline Disney Channel & 0.6 & Starz! & 0.4 \\
\hline Lifetime & 0.5 & TLC & $\underline{0.4}$ \\
\hline $\mathrm{A} \& \mathrm{E}$ & $\underline{0.5}$ & Total & 4.7 \\
\hline \multirow[t]{2}{*}{ Total } & 8.1 & & \\
\hline & & News Corp. & \\
\hline Viacom & & Fox & 1.8 \\
\hline CBS & 3.5 & Fox Sports Net & $\underline{0.6}$ \\
\hline Nickelodeon & 1.0 & Total & 2.4 \\
\hline Showtime & 0.9 & & \\
\hline MTV & $\underline{0.7}$ & USA Networks & \\
\hline \multirow[t]{2}{*}{ Total } & 6.1 & HSN & 1.5 \\
\hline & & USA Network & $\underline{0.8}$ \\
\hline General Electric & & Total & 2.3 \\
\hline NBC & 4.7 & & \\
\hline CNBC & $\underline{0.5}$ & Univision & 0.5 \\
\hline Total & 5.2 & & \\
\hline \multicolumn{4}{|l|}{ AOL Time Warner } \\
\hline $\mathrm{HBO}$ & 1.7 & & \\
\hline TNT & 1.2 & & \\
\hline TBS Superstation & 0.8 & & \\
\hline $\mathrm{CNN}$ & 0.8 & & \\
\hline Cinemax & $\underline{0.4}$ & & \\
\hline Total & 4.9 & & \\
\hline
\end{tabular}

Dollar revenue estimates are taken from 25 Top Television Networks, BROADCASTING \& CABLE, Nov. 27, 2000, at 54. They represent only the top twenty-five networks and include all revenue. Ownership attribution follows the approach taken in Appendix A. 